\title{
HISTORICALLY-INFORMED DEVELOPMENT IN THE CIVIC CENTER SOUTH AREA OF DOWNTOWN LOS ANGELES
}

\author{
A Thesis \\ presented to \\ the Faculty of California Polytechnic State University, \\ San Luis Obispo
}

In Partial Fulfillment

of the Requirements for the Degree

Master of City \& Regional Planning

by

John Daniel von Kerczek

June 2012 
(C) 2012

John Daniel von Kerczek

ALL RIGHTS RESERVED 
COMMITTEE MEMBERSHIP

TITLE:

AUTHOR:

DATE SUBMITTED:

COMMITTEE CHAIR:

COMMITTEE MEMBER:

COMMITTEE MEMBER:
Historically-informed development in the Civic Center South area of Downtown Los Angeles

John Daniel von Kerczek

June 2012
Hemalata C. Dandekar, Ph.D., Professor \& Department Head

Umut Toker, Ph.D., Associate Professor

Charlene Dekker, AIA, LEED, AP, Associate Principal, AECOM 


\begin{abstract}
Historically-informed development in the Civic Center South area of Downtown Los Angeles John Daniel von Kerczek
\end{abstract}

The site of today's Civic Center in Downtown Los Angeles evolved gradually over the course of over 150 years before being dramatically transformed in the early to mid 20th century. Understanding how this area evolved and was redeveloped can help guide efforts to restore physical and historical continuity throughout the area. Specifically, this historical understanding can assist in identifying key opportunity sites within the area, such as Civic Center South, and in setting urban design goals for new development. Research for this thesis included an analysis of the area's historic development and a review of its current conditions. The historical analysis examined how the study area initially developed and how it was subsequently transformed through redevelopment. The review of current conditions examined recent and proposed development in and around the Civic Center South site and recent policies and regulations that are guiding new development within Downtown Los Angeles. This study ultimately provides an overview of the historic development context of the north end of Downtown Los Angeles as well as a review of the developments and regulations influencing development within that area today. 


\section{ACKNOWLEDGEMENTS}

I would like to express my deep gratitude to my thesis committee chair, Professor and City and Regional Planning Department Head Hemalata Dandakar, and my committee members, Assistant Professor Umut Toker and Associate Principal Charlene Dekker of AECOM, for their guidance, support and useful critiques of this research work. I also wish to extend my gratitude to Professor Paul Wack and Lecturer Lisa Wise for their valuable assistance and feedback on key portions of this research.

I would also like to thank the faculty, staff, and my fellow classmates in the City and Regional Planning program at Cal Poly San Luis Obispo. And finally, I wish to thank my parents and family for their support and encouragement throughout my study.

The images used to illustrate Chapters 4 and 5 of this thesis were used with the permission of the USC Specialized Libraries and Archival Collections and the Los Angeles Public Library. Specific collections from the USC Digital Archives that were drawn upon included the California Historical Society/TICOR photographic collection (CHS), the Los Angeles Examiner photograph collection (Examiner), and the "Dick" Whittington collection (Whittington). 


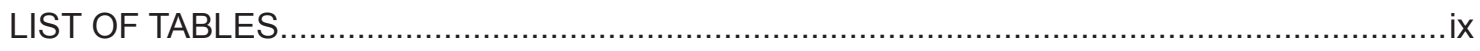

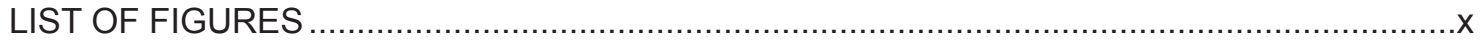

\section{CHAPTER}

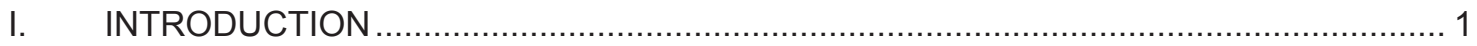

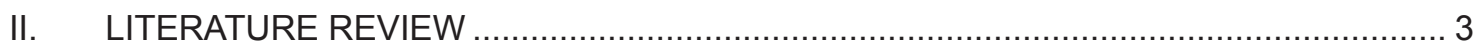

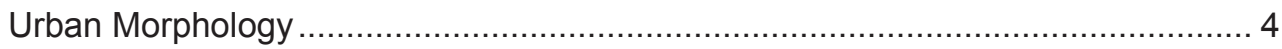

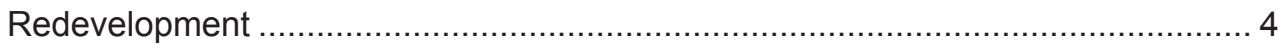

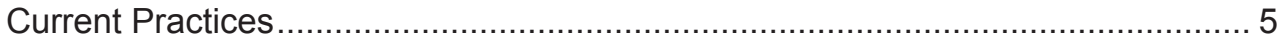

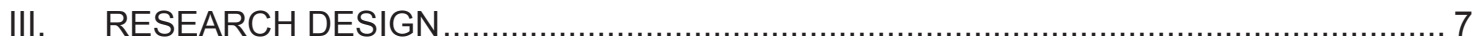

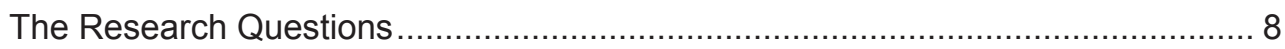

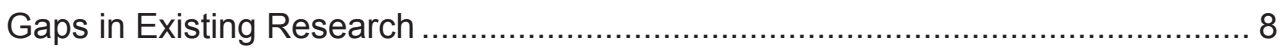

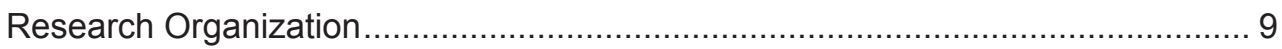

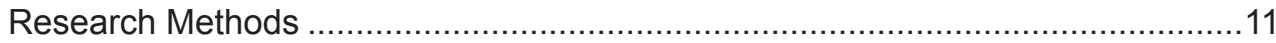

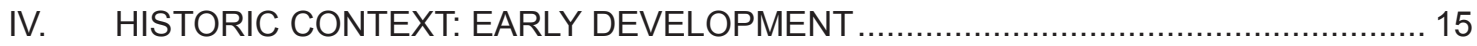

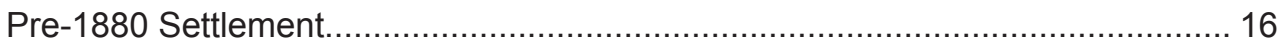

1880-1900: Railroads, Street Cars, and the First Land Boom............................ 21

Early 20th Century Developments......................................................... 36

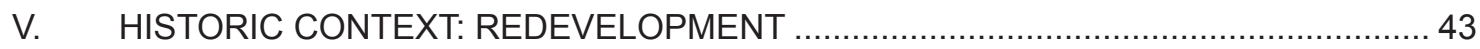

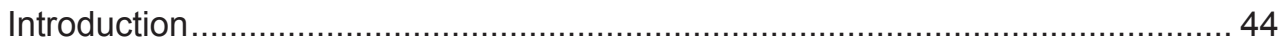

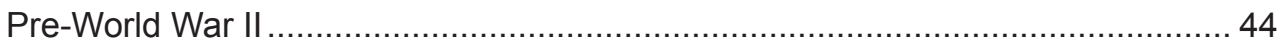

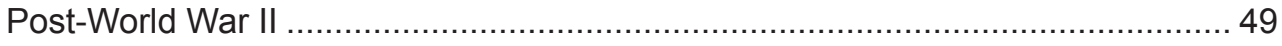


VI. CURRENT CONDITIONS: RECENT AND PROPOSED DEVELOPMENT ................... 53

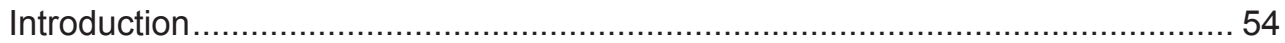

Large-Scale Redevelopment Proposals and Master Plans ............................... 55

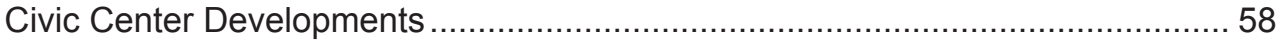

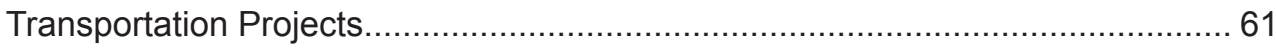

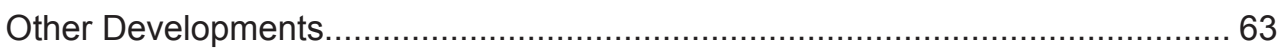

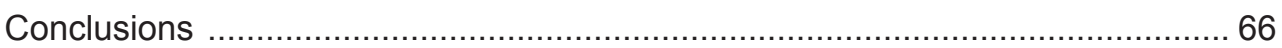

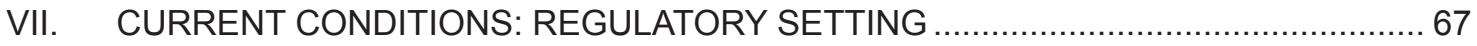

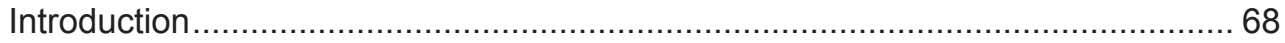

Development Site Location and Description.................................................. 68

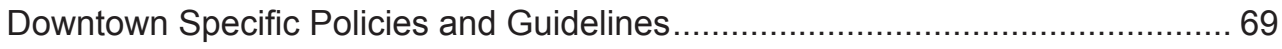

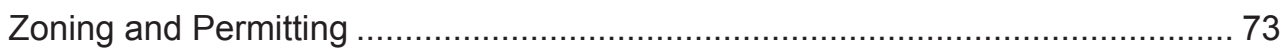

Redevelopment, Revitalization, and Business Improvement ............................ 75

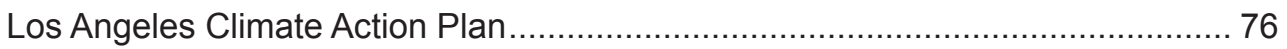

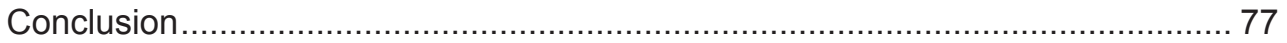

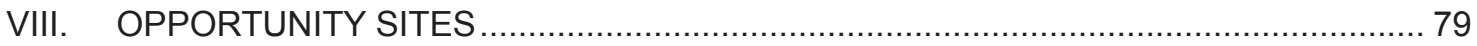

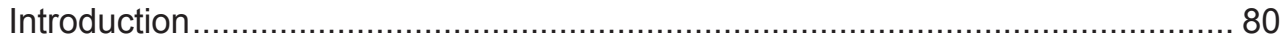

Site 1: Los Angeles Street and Main Street.................................................... 80

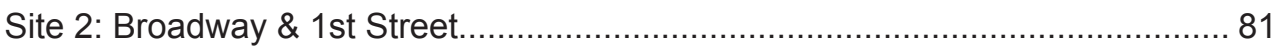

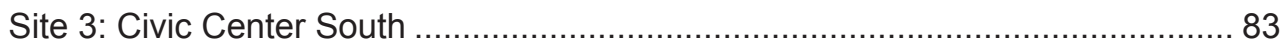




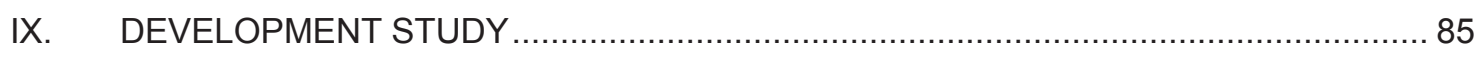

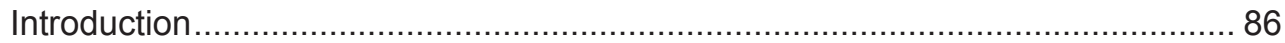

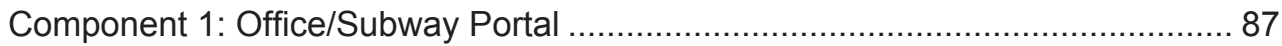

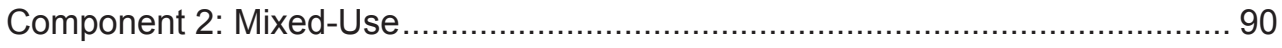

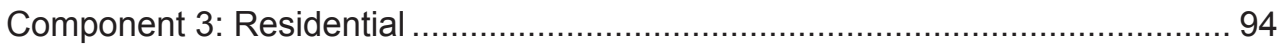

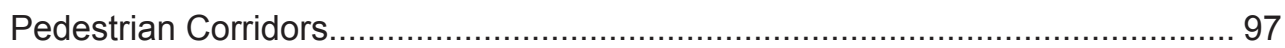

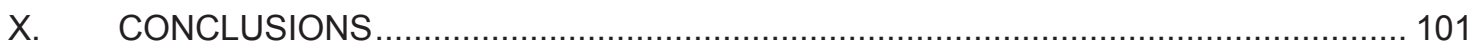

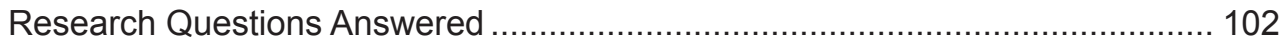

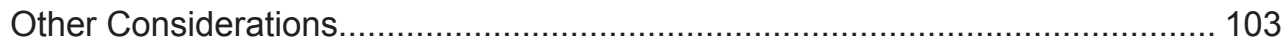

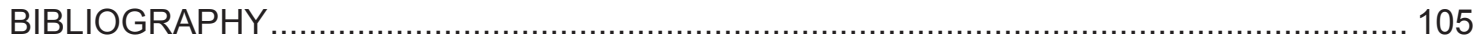

\section{APPENDICES}

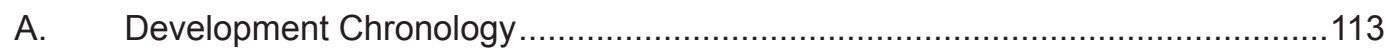

B. Comparative Population Growth of Mid-Western, Southwestern, and

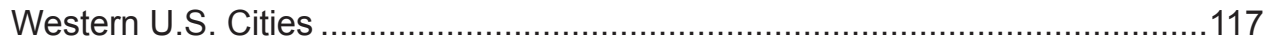

C. Zoning and Land Use Data for the Development Study Site ...........................119 
LIST OF TABLES

Table

Page

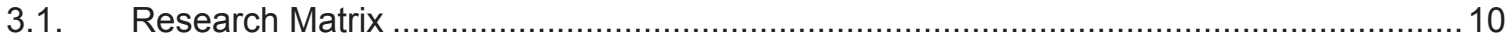




\section{LIST OF FIGURES}

Figure $\quad$ Page

3.1. Study Area and Development Example Site..............................................................

3.2. Development Study Site and surrounding context .................................................. 11

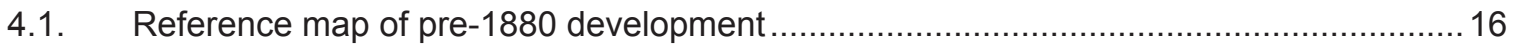

4.2. Section of E.O.C. Ord's first map of the city of Los Angeles, August 29, $1849 \ldots \ldots \ldots \ldots . . .18$

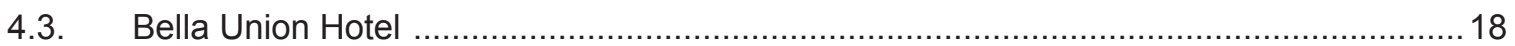

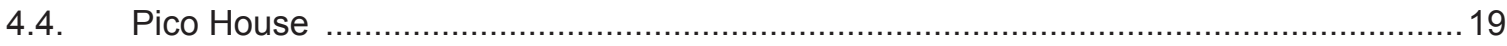

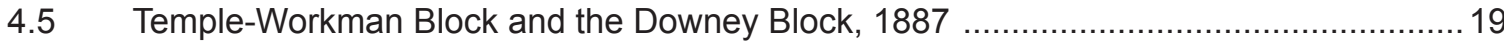

4.6. Looking north along Main Street from Temple Street towards the Baker Block, $1888 \quad \ldots .20$

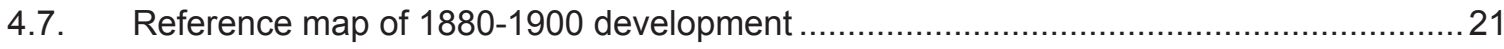

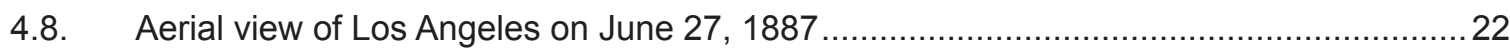

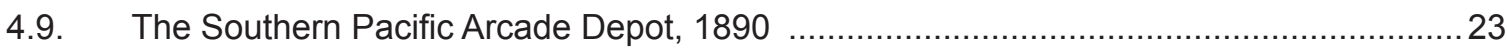

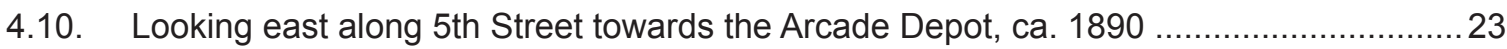

4.11. Santa Fe La Grande Depot with the First Street Viaduct visible to the left. ....................24

4.12. Second Street Cable Railway looking west 2nd and Broadway ...................................25

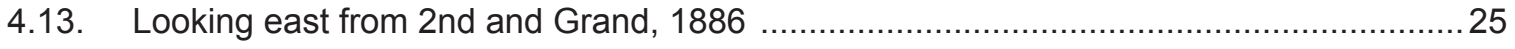

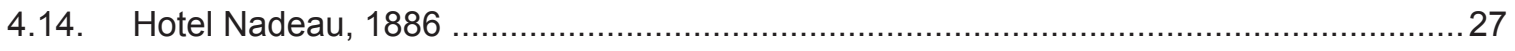

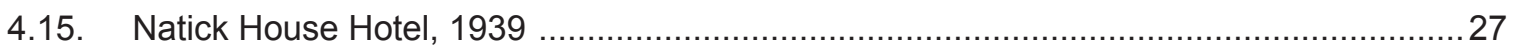

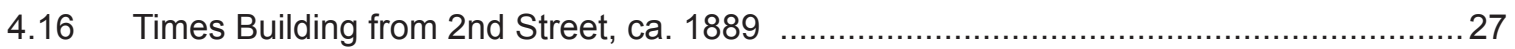

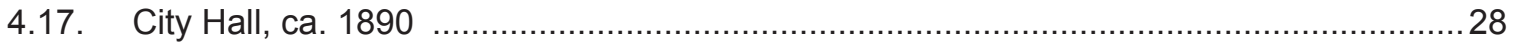

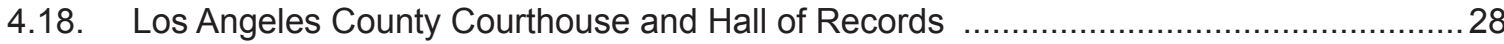

4.19. Looking north on Spring Street showing the Hollenbeck Hotel and the Bryson Block with the County Courthouse and the Phillips Block visible in the background .................2 28

4.20. Looking east along 3rd Street from Bunker Hill, showing City Hall, the Stimson

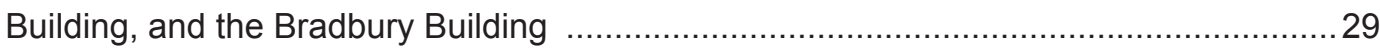

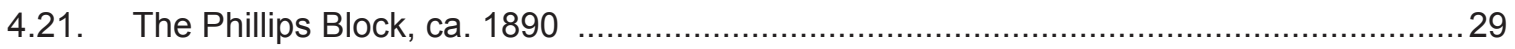




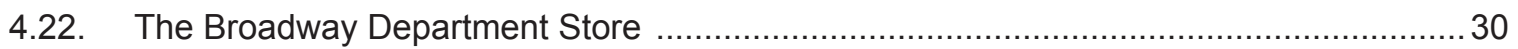

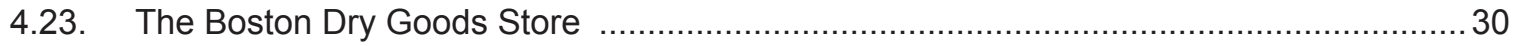

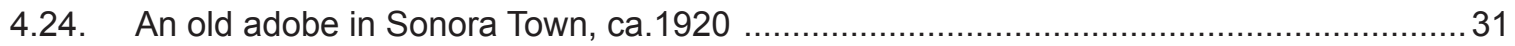

4.25. Looking west along Marchessault Street towards Alameda Street, ca. $1900 \ldots \ldots \ldots \ldots \ldots \ldots . . . . .32$

4.26. Looking north along Main Street from mid-block between 1st and 2nd Streets,

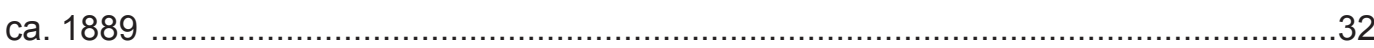

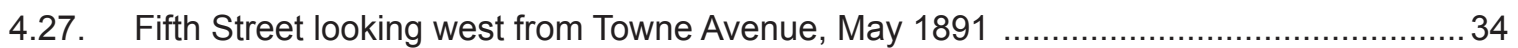

4.28. Looking west at the intersection of 3rd and Hill with Bunker Hill in the background, 1898

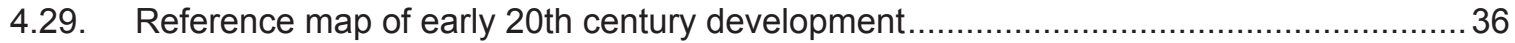

4.30. Spring Street, looking south from 3rd Street, Los Angeles, November 1898 .................37

4.31. Spring Street, looking south from 3rd Street, Los Angeles, November $1917 \ldots \ldots \ldots \ldots \ldots . . . . . . . . .37$

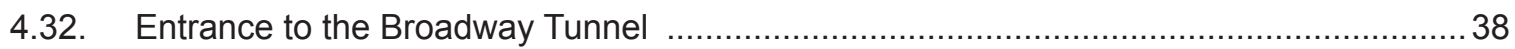

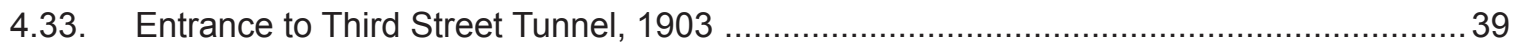

4.34. Map of the street railway lines of the Los Angeles street car system, December 1888 .. 40

4.35. Map of the Los Angeles street railway (streetcar) system, ca.1910 .............................40

4.36. The south portal of the Hill Street Tunnel under Court Hill from Hill and 1st Streets........40

4.37. The north portal of the Hill Street Tunnel under Court Hill from Hill and Temple Streets.. 40

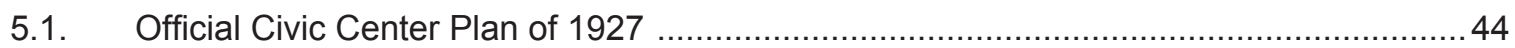

5.2. Proposed street openings and widenings in Downtown Los Angeles, from the 1924 Major Traffic Street Plan .45

5.3. Aerial view looking north along Main Street at the Civic Center area prior to construction of City Hall, December 7, 1925 46

5.4. Aerial view of the Civic Center showing the completed City and the California State Building under construction, August 22, 1931

5.5. Aerial view looking west at the Civic Center showing Spring Street extended north of Temple Street, land cleared for the Federal Courthouse, and 1st Street being widened . 47 
5.6. Area north of Temple Street prior to the extension of Spring Street

5.7. $\quad$ Area north of Temple Street after Spring Street has been extended 47

5.8. Aerial view looking west at the Civic Center showing the completed Federal Courthouse and 1st Street widened between Main Street and Broadway 48

5.9. Looking east along 1st Street from Hill Street prior to widening 48

5.10. Looking east along 1st Street from Hill Street after widening ...................................... 48

5.11. Aerial view of the four level interchange under construction ...................................... 49

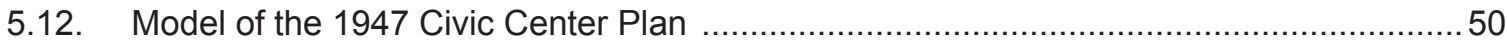

5.13. Aerial view looking southwest at the Civic Center showing land cleared for construction of the LAPD Headquarters 50

5.14. View west from City Hall of the north end of Bunker Hill prior to redevelopment. 51

5.15. View west from City Hall of the north end of Bunker Hill showing Court Hill cleared and the LA County Courthouse under construction, June 24, 1956 51

5.16. View looking northwest over the intersection of 1st and Broadway showing the construction of State Office Building No. 2 (foreground) and the LA County Hall of Administration (background), September 11, 1958 52

5.17. View west over City Hall showing the construction of City Hall East (foreground) and the Criminal Courts Building (behind City Hall), January 20, 1970 ...............................52

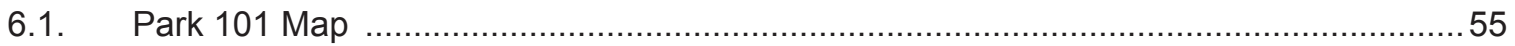

6.2. Park 101 in relation to Study Area and Development Study Site ...................................55

6.3. First Street Now! diagram showing treatment of 2nd Street.......................................56

6.4. Civic Crossroads and First Street Now! in relation to Study Area and Development Study Site .56

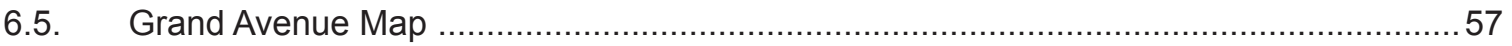

6.6. The Grand Project in relation to Study Area and Development Study Site .....................57

6.7. Civic Center developments in relation to Study Area and Development Study Site......... 58

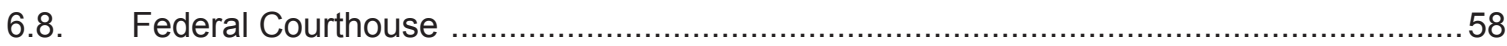


6.9. Regional Connector Transit Corridor Map

6.10. Diagram of Broadway and 2nd Street Station showing dual portal option (Top) and single portal option (Bottom)

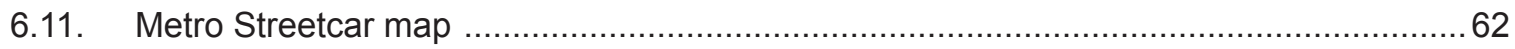

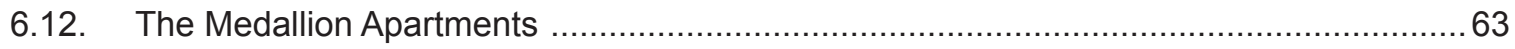

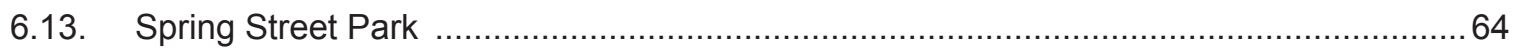

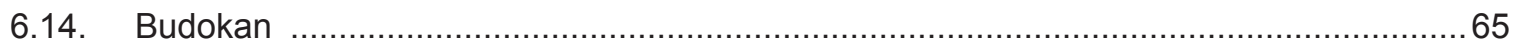

7.1. Map of districts subject to Downtown Los Angeles Design Guide policies. ...................68

7.2. Map of Downtown Neighborhoods and District, 1993 Downtown Strategic Plan ...........69

7.3. Historic Downtown Los Angeles Design Guidelines subject area. ............................... 71

7.4. Mid-block pedestrian pathway treatment, Historic Downtown Design Guidelines. .......... 71

7.5. Broadway Theater and Entertainment Design subject area. ...................................... 72

7.6. Generalized Land Use Map (left) and Floor Area Ratio Map (right), Center City

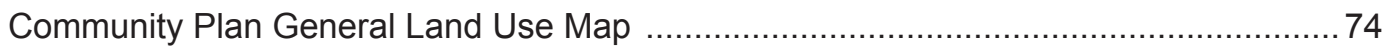

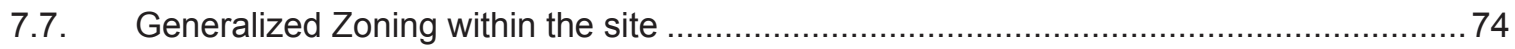

7.8. CRA/LA City Center Redevelopment Project Map. .................................................... 75

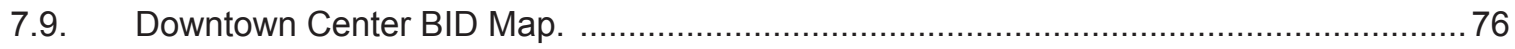

8.1. Opportunity Sites: (1) Los Angeles Street and Main Street, (2) Broadway and 1st

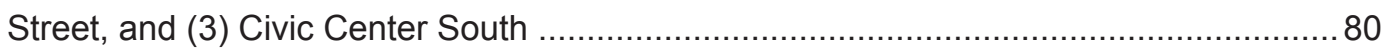

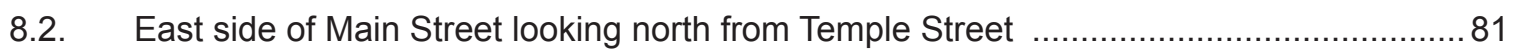

8.3. West side of Los Angeles Street looking north from Temple Street ............................. 81

8.4. East side of Los Angeles Street between Temple and 1st Streets showing the entrance to the Parker Center

8.5. Future site of the new Federal Courthouse, southwest corner of Broadway and 1st Street

8.6. Former site of the 1933 California State Office Building, northeast corner of Broadway and 1st Street 
8.7. Los Angeles County Law Library, northwest corner of Broadway and 1st Street

8.8. Los Angeles Times West Building, southeast corner of Broadway and 1st Street ..........82

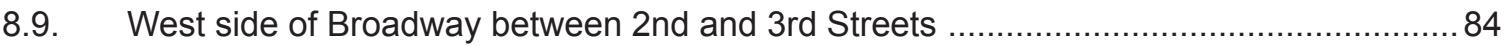

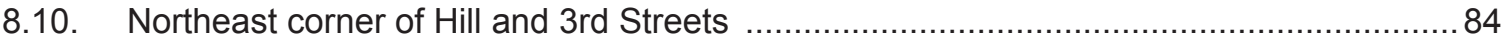

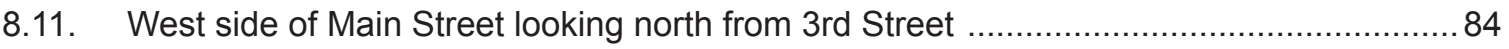

8.12. East side of Spring Street looking north from 3rd Street .............................................. 84

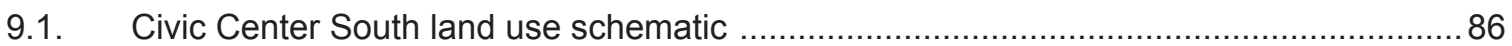

9.2. Proposed and available development sites around Civic Center South .......................... 86

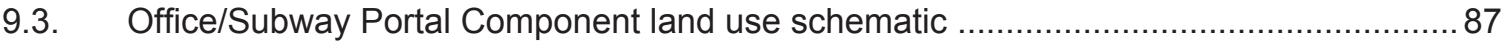

9.4. Proposed and available development sites near the Office/Subway Portal Component 87

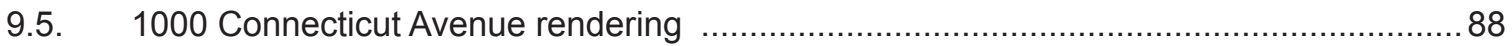

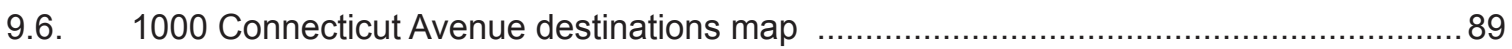

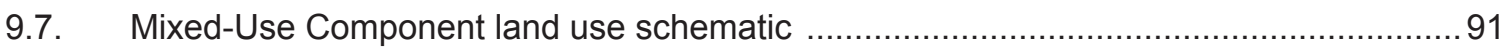

9.8. Proposed and available development sites near the Mixed-Use Component .................91

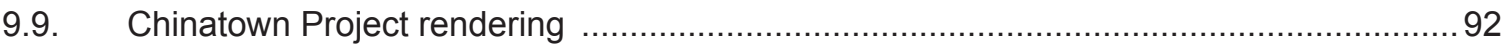

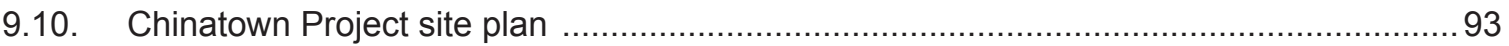

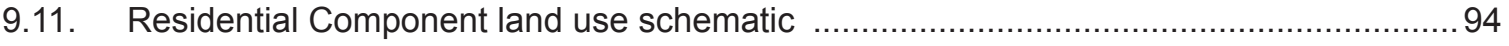

9.12. Proposed and available development sites near the Residential Component .................94

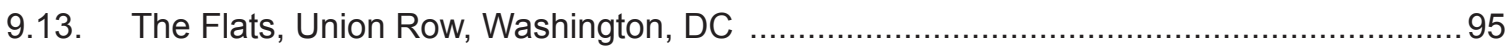

9.14. Facade differentiation, The Flats, Union Row, Washington, DC ...................................96

9.15. Facade differentiation, The Flats, Union Row, Washington, DC ….............................. 96

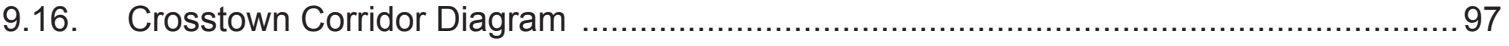

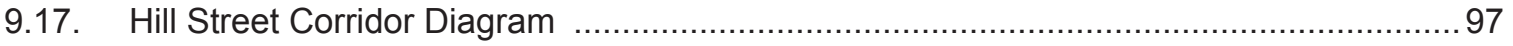

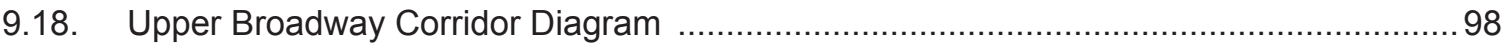

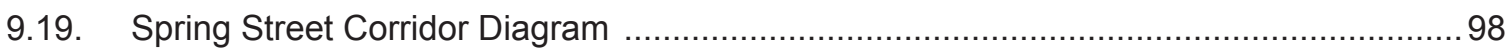

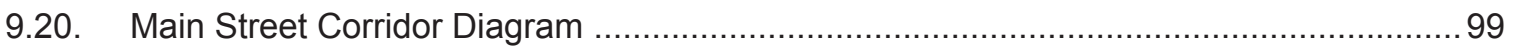


Chapter 1. Introduction 
Beginning in the 1920s, the oldest sections of Downtown Los Angeles, comprising its 19th century urban core, were cleared to make way for a new Civic Center and the Hollywood Freeway. Redevelopment was the product of a number of individual plans and projects executed under different levels of authority (city, county, state, and federal). Nonetheless, redevelopment resulted in the almost complete removal of the area's historical context and pedestrian scale. The original fine-grained urban environment accumulated over the preceding century and a half was wiped away, replaced by a single-use government administrative complex consisting of buildings occupying entire blocks.

Redevelopment dramatically changed the scale of the urban environment in the Civic Center and disrupted its physical and historical continuity with the surrounding architecture and urban fabric. However, recent development proposals and city policies have increasingly reflected the need to restore physical connectivity and historical continuity to the northern end of Downtown. These proposals and policies range in size and form, from large-scale interventions such as the Park 101 project and the Grand Avenue Project to strategic policy reforms such as the city's adaptive reuse ordinance, which has played a significant role in Downtown's revitalization and resurgence over the past two decades.

These projects and policies could potentially reestablish connectivity within the area and restore a sense of coherence and continuity to the currently fragmented urban environment. However, there lurks a danger that, by failing to acknowledge the area's previous history and patterns of development, these projects could exasperate the area's fragmentation rather than reinforce a sense of place that draws upon its past.

The purpose of this study is to determine how an understanding of Downtown Los Angeles' historical development patterns can guide new development and contemporary urban design and help in repairing or restoring urban continuity and a pedestrian scale in the Civic Center South area. This study will also explore how such historically-informed strategies can be pursued while also meeting the demands of current land use policies, economic imperatives, and urban design standards. 
Chapter 2. Literature Review 


\section{Urban Morphology}

Los Angeles has a well-established reputation as an "unplanned" city that grew haphazardly since its inception. However, as Kostof (1991) notes, "no city, however arbitrary its form may appear to us, can be said to be 'unplanned." He elaborates by stating that power, in the form of control of urban land, is the primary force shaping the design of the city. (p. 52)

In the case of the study area (and of Los Angeles in general), power has shifted repeatedly throughout its history of development. Formal planning in the area began with the Spanish colonists, who overlaid their settlement on a preexisting rancheria established by local indigenous Native American tribes. (Griswold del Castillo, 1979, p. 5) The urban morphology during the Spanish and Mexican periods was guided by the Laws of the Indies as well as the social, political, and economic circumstances of Los Angeles and Southern California during those periods. (Crouch \& Mundigo, 1977, pp. 410-1)

After California became part of the United States, control of the land shifted from the increasingly disenfranchised Californios [land owning Mexican elite] to newly arrived settlers from the east, who subdivided the land according to the imperatives of land speculation. (Crouch \& Mundigo, 1977, p. 414) As the city evolved throughout the remainder of the 19th century and into the 20th century, its form was shaped by explosive population growth, new transportation technologies, the social composition and organization of the city's populace, and the duel processes of suburbanization and center city decline.

\section{Redevelopment}

Redevelopment of what is now known as the Civic Center began in the mid-1920s. By the mid 1970s all the land within the Civic Center had been redeveloped and nearly all the buildings that existed prior to redevelopment had been removed. The bulk of redevelopment occurred within two time periods: a prewar period from 1925 to 1940 and a postwar period from 1949 to 1975. Pre-war redevelopment was intended to ease congestion within the city center and create a centralized government administrative complex to anchor Downtown as the region's hub. (Fogelson, 1967, pp. 250-1, 262) However, as Kostof (1991) notes, the design of civic centers in the US during this period often reflected other broader, unstated goals and ideals. Civic Centers 
were often designed to create monumental urban environments rooted in Baroque city planning. The embedded aesthetic and ideological assumptions of these monumental plans frequently dovetailed with those of the burgeoning modernist movement, which idealized a grand scale and the clarity of abstract order over the messy and seemingly chaotic urban environments it sought to replace. Civic Center design in the early 20th century was also informed by the values espoused by the sanitation and reform movements. (p. 217)

Redevelopment during the pre-war period and particularly the postwar period was increasingly motivated by the economic concept of blight, or declining property values. As Weiss (1980) explains:

In the 1920s and 30s, the market for developed land in the inner city was shrinking due to the movement of middle income people and industry to peripheral areas. Downtown property owners, including major financial institutions such as banks and insurance companies, industrial corporations with downtown office headquarters, commercial land developers, hotel owners, department store and retail store owners, newspaper publishers, major realtors and realty management companies, and trustees of private hospitals and universities feared that property values would plummet and their businesses would suffer. (p. 255)

Groth (1994) summarizes the negative unofficial intentions and consequences of urban renewal, stating, "[i]n most cities, renewal was racially biased; renewal often lined certain landholders' or contractors' pockets more than it should have; building the new downtown frequently became an exercise in personal empire building at the service of the downtown business elite. Urban renewal was also a period of hotel resident removal." (p. 273)

\section{Current Practices}

According to Cuff (2000), much of contemporary urban development and redevelopment reflects the conflation of three aspects of contemporary urbanism: scale, upheaval, and property. Scale is reflected throughout the development process, from initial land assembly to the final comprehensive design and the immense sizes of the projects. Large-scale projects in turn produce upheaval in the city's function and form, as the original built environment, which 
developed gradually over a long period of time, is replaced in a single sudden, convulsive act of large-scale redevelopment. Large-scale development also heightens the complexity of property issues and politics. As a result, this scale of development inevitably involves a wider range of interests, including local governments, financial institutions, other property owners, and various interest groups. The result of this conflation of scale, upheaval, and property is what Cuff refers to as a "convulsive urbanism," which is inherently unstable, disruptive, and discontinuous. (pp. 4-5) 
Chapter 3. Research Design 


\section{The Research Questions}

This study is intended to address the following research questions:

Can an understanding of Downtown Los Angeles' historical development patterns guide new development and contemporary urban design and help in repairing or restoring urban continuity and a pedestrian scale in the Civic Center South area? And if so, how can a strategy of urban repair and restoration be pursued while also meeting the demands of current land use policies, economic imperatives, and urban design standards?

\section{Gaps in Existing Research}

The literature review for this study revealed two gaps in research. The first gap in information relates specifically to the historic fabric of 19th century Downtown Los Angeles. Existing research is generally scattered throughout numerous sources and often lacks the detail, specificity, or comprehensiveness needed to create a coherent and unified picture of the built environment in this area of Downtown prior to redevelopment. The lack of an image of the area's original built environment makes it difficult to perceive how the area's remaining historic assets once fit together as part of a larger whole.

The second gap in research relates to research on the repair of historic fabric that has been disrupted due to urban renewal. While the effects of, and logic behind, urban renewal are well documented, less work has focused on strategies for correcting or mitigating the more egregious mistakes of the eras of urban renewal and early freeway construction. However, many cities are investigating or undertaking projects on a range of scales to repair their damaged urban fabric. Examples include the Boston's Big Dig, the restoration of the street network through the World Trade Center site in Lower Manhattan, and the Park 101 proposal to cap the freeway through Downtown Los Angeles. 


\section{Research Organization}

Based upon historical research, the boundaries of the study area were defined as Cesar Chavez Boulevard to the north, Hill Street and Grand Avenue to the west, 3rd and 4th Streets to the south, and Alameda Street to the east. (Figure 3.1) The area within these boundaries represents the extent of the city's central business district by the end of the 19th century. This area also includes land to the west that would later become part of the Civic Center and land to the east between the central business district and the city's pre-Union Station rail depots. Research was organized into three categories (historic context, current conditions, and opportunity sites), each with its own specific focus areas and research methods. (Table 3.1)

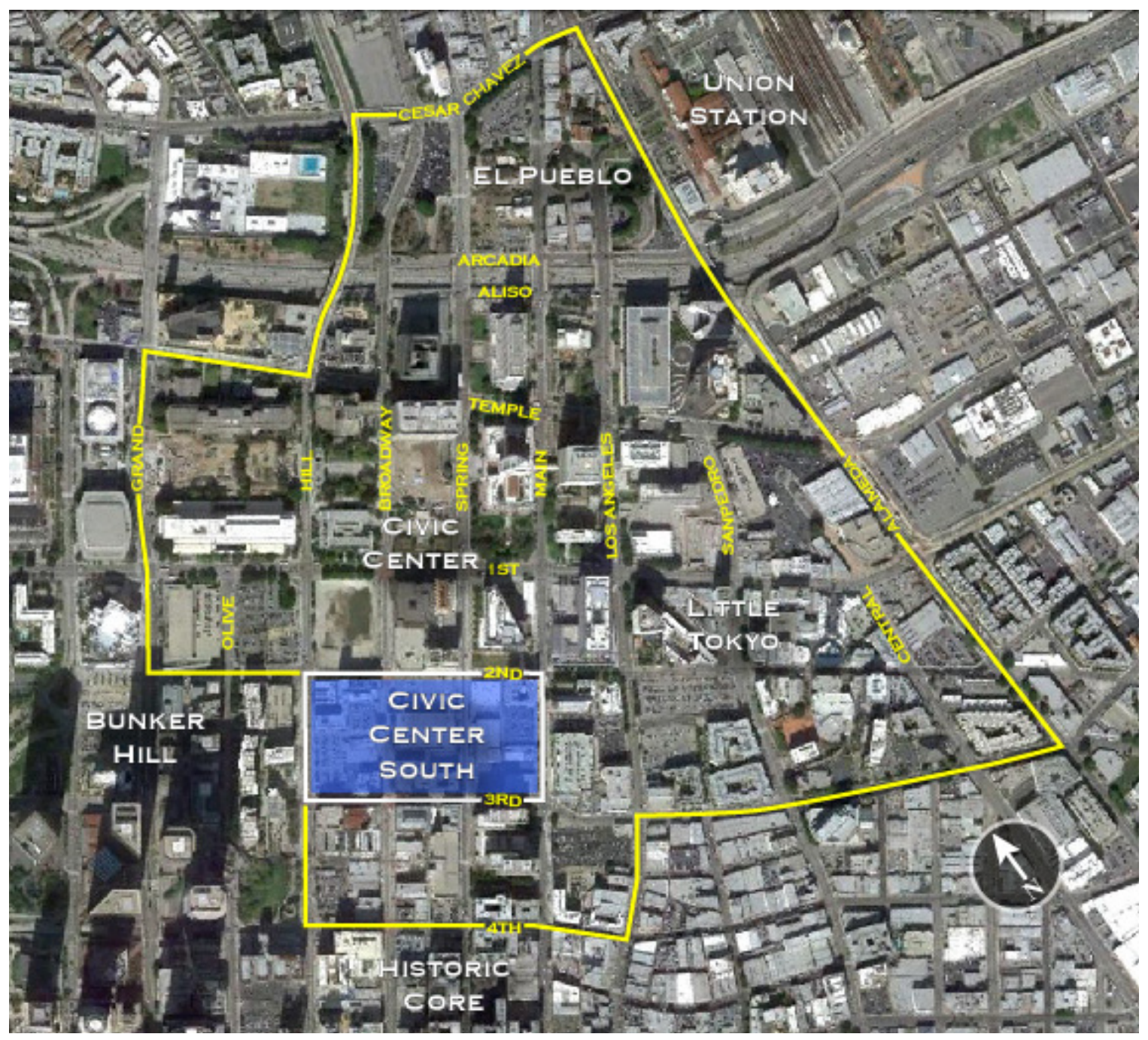

Figure 3.1. Study Area (Yellow) and Development Example Site (White and Blue) 
The historic context research is organized into two overarching periods: early development and redevelopment. The early development period encompasses the extent and character of development within the study area up to the 1920s. The redevelopment period encompases the series

\begin{tabular}{|c|c|c|}
\hline $\begin{array}{l}\text { RESEARCH } \\
\text { CATEGORY }\end{array}$ & FOCUS AREAS & METHODS \\
\hline \multirow{2}{*}{ Historic Context } & Early Development & \multirow{2}{*}{$\begin{array}{l}\text { Archival Photos; } \\
\text { Historic Research }\end{array}$} \\
\hline & Redevelopment & \\
\hline \multirow{2}{*}{ Current Conditions } & $\begin{array}{l}\text { Recent \& Proposed } \\
\text { Development }\end{array}$ & $\begin{array}{l}\text { Site Inventory; } \\
\text { Due Diligence }\end{array}$ \\
\hline & Regulatory Setting & Policy Review \\
\hline \multirow{2}{*}{ Opportunity Sites } & Opportunity Sites & \multirow{2}{*}{$\begin{array}{l}\text { Synthesis of } \\
\text { preceding research; } \\
\text { Case Studies }\end{array}$} \\
\hline & Development Study & \\
\hline
\end{tabular}

Table 3.1. Research Matrix of major redevelopment projects initiated between the mid-1920s and the mid-1970s. This study also examines the specific policies that enacted redevelopment, details the sequence of redevelopment, and identifies specifically what was demolished in the redevelopment process.

\section{Current Conditions}

The current conditions research is organized into two subcategories: recent and proposed development and regulatory setting. Recent and proposed development includes large-scale redevelopment proposals, new transportation infrastructure, strategic master plans and special district designations, historic preservation and adaptive reuse, infill development, and new civic and public facilities. Policies and regulations that are reviewed included zoning and land use designations, design guidelines and overlay zones, and ordinances related to parking and adaptive reuse. An analysis of the development study site is also included in the regulatory setting subcategory.

\section{Opportunity Sites}

To demonstrate how this study's findings can inform future development within the study area, three opportunity sites have been identified and urban design recommendations have been made for each of them. One of these sites, Civic Center South, was selected for more in depth evaluation and recommendations. This site was selected due to (a) its historic location and 


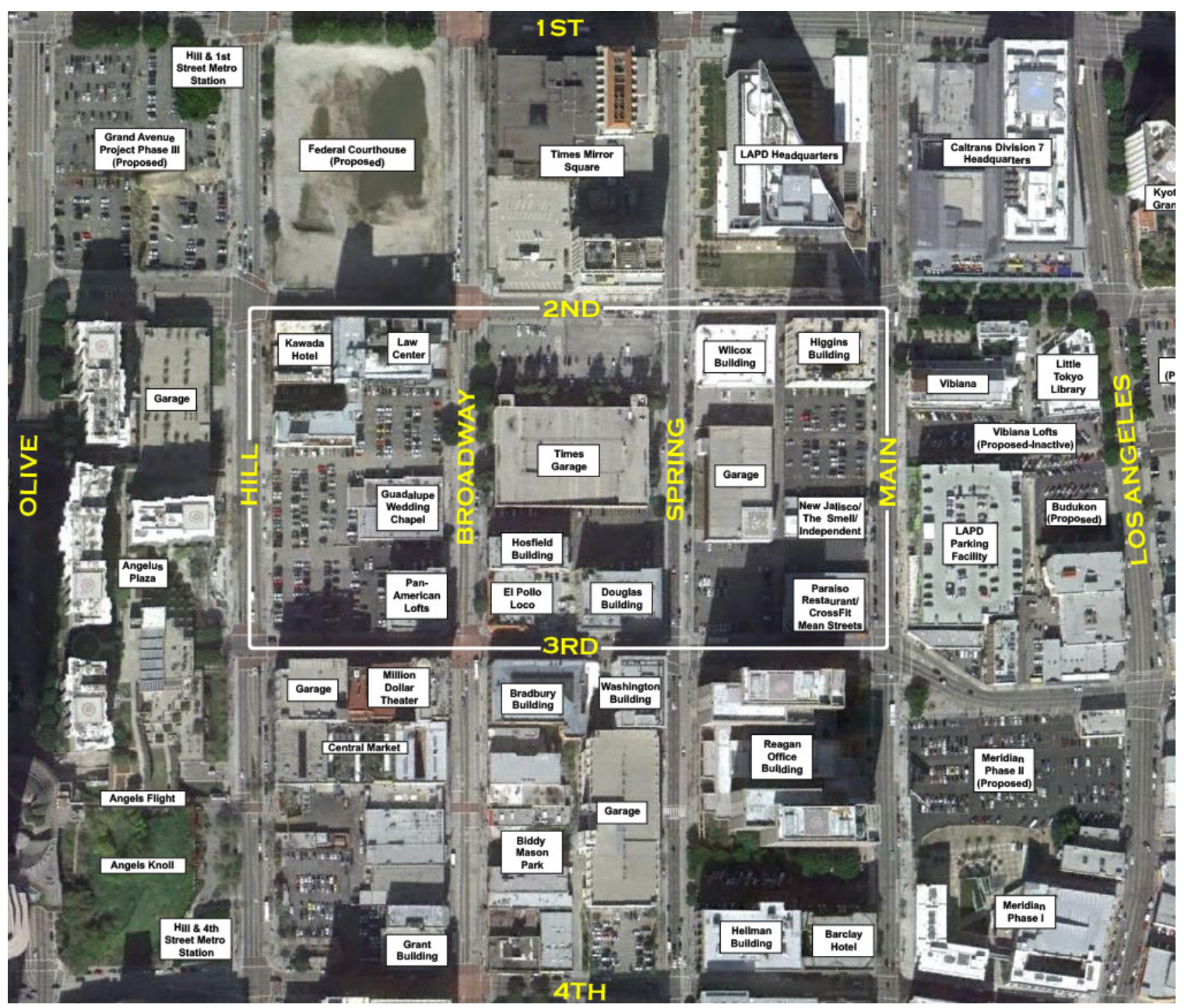

Figure 3.2. Development Study Site and surrounding context

function within the 19th century downtown's central business district, (b) the current deteriorated and vacant conditions within the site, (c) the absence of any currently active development plans for the land within the site, and (d) its potential as a "catalyst" for future revitalization throughout Downtown due to its strategic location within the study area and Downtown.

\section{Research Methods}

\section{Archival Photo Research}

To determine the historic context of the study area, archival photographs were collected, sorted, arranged, and cross-referenced according to location within the study area and time period. The primarily sources of these photographs were the USC Digital Archives and the Los Angeles Public Library Photo Collection, both of which make their content available through their websites 
(http://digitallibrary.usc.edu/search/controller/index.htm and http://www.lapl.org/catalog/photo_ collection_overview.html). Relevant photos were downloaded from the websites and uploaded to a Flickr account. Sets were created for most major streets in the study area and photos within each set were arranged according to their location along that street. Additional sets were created for specific locations and features, including the Temple Block area, Fort Moore Hill, Court Hill, the Union Station area, and North Spring Street. Sets were also created for historic aerial photos and historic maps of the area.

\section{Historical Research}

Additional historical research was conducted to provide greater dimension to the photographic research. The historical research included the literature detailed above, genealogical studies of local commercial enterprises and prominent local historical figures, building and development data, sociological research on segments of the city's early population, and population statistics for Los Angeles and other comparable cities. Relevant data was entered into an excel workbook containing spreadsheets that show: the chronology of individual building construction (sorted by street location and by building function/use); a timeline of railroad, street railway, and building construction; population growth statistics for major US cities that experienced comparable growth patterns; and a ranking of incorporated cities in Los Angeles County by population and by decade.

Site Inventory, Policy Review, and Due Diligence

Four site visits were performed between December 2010 and April 2012, during which an extensive photographic record of the study area and development study site was created. This record was used for comparison with the archival photos and to establish an inventory of existing conditions. Land use and existing business data were also collected at this time and entered into an Excel database.

A thorough review of land use and zoning policies affecting the study area was conducted. This review became part of a larger Due Diligence report that included additional information about the study area, such as physical conditions, site access and traffic, utilities, jurisdictions, and public safety. The parcel data and zoning information were then entered into an Excel database. 
Some market analysis was also performed, though further research will be needed to determine the financial feasibility of specific development recommendations. Informal conversations with members of the City's planning staff were also conducted. The policy review was also informed by presentations at the 2012 conference of the American Planning Association, including a session about the City's Adaptive Reuse Ordinance and its contribution to Downtown's resurgence.

\section{Case Studies}

Three cases studies of contemporary infill development accompany the development study to illustrate specific design recommendations and to provide examples of similar projects that have been proposed or constructed in comparable settings. Each case study represents an example of a specific project type represented in the development study, including a mixed-use project incorporating a pedestrian passageway, a Class A office building, and urban-scaled residential infill. 
Chapter 4. Historic Context: Early Development 


\section{Pre-1880 Settlement}

Prior to 1880, the development of Los Angeles occurred within two eras: the Spanish and Mexican era and the early U.S. era. Development during the Spanish and Mexican era was concentrated around the Plaza. Early development was guided primarily by the Spanish Laws of the Indies and the rural economy was organized initially around the Mission and later around the Mexican elites of the Rancho system (known as Californios). The transfer of control of the city to the US in 1848 ushered in an era of cattle ranching and land speculation. During this period, a new business district emerged at the convergence of Main, Spring, and Temple Streets, replacing the Plaza as the center of the town.

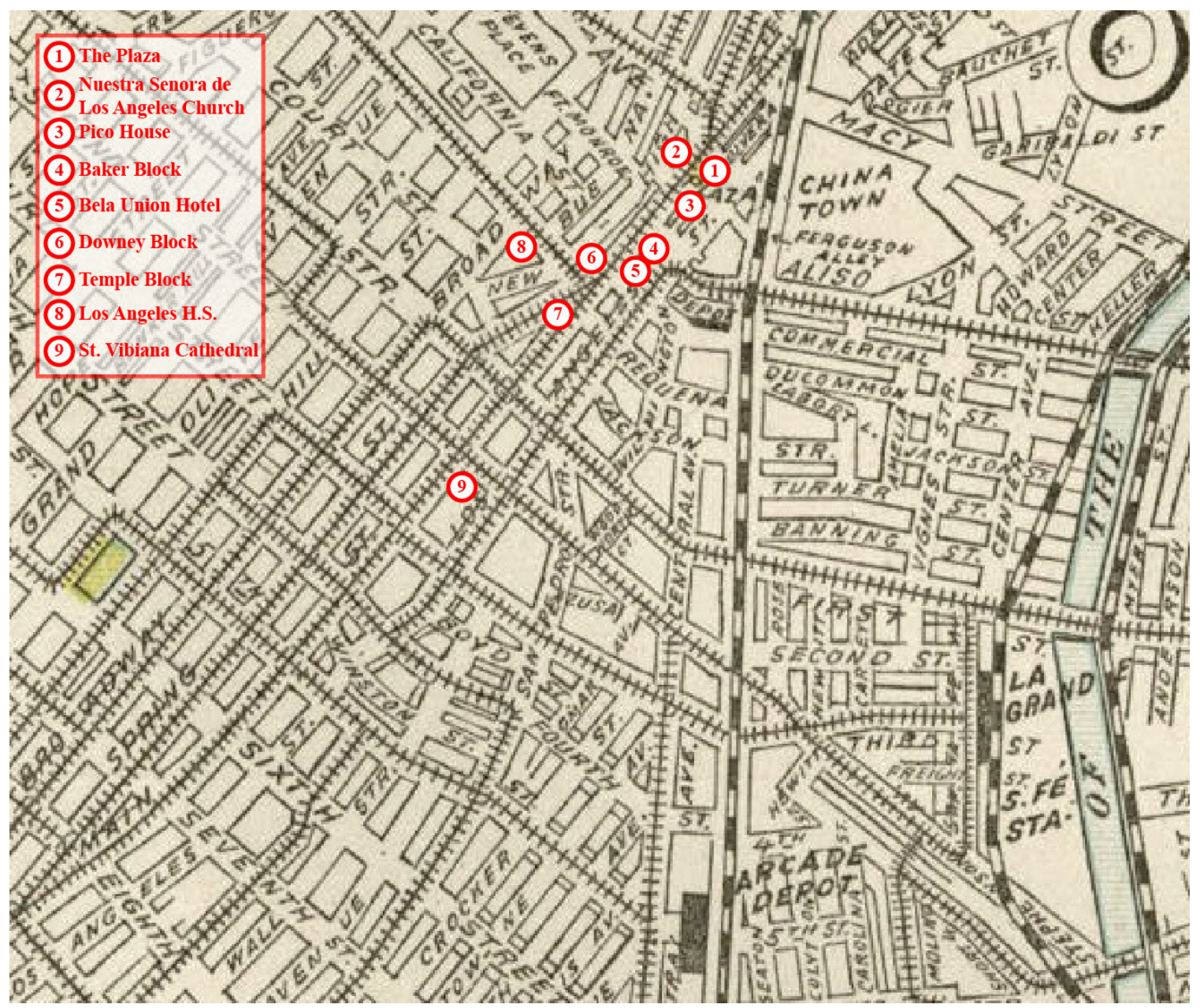

Figure 4.1. Reference map of pre-1880 development (Base Map: CHS) 
Spanish and Mexican Era (1781-1850)

El Pueblo de Nuestra Senora la Reina de Los Angeles was founded in 1781 by the Spanish Governor of the Californias Felipe de Neve. In selecting a site for the pueblo, the settlers followed the precedent established by Spanish settlers in New Mexico, Arizona, and Texas and chose a site near an established Indian village, in this case the rancheria of the Yang-na people on the west bank of the Rio Porciuncula. This site was chosen to ensure the presence of water, fertile land, and game, as well as a ready source of labor and women. (Griswold del Castillo, 1979, p. 5)

The inland location reflected the dictates of the Laws of the Indies, which reasoned that settlements located away from the coast would be protected from the unhealthful effects of swamps and from pirating. (Moule \& Polyzoides, 2005, p. 6) The Laws of the Indies also guided the layout of the Pueblo and the division of building lots and surrounding agricultural land (Crouch \& Mundigo, 1977, pp. 410-1). However, when the Rio Porciuncula flooded in 1815, the settlers were forced to relocate to the higher ground of today's Plaza. The new plaza was irregular in its dimensions due to its having to conform to already established property lines. The existing church of Nuestra Senora de Los Angeles was laid out at this time in its present location. (Moule \& Polyzoides, 2005, p. 6) Otherwise, the physical form of the pueblo changed little throughout the remainder of the pre-American period.

US Era (1850-1880)

\section{Political and Economic Transition}

With the signing of the Treaty of Guadalupe Hidalgo in 1848, Mexico ceded Alta California to the United States as part of the negotiations ending the Mexican-American war. (Treaty of Guadalupe Hidalgo, n.d.) Shortly thereafter, the new American Governor of the territory sent Lt. Edward Ord to survey and subdivide Los Angeles to facilitate the sale of land in the city. The resulting map became the new plan for the city. (Figure 4.2) (Crouch \& Mundigo, 1977, p 414)

According to Griswold del Castillo (1979), "During the American era, the pueblo of Los Angeles began to experience the problems and benefits associated with rapid modernization. The development of small-scale industry, intensive commercial farming, and technological innovation 


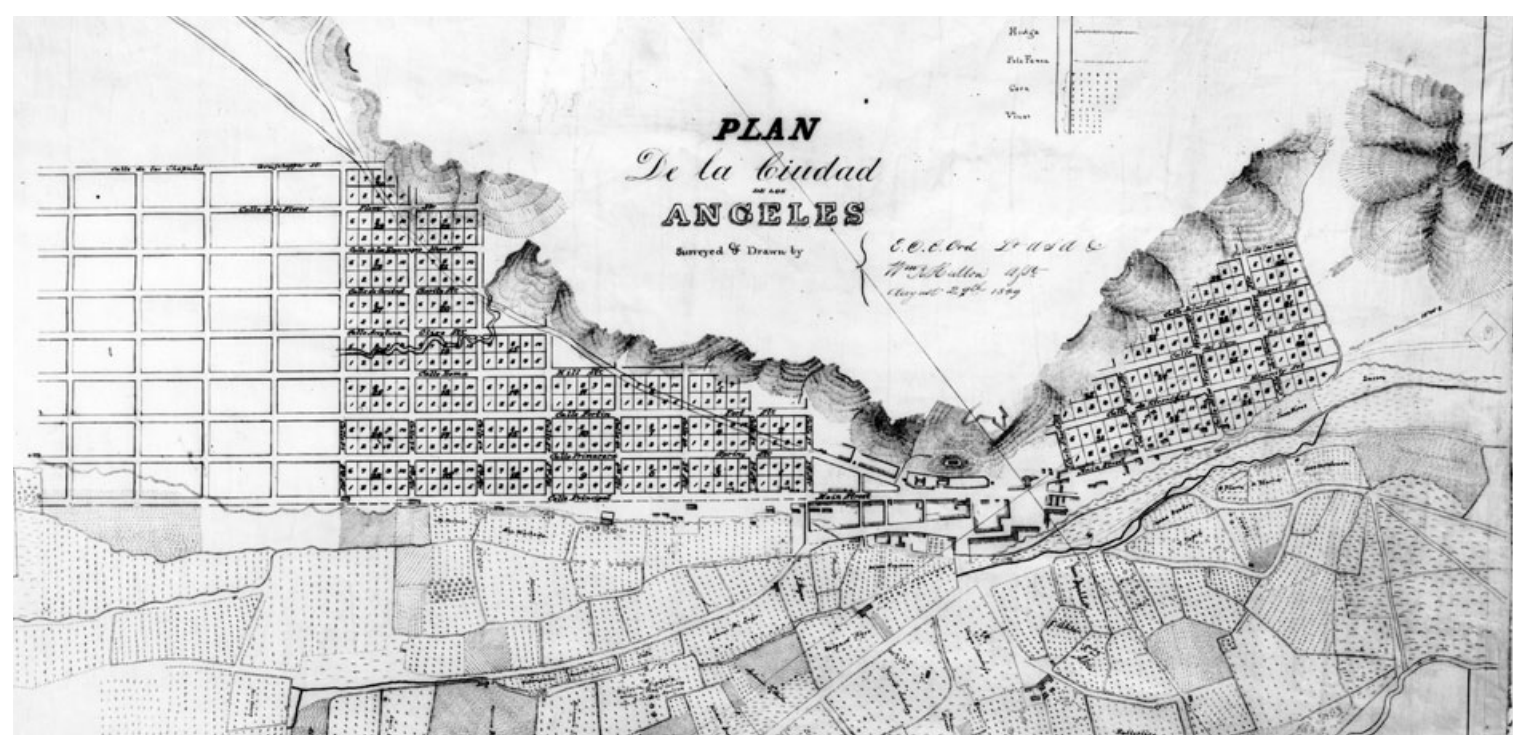

Figure 4.2. Section of E.O.C. Ord's first map of the city of Los Angeles, August 29, 1849 (CHS)

introduced a new kind of urban society at odds with the traditional Californio way of life." (p.

32) The city experienced its first cattle-driven boom in the early 1850 s and 60 s, fueled by the Gold Rush occurring in the north. In the wake of the cattle bust of 1863-4, city leaders turned their attention to improving the city by extending water mains, constructing street railway lines, developing public utilities, and subdividing land for sale and development (Fogelson, 1967, p. 42). The city also competed against San Diego to be the terminus of the second transcontinental railroad. With the Southern Pacific's completion of that transcontinental link in 1881, Los Angeles secured its role as the region's dominant metropolis. (p. 43)

\section{The Emerging American City}

During this period, the city's physical form and appearance began to change. New arrivals from the east built prefabricated wood houses south of the Pueblo and commercial buildings of brick and corrugated iron along Main and Los Angeles Streets. Los Angeles' first hotel, the Bella Union, was located on North Main Street at the site of today's Los Angeles Mall. (Figure 4.3) Other hotels soon joined the Bella Union, including the Lafayette (aka Cosmopolitan/St.

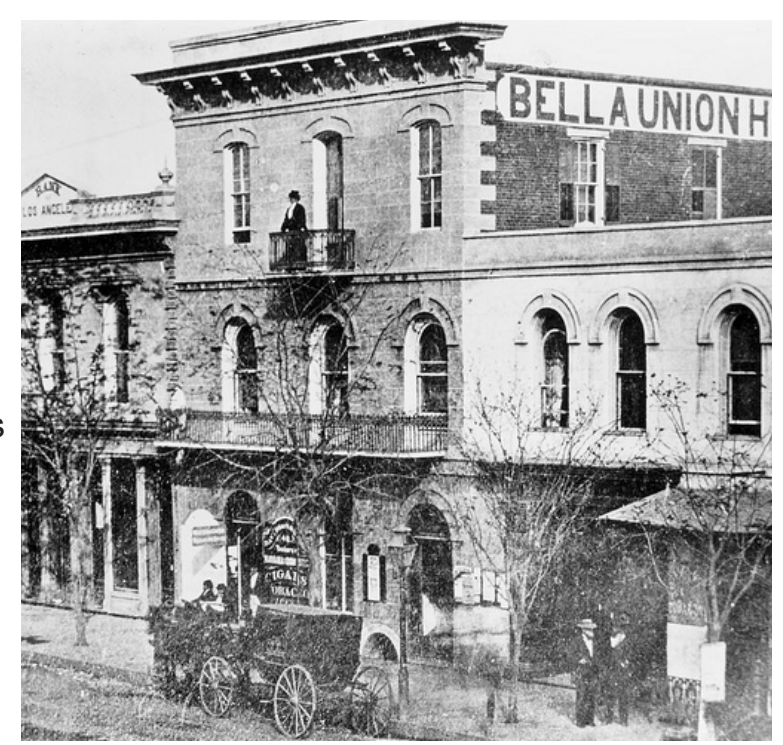

Figure 4.3. Bella Union Hotel (CHS) 


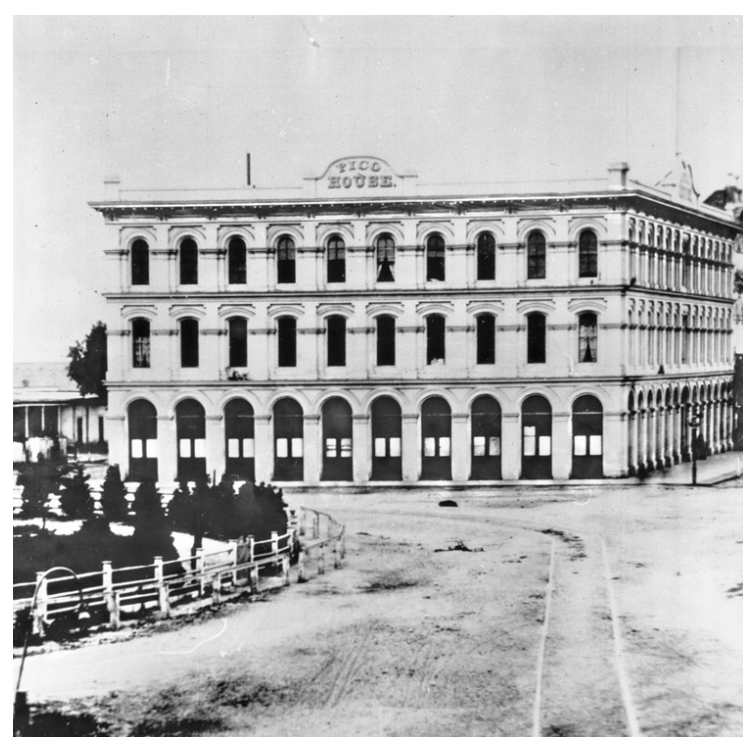

Figure 4.4. Pico House (CHS)
Elmo), the US Hotel (1863), the Grand Central, the White House (1870), and the Pico House (1870). Of these, only the Pico House remains standing today. (Figure 4.4) This first generation of Los Angeles hotels built prior to 1880 were clustered around the plaza and the intersection of Main, Spring, and Temple Streets. (McCann, et al., 2008, p. 9)

The city's first business block was the Arcadia Block, built in 1858 at the southwest corner of Los Angeles and Arcadia Streets. It was

followed by three of the most important business buildings of the city's early American years. In 1858, a new courthouse was built on what became known as the Temple Block, which was built by and named after John Temple, a prominent local businessman. (Crouch \& Mundigo, 1977, p 416). The Temple Block became a fixture of the local business district in the late 1800s, and in 1871, an addition called the Temple-Workman Block was built at the convergence of Main, Spring, and Temple Streets. (Figure 4.5) (Stargel \& Stargel, 2009, p. 43) The second important business building was the Downey Block, which was constructed in 1869 on the NW corner of Spring and Temple Streets. It was built by former California Governor John Downey and served as the original home of the Los Angeles Times and the B.F. Coulter's Dry Goods Store.

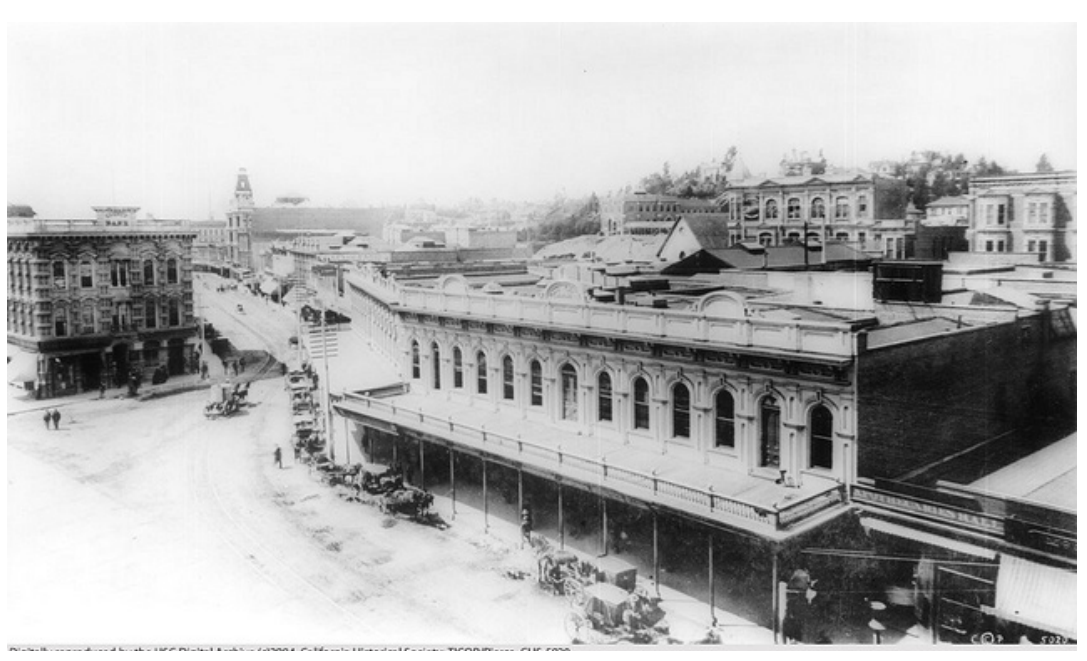

Figure 4.5 Temple-Workman Block and the Downey Block, 1887 (CHS) (p. 44) The Baker Block (Figure 4.6), built in 1877 on the opposite side of Main Street north of the Downey Block, was the third important business building and also the city's first modern office building. (p. 37) 


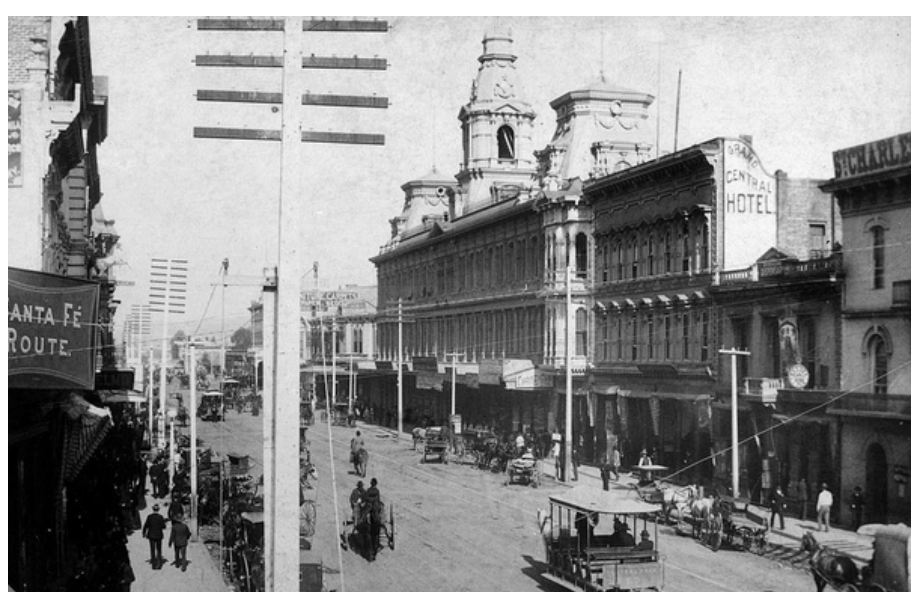

Figure 4.6. Looking north along Main Street from Temple Street towards the Baker Block, 1888 (CHS)
Other important buildings constructed during this period include: the Pelanconi House (1857), the Masonic Hall (1858), and the Merced Theater (1870), which are now part of El Pueblo de Los Angeles Historical Monument; St Vibiana Cathedral at 2nd and Broadway (1876); and Los Angeles High School (1873-5), originally built atop Poundcake Hill at Temple \& Broadway, which would become the site of the County Courthouse in 1891. (City of Los Angeles, El Pueblo de Los Angeles Historic Monument, 2011) 
1880-1900: Railroads, Streetcars, and the First Land Boom

The arrival of direct transcontinental railroad connections to the east in the 1880 s triggered a frenzy of land speculation and an expansion of the city and its downtown. During this period, the urban core expanded southward and westward and the center of the Downtown shifted from the Temple Block area to the area around 2nd and Spring Streets. By the end of this period, patterns of commercial and residential dispersal and decentralization began to emerge. These patterns would continue and accelerate in the next century. This section explores the physical and social context in which development occurred during this period, how Downtown's emerging form and functions were manifested in the city's built environment, and how residential development reflected the growing city's social composition and divisions.

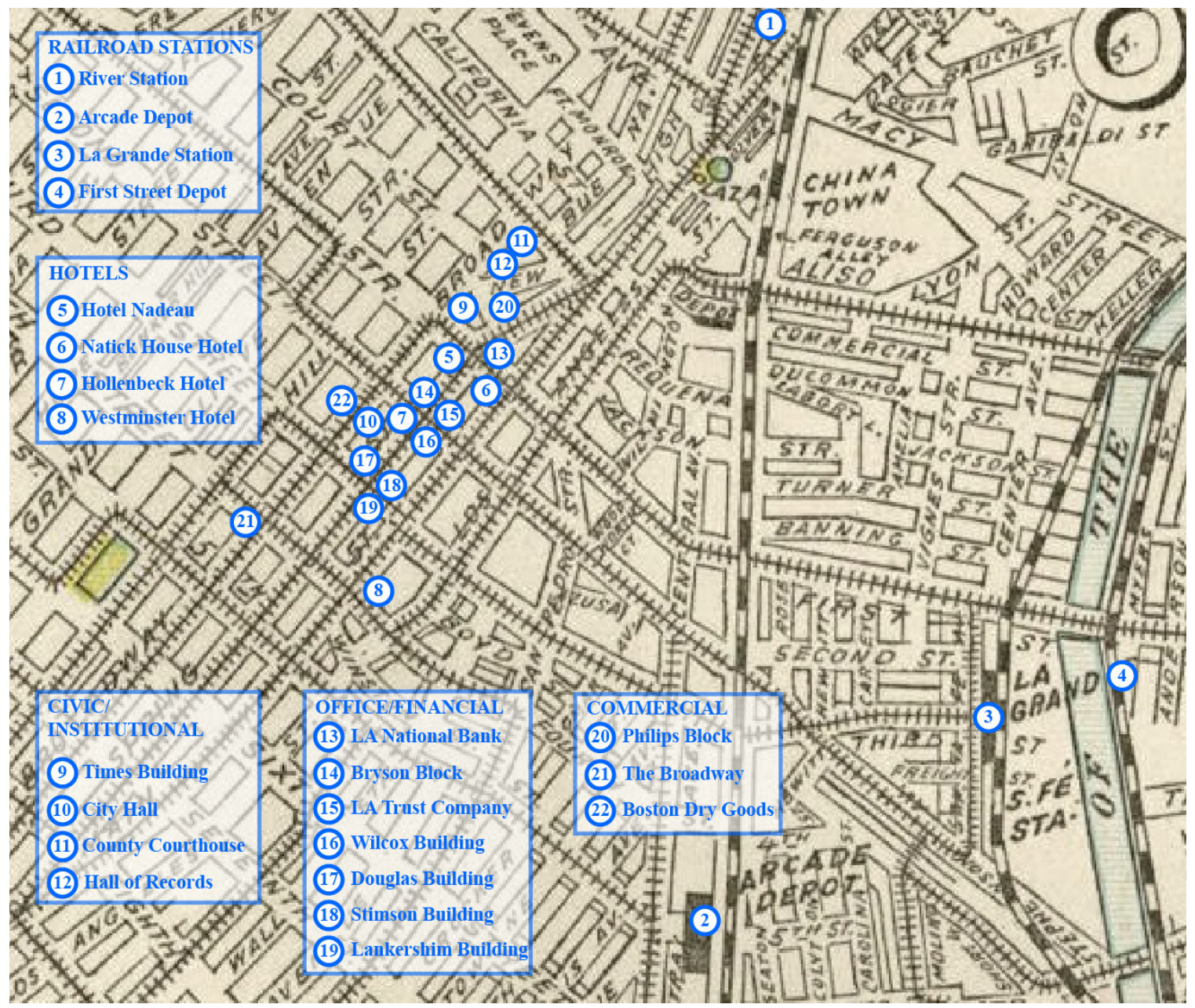

Figure 4.7. Reference map of 1880-1900 development (Base Map: CHS) 
After the arrival of the railroads, the area south of 1st Street emerged as the dominant center of downtown Los Angeles, eclipsing the primacy of the Temple Block area as the hub of business activity and the city's most fashionable hotels. According to Fogelson, by 1898 the center of the business district had shifted to the area around 2nd and Spring Streets. This shift reflected the topographical constraints the city's setting, the location of new railroad stations, and the expansion of the city's streetcar network.

\section{Topography and Street Network}

Longstreth (1997) summarizes the geographical constraints that shaped Downtown Los Angeles in the late 19th and early 20th century.

The downtown that emerged during the late nineteenth century was configured like the neck of an hourglass, bounded to the east and northeast by lowlands and railroad tracks and to the immediate west by the precipitous slopes of Bunker Hill, which extended south to Fifth Street. [Fig. 4.8] Expansion to the north would have to overcome a narrow, irregular street pattern and rolling terrain. To the south and southwest, on

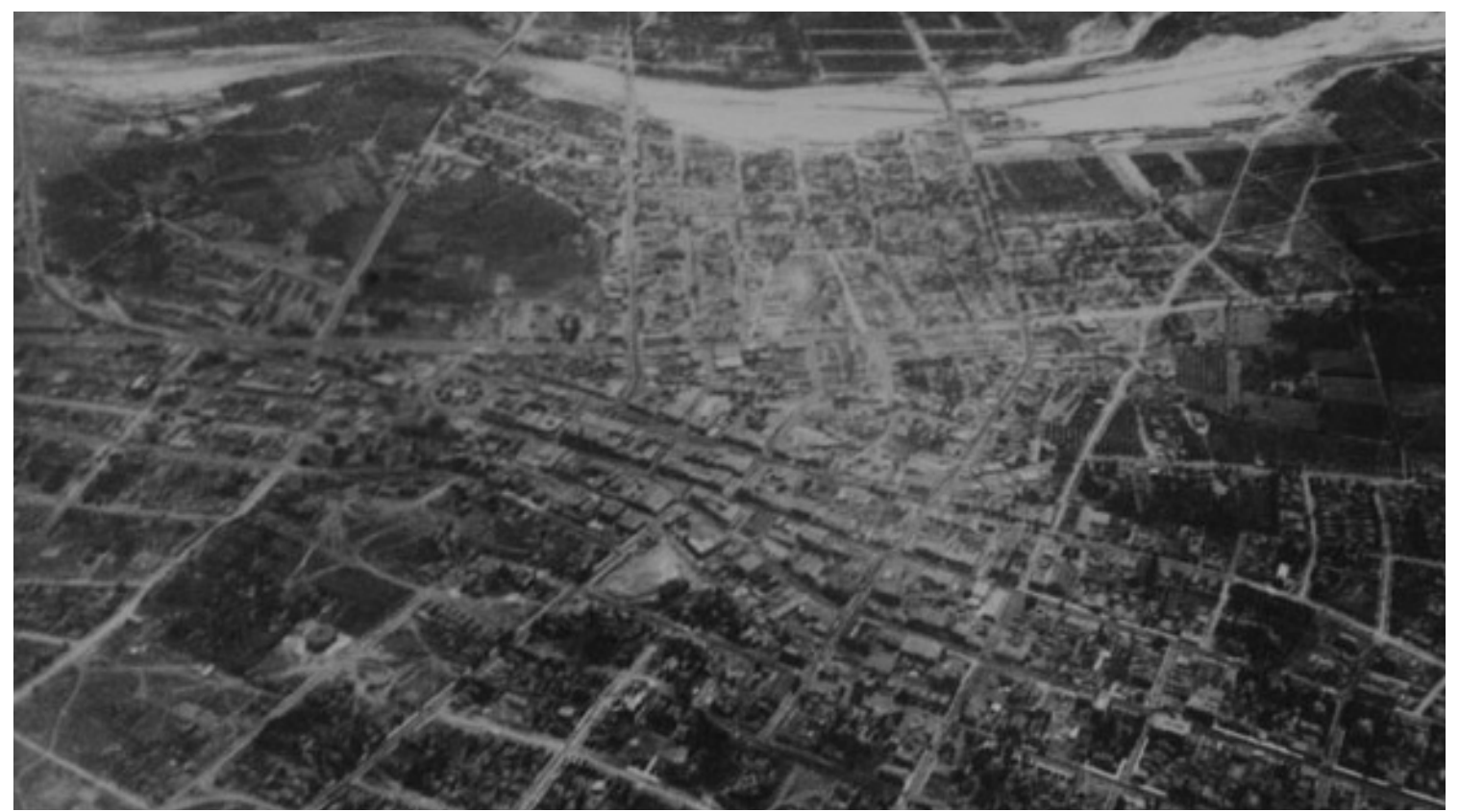

Figure 4.8. Aerial view of Los Angeles on June 27, 1887 (Los Angeles Public Library) 
the other hand, the existing grid of streets was straighter and wider, the land nearly flat. These distinctions continued for a considerable distance: hilly terrain lay to the north and northwest of the established city while seemingly limitless flatlands extended in a broad arc from south to west. After 1900, the first great thrust of residential development occurred within this latter sphere, where the terrain enabled lower costs for the construction of houses and, most importantly, of streetcar lines. Barring unusual circumstances, downtown was likely to grow in the same direction as the city itself. (p. 24)

\section{$\underline{\text { Railroad Stations }}$}

The location of railroad stations spurred the southwestward expansion of the business district and contributed an additional morphological element downtown Los Angeles's urban form. The Southern Pacific Railroad first reached Los Angeles from San Francisco in 1876. By 1881, the Southern Pacific completed a transcontinental link directly to Los Angeles. Its terminus at this time was a depot north of downtown in the area now known as the Cornfields. In 1888, the Railroad constructed its Arcade Depot at 5th Street and Central Avenue to replace its original station. (Figure 4.9)

The Arcade Depot was constructed on what was then known as the Wolfskill tract. Because of the large amount of open farmland in the Wolfskill tract and the placement of the Arcade Depot's location midway between the downtown and the river, this area developed rapidly, following the development pattern of other new railroad towns throughout the western US. (Figure 4.10) According to Van Ophem (2010), "From 1850 to 1910, these new towns appeared across the nation. In the West, where few cities had existed before, they became the fabric of the settlement
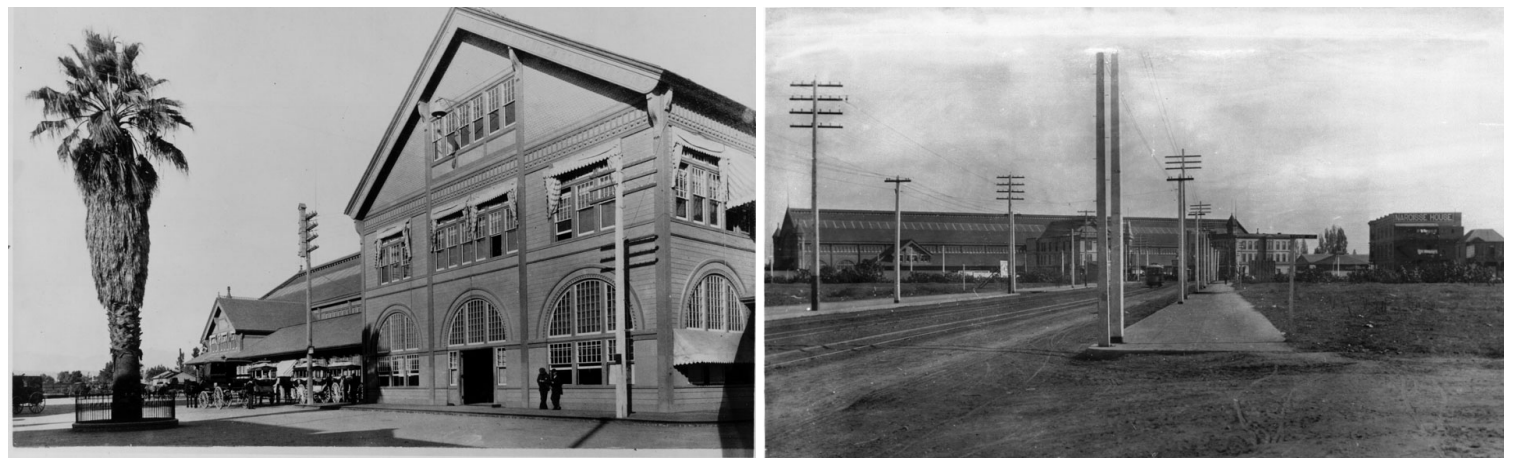

Figure 4.9 (Left). The Southern Pacific Arcade Depot, 1890 (The Examiner)

Figure 4.10 (Right). Looking east along 5th Street towards the Arcade Depot, ca. 1890 (CHS) 
system." (Ch. 16) The specific form that development on the Wolfskill tract took was that of the T-town. T-towns developed on one side of the railroad tracks, as opposed to earlier railroad towns that developed on both side of the tracks. The primary street, in this case 5th Street, ran perpendicular from the station and provided the organizational axis for development.

The Southern Pacific's main competitor in the race to complete a direct transcontinental link to Los Angeles was the Atchison, Topeka, and Santa Fe railroad ("Santa Fe"). By 1887, the Santa Fe had completed its own direct connection to Downtown Los Angeles and in 1893 it opened its La Grande Station by the Los Angeles River on Santa Fe Avenue between 1 st and 2nd Streets. (Figure 4.11) Unlike the Arcade Depot, few hotels developed around La Grande Station and the area took on

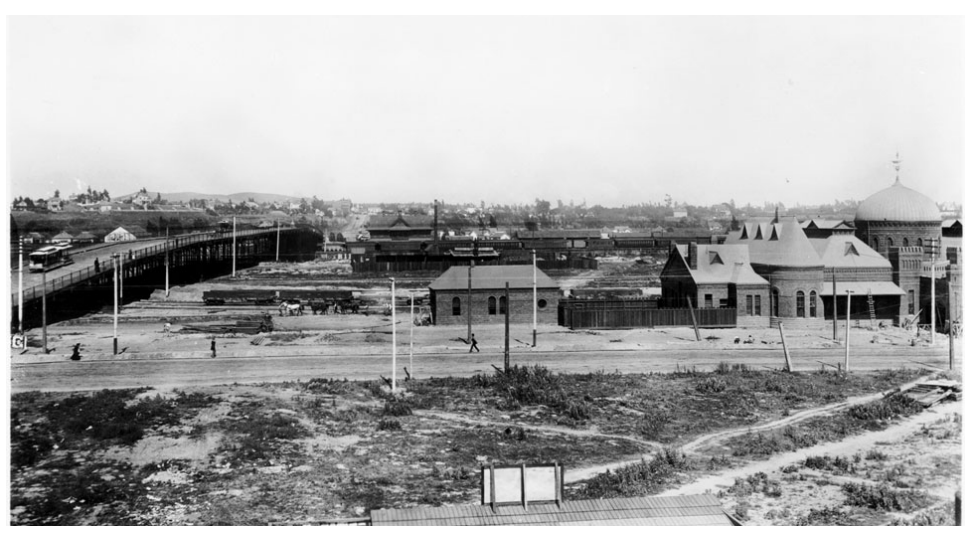
Figure 4.11. Santa Fe La Grande Depot with the First Street Viaduct visible to the left. (CHS)

a more industrial character

due to its distance from the business district and its proximity to the river. However, the station was connected to the business district by 1 st Street, which by this time was a well established corridor linking the business district, what would soon become Little Tokyo, and Boyle Heights. (DeVerteuil, et al., 2004, p. 14)

Located across the river from La Grande Station was the Union Pacific First Street Depot, built in 1891. The station served as the main passenger terminal for the Los Angeles Terminal Railway connecting Los Angeles to Terminal Island in San Pedro. By 1905, this railroad had been extended northward to Salt Lake City via Las Vegas. Like the La Grande Station, the First Street Depot spurred industrialization along the Los Angeles River, but was linked to districts on both sides of the river via 1st Street. (DeVerteuil, et al., 2004, p. 15) 


\section{$\underline{\text { Street Railways }}$}

The City's expanding streetcar network played a significant role in the city's speculationdriven growth by opening up ever-larger expanses of land for development and urbanization. As Longstreth (1997) notes, construction of street railways in Downtown Los Angeles during this period followed the path of least resistance south and westward along the flatlands along the base of Bunker Hill. (p. 24) These railway lines, initially propelled by horses, stimulated development of land adjacent to their routes and facilitated the expansion of the business core south of 1 st Street. However, early cable cars were also built to traverse Bunker Hill and open the hilly land to the west of Downtown to development.

Two cable car lines in particular, both opened in in the mid1880s, reinforced Downtown's shift southward and westward. The West Second Street Cable Railway began operating in 1885 and ran from 2nd and Spring Streets, over Bunker Hill, to the open land to the west. (Figures

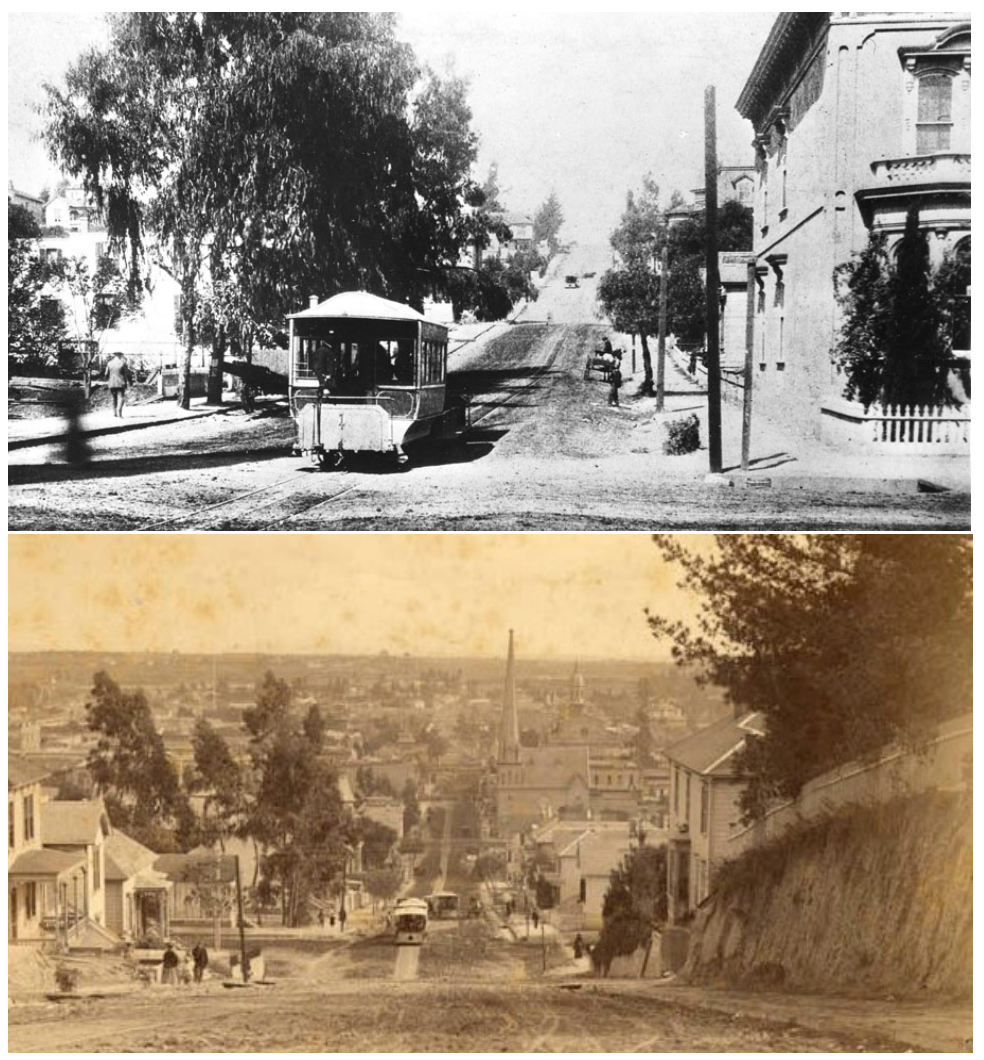

Figure 4.12 (Top). Second Street Cable Railway looking west 2nd and Broadway (CHS)

Figure 4.13 (Bottom). Looking east from 2nd and Grand, 1886 $4.12 \& 4.13)$ A cable car line from

First and Spring Streets to Boyle Heights east of the LA River opened in 1889. Beginning in 1886, several long distance commuter rail lines to surrounding cities such as Pasadena, Burbank, Hollywood, and Santa Monica were also constructed. Many of these lines were eventually consolidated, reconstructed, and incorporated into Pacific Electric interurban system (aka Red Cars) by Henry Huntington in 1901. (Metro Transportation Library, 2012; Electric Railway Historical Association of Southern California, Los Angeles Pacific Corporate Histories, n.d.) 
Urban Form and Functions

During the land boom of the 1880s, hotels and civic buildings, followed by offices and retail commercial enterprises, began to be constructed south of 1st Street. Longstreth (1997) describes the size and organization of Downtown by the end of the 19th century:

In 1900, the core was modest in size and scale, covering less than twenty square blocks. Main Street was the city's thoroughfare. Retail activity concentrated along Spring Street, although some merchants remained in their older Main Street locations and a number of the most prominent stores had recently relocated to Broadway. (p. 23)

As the city's urban functions shifted southward, they also began to separate into specialized groupings along the corridors of Main Street, Spring Street, and Broadway. During this period, Los Angeles' industrial base remained relatively small compared to other US cities and was concentrated in the area east of Main Street and along the river where the train tracks were routed. The following section traces how new development associated with four distinct urban functions - hotels, civic/institutional, office/financial, and commercial - either led or followed this shift in Downtown's center.

$\underline{\text { Hotels }}$

The establishment of rail links to San Francisco and the east spurred the construction of a second generation of hotels. Like streetcars, hotels were often closely linked to civic boosterism and its associated land speculation. According to Groth (1994), "An imposing hotel became an essential ingredient for any aspiring city in the battle to attract new capital investors and professionals. Emulating the chartered companies of wealthy merchants in established cities, boosters on the urban frontier built ever-larger and more imposing hotels each generation." (p. 39)

Built in 1882 on the southwest corner of 1st and Spring Streets (where the Times building now stands), the Hotel Nadeau replaced the Pico House as the city's finest hotel and marked downtown's initial incursion into the area south of 1st Street. (McCann, et al., 2008, p. 19) (Figure 4.14) The Nadeau was joined in 1883 by the Natick House one block to the east on Main 

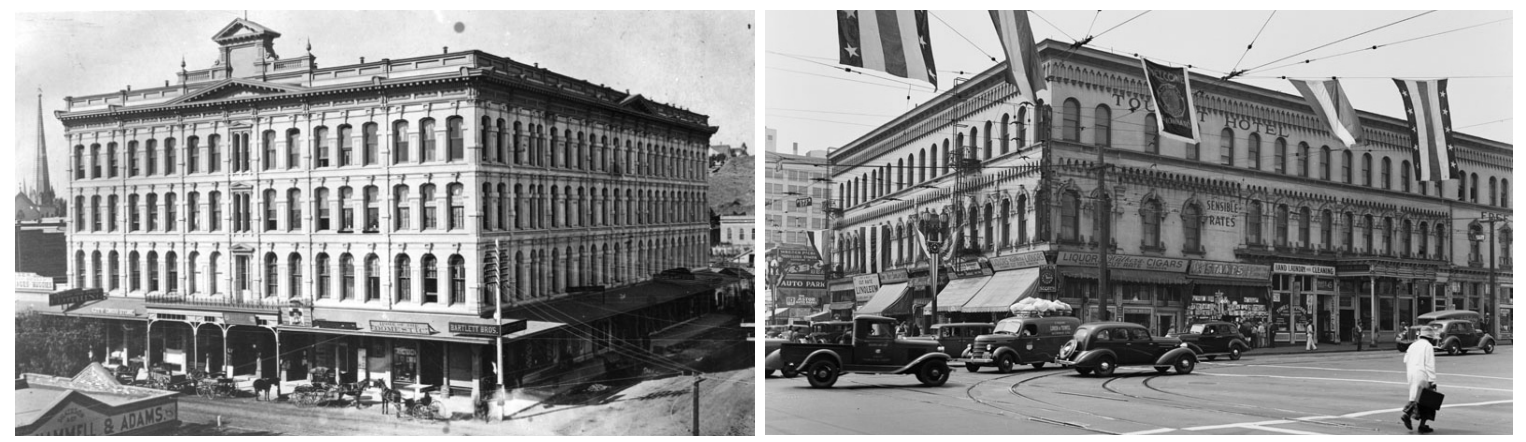

Figure 4.14 (Left). Hotel Nadeau, 1886 (Los Angeles Public Library)

Figure 4.15 (Right). Natick House Hotel, 1939 (Los Angeles Public Library)

Street. (Figure 4.15) The Hollenbeck Hotel (1884) at the southwest corner of 2nd Street and the Westminster Hotel (1887) at the northeast corner of 4th and Main pioneered locations at the southern edge of downtown. (pp. 23, 28)

\section{Civic/Institutional}

Prior to the 1880s, Los Angeles' civic, governmental, and institutional functions, like so many of its other urban functions, were centered on the Temple Block area. However, after the arrival of the railroads, many of these functions were relocated along the Broadway corridor, contributing to downtown's southward expansion while also shifting it westward to Broadway.

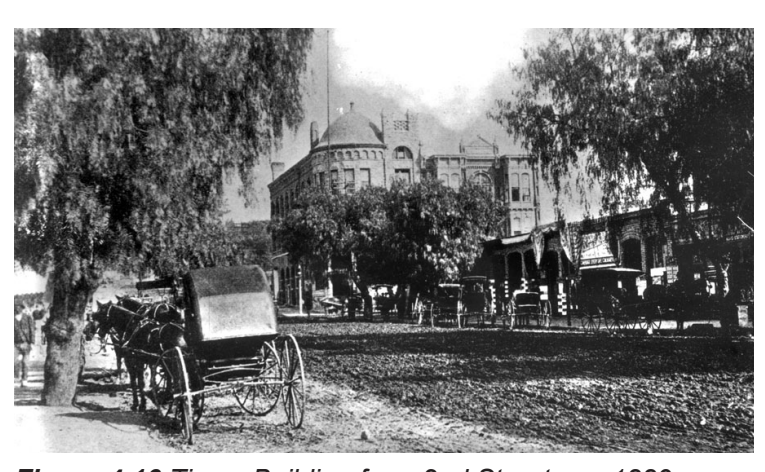

Figure 4.16 Times Building from 2nd Street, ca. 1889 (CHS)
In 1886, Harrison Gray Otis pioneered the development of the Broadway corridor after moving the offices of the Los Angeles Times from the Downey Block to a new building on the northeast corner of 1st and Broadway. (Figure 4.16) Two years later, the city finished construction of a new City Hall on the east side of Broadway between 2nd and 3rd Streets (where the Los Angeles Times Parking Garage

now stands). (Figure 4.17) Then, in 1891, Los Angeles County constructed a new courthouse at the corner of Broadway and Temple Street, atop of what was then known as Poundcake Hill. (Figure 4.18) The third and last major pre-Civic Center government building to be constructed along Broadway was the County Hall of Records, built in 1912 immediately south of the County Courthouse. (Stargel \& Stargel, 2009, pp. 39-40) 

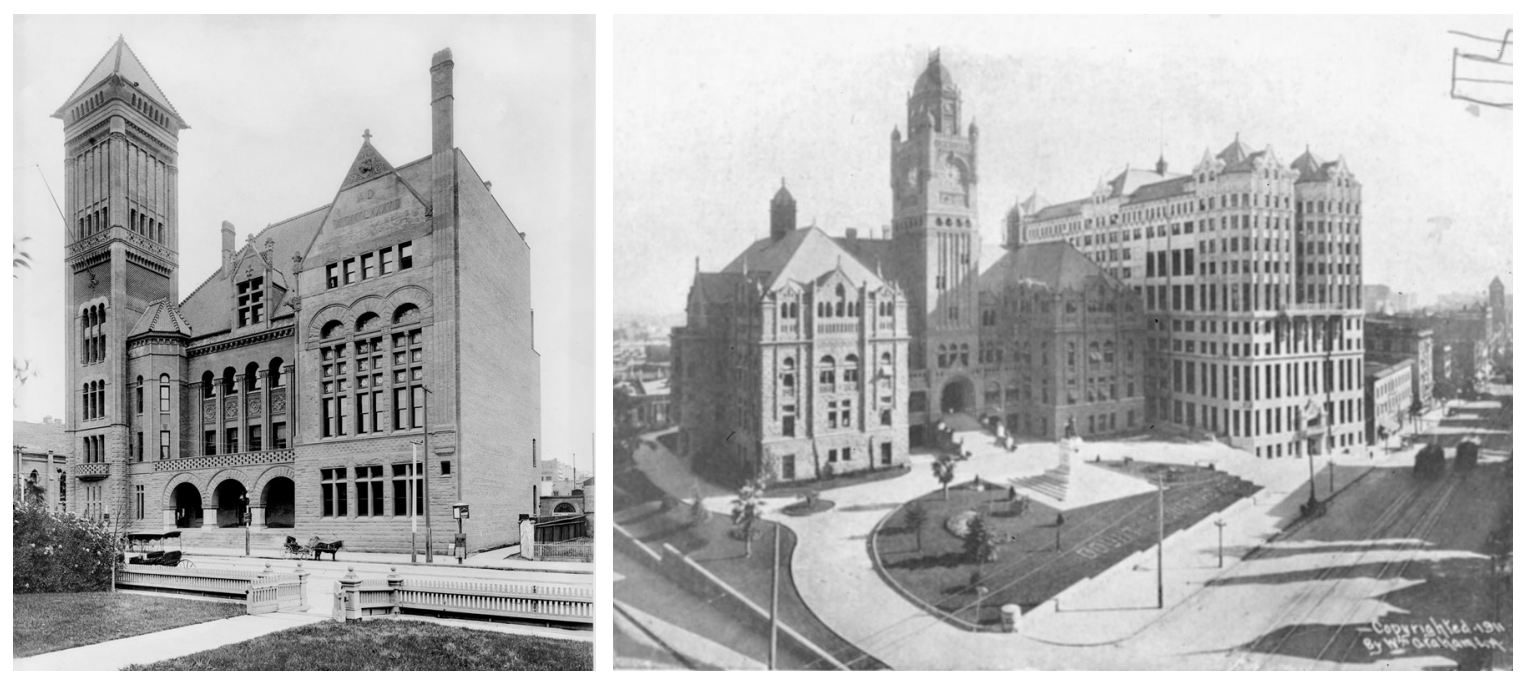

Figure 4.17 (Left). City Hall, ca. 1890 (CHS)

Figure 4.18 (Right). Los Angeles County Courthouse and Hall of Records (The Examiner)

Not all governmental buildings were built along Broadway during this period however. The first federal building constructed in the city was the US post office, built in 1893 at Main and Winston Streets (between 4th and 5th Streets). In 1908, a new post office and federal building was constructed at Spring and Temple Streets on the former site of the Downey Block (Stargel \& Stargel, 2009, p. 44)

\section{Office/Financial}

The migration of office and financial functions south of 1st Street lagged behind the migration of hotel and civic/institutional functions. When they did begin to be relocated out of the Temple Block area, they generally followed Spring Street

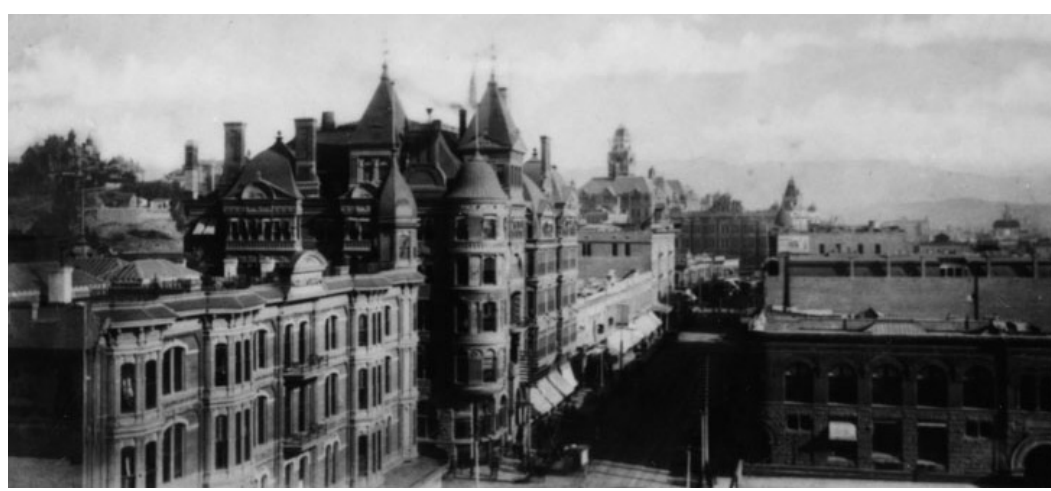

Figure 4.19. Looking north on Spring Street showing the Hollenbeck Hotel and the Bryson Block with the County Courthouse and the Phillips Block visible in the background (Los Angeles Public Library)

southward. However, new private office building continued to be built north of 1st Street into the early 20 th century. 
The Los Angeles National

Bank (northeast corner of 1 st \& Spring) and the Bryson Block (northwest corner of 2 nd \& Spring) were the first major office buildings built south of the Temple Block. (Figure 4.19) Both were constructed in 1888 , the same year that

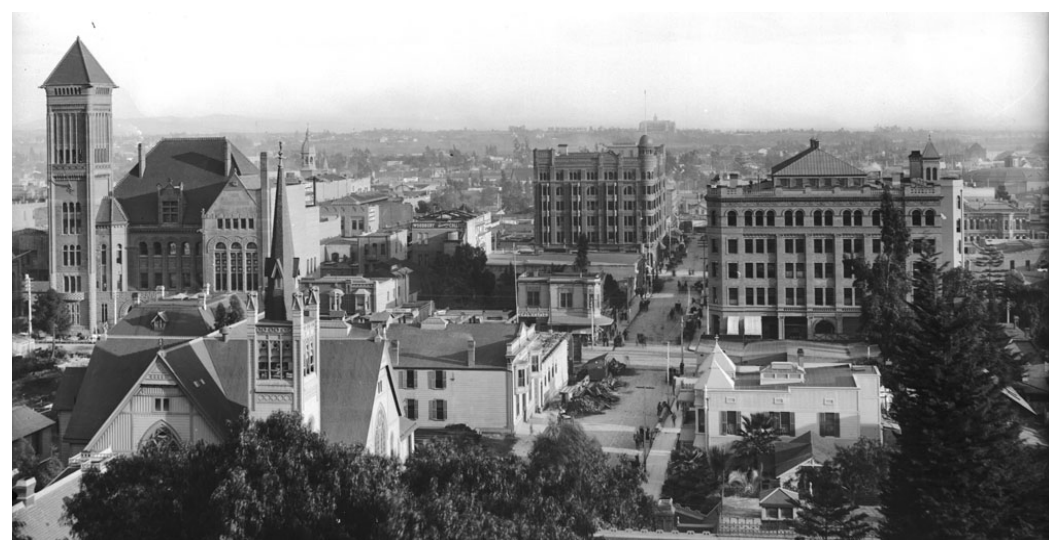

Figure 4.20. Looking east along 3rd Street from Bunker Hill, showing City Hall (left), the Stimson Building (center rear), and the Bradbury Building (right) (CHS)

the Southern Pacific's Arcade Depot opened. The locations of these two buildings are notable because they were also the termini of the two recently completed cable railways. (Shannon, 2009) The Los Angeles Trust Company building and the Wilcox Building (1896) later joined the Bryson Block on the corner of 2nd Street, while the Lankershim, Stimson (1893), and Douglas (1898) buildings sprang up at the corner of 3rd Street. The Bradbury Building (1893) was also built at 3rd Street and Broadway during this period. (Figure 4.20)

\section{$\underline{\text { Commercial }}$}

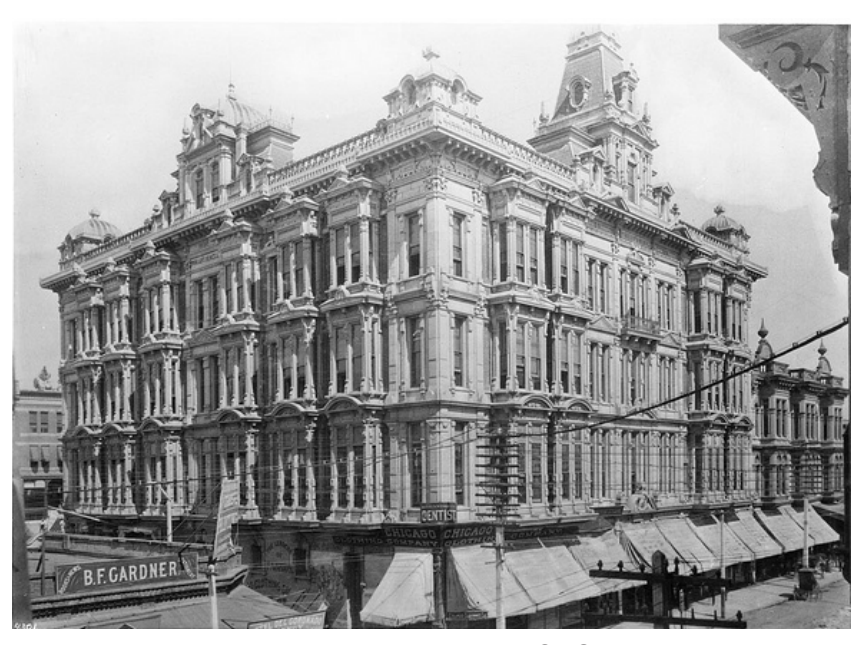

Figure 4.21. The Phillips Block, ca. 1890 (CHS)
Like the office/financial functions, the city's commercial enterprises lagged behind other functions in the southward shift of Downtown. However, the migration of Los Angeles' commercial enterprises laid the groundwork for the growth of the city's large department stores of the early 20th century. Throughout the 1880 s, retail remained concentrated along Main and Spring Streets north of First Street. The Phillips Block, built in 1887 at Spring and Franklin Streets (just north of First Street), represented the first significant increase in the scale of commercial enterprises in the city. (Figure 4.21) The 
dry goods company A. Hamburger \& Sons expanded its operation by moving into the building in 1890. The company remained at this location until 1908 when it built a massive new 500,000 sf building at Broadway and 8th Street that still stands today. (Longstreth, 1997, pp. 24-6)

Hamburger's primary rival was the

Broadway Department Store, founded in 1896 on the SW corner of 4th \& Broadway, which at the time was considered the edge of downtown. (Figure 4.22) In in 1912, the company built a new 460,000 sf store on the same site. That building still stands today and is currently being used as a State office building. (Longstreth, 1997, pp. 24, 29)

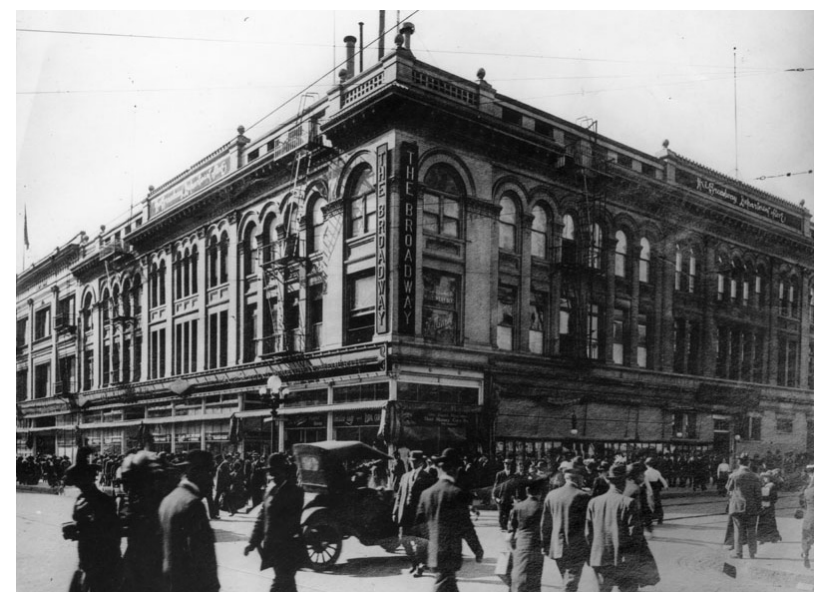

Figure 4.22. The Broadway Department Store (Los Angeles Public Library)

The J.W. Robinson Co. began life as the Boston Dry Goods Store and was initially located at the corner of N. Spring Street and Temple Street. The company moved to larger quarters at 69-73

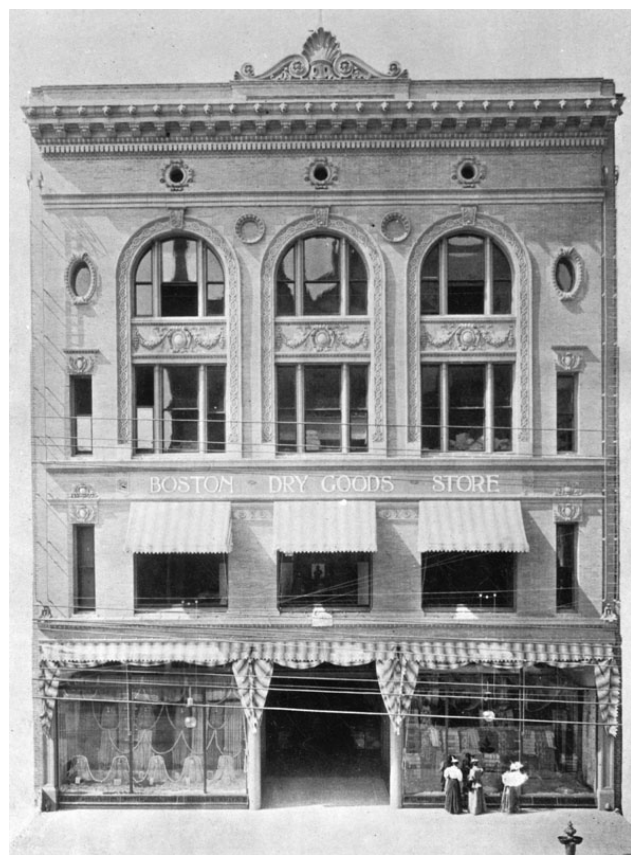

Figure 4.23. The Boston Dry Goods Store (Los Angeles Public Library)
N. Spring Street in 1887 (near the newly completed Phillips Block). (BAK, 2010) Then in 1895 (a year before the Broadway was founded), Robinsons became one of the first major stores to relocate to Broadway when it moved into a new building at $239 \mathrm{~S}$. Broadway, across from City Hall. (Figure 4.23) In 1915, Robinson completed and moved into a new 400,000 sf store on Seventh Street between Grand and Hope Streets. (Longstreth, 1997, p. 11) Both of these buildings still stand today, though the building on Broadway has had its upper floors removed and is currently occupied by the Guadalupe Wedding Chapel. 


\section{Segregated Housing Districts}

As the city expanded and downtown shifted south- and westward, the residential districts around the central business district shifted and grew as well. As wealthy and upwardly mobile residents settled on outlying tracts in the southern and western flats, ethnic and racial minorities and poorer white residents settled in the older districts north of First Street and the areas east of Main Street near the city's industrial district. (Fogelson, 1967, p. 138)

\section{El Pueblo/Sonora Town}

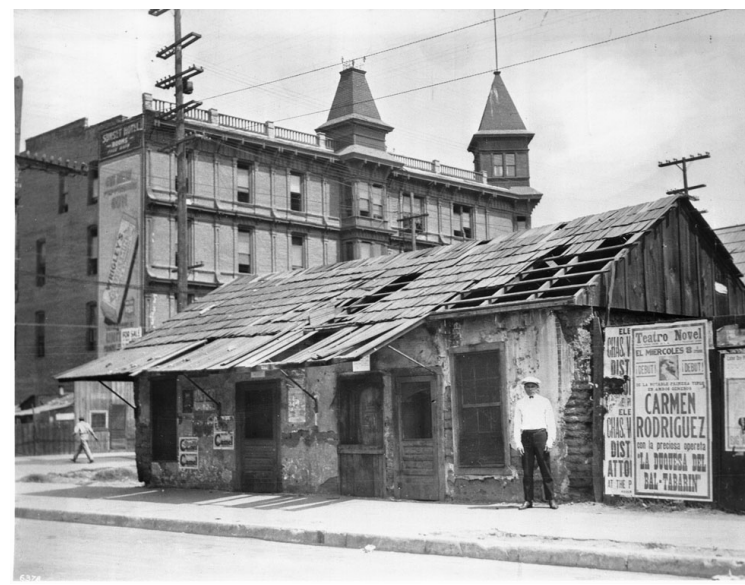

Figure 4.24. An old adobe in Sonora Town, ca.1920 (CHS)
From the 1850s onward, the area north of the Plaza came to be known among AngloAmerican population as Sonora Town due to the fact that many of the area's residents had migrated from Mexican state of Sonora. The segregation of the city's Mexican and MexicanAmerican populations reflected their social and economic marginalization within the city. The formation of this barrio also reflects the largescale disenfranchisement of Mexican-American

landowners following the transition to American governance and the collapse of the rancho economy. (Griswold del Castillo, 1979, p.40-1)

As a racially segregated barrio made up of decaying adobes, El Pueblo and Sonora Town unofficially served functions deemed unsuitable for more upscale parts of town. (Figure 4.24) As Griswold del Castillo explains (1979), "In many respects, old Los Angeles resembled a presentday border town - vices forbidden in the Anglo community could be satisfied in the barrio." (p. 70) The area's location between the Southern Pacific's River Station and the city's central business district also contributed to much of the area's crime and racially driven violence, since many Anglo-American gold miners entering the city stopped off there. (p. 40-1) 


\section{Chinatown}

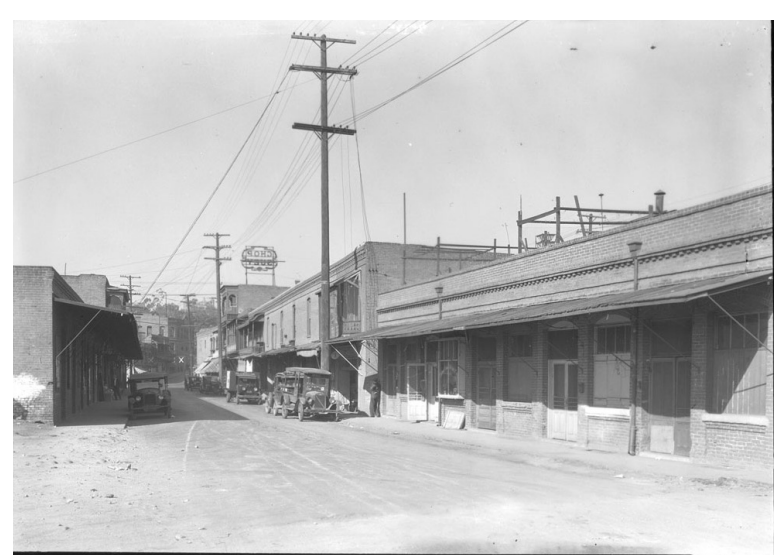

Figure 4.25. Looking west along Marchessault Street towards town were allowed to flourish in Chinatown. Alameda Street, ca. 1900 (CHS)

(Griswold del Castillo, 1979, p. 141-9) And like

Sonora Town, Chinatown was the site of a significant amount of racially driven violence, including the Chinese massacre of 1871. (McCann, et al., 2008, p. 12) Eventually, the residents of this area were relocated to the present-day site of Chinatown to make way for the construction of Union Station in 1939.

\section{Main Street}

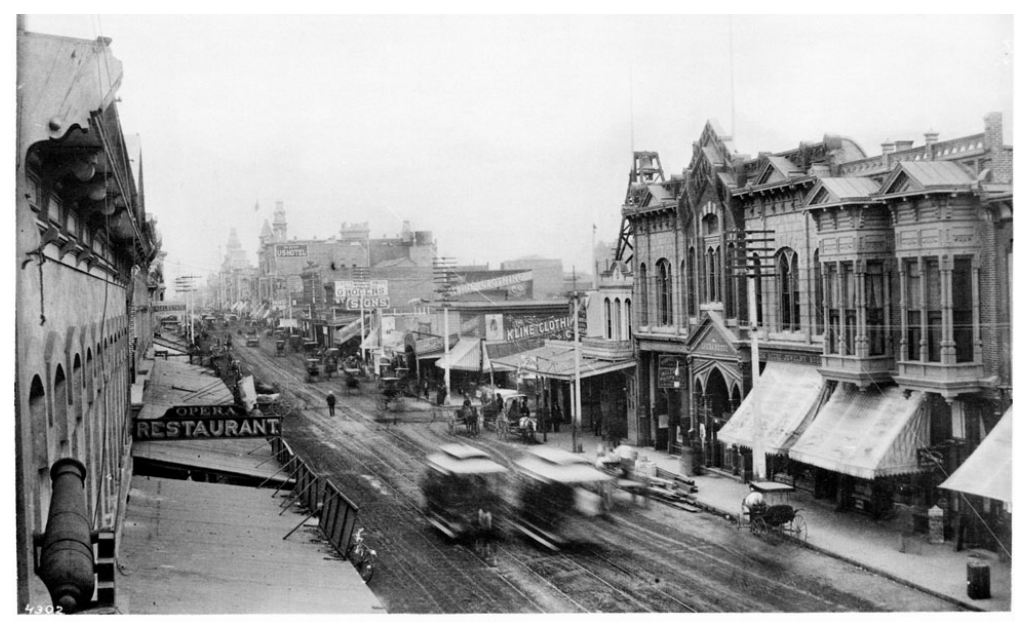

Figure 4.26. Looking north along Main Street from mid-block between 1st and 2nd Streets, ca. 1889 (CHS)
As the city's wealth and new development shifted southward and westward, the hotels along Main Street lost their primacy and became increasingly associated with the racially heterogeneous, poorer, and run-down areas to the north and east. (Figure 4.26) Previously upscale hotels were converted into low-budget lodging houses catering to a poor, ethnically diverse, predominately male population. (McCann, 
et al., 2008, p. 12) This gradual filtering of hotel clientele reflected both the city's expansion and the decline of older hotels and the districts where they were situated. Groth (1994) explains this filtering process in greater detail:

For all types of hotels, shifts in social cachet, demographic changes in surrounding neighborhoods, or losses in nearby employment triggered the process of filtering: first, former permanent guests gradually filtered out to newer, more comfortable, or betterlocated quarters; second, to keep occupancy levels high, managers at the older hotels lowered their prices, allowing less affluent tenants to filter in; finally, the remaining earlier tenants left, feeling that their social standing, comfort, or safety was in jeopardy. In any American city, it was not unusual in the 1920s to see handsomely designed and fashionable family hotels of the 1880s that had devolved to inexpensive rooming houses for unskilled or unemployed workers. (p. 184)

\section{Little Tokyo}

The area known today as Little Tokyo started as an ethnically mixed area populated by Chinese, Black and Jewish ethnic groups. The first Japanese business in the neighborhood was a restaurant opened in 1885, followed by two more by 1890 . By the late 1890 s there were 16 Japanese-owned restaurants in the area. However, it was not until 1903 that the area began to be known as Little Tokyo. Following the 1906 San Francisco earthquake, many "Nikkei" (persons of Japanese heritage) migrated to Los Angeles and settled in Little Tokyo. The district prospered until the US's entry into World War II when Little Tokyo was emptied of most of its population after the US instituted the internment of all people of Japanese ancestry on the West Coast. (U.S. National Park Service, n.d.)

\section{Skid Row}

The area known today as Skid Row developed after the Southern Pacific built its Arcade Depot on Central Avenue between 4th and 5th Streets. Soon thereafter, the orchards of the Wolfskill tract were rapidly replaced with newly constructed single-room occupancy hotels serving a transient population of mostly single, male, short-term and seasonal workers as well as recent arrivals to the city. (Figure 4.27) As Spivak (1998) describes: 
Because the area had predominantly a single adult male population, it attracted services that catered to that population, including small shops; bars, saloons and restaurants; brothels, the forerunners of today's "dance clubs"; and other social, recreational and meeting places. Some of the organizations that evolved into

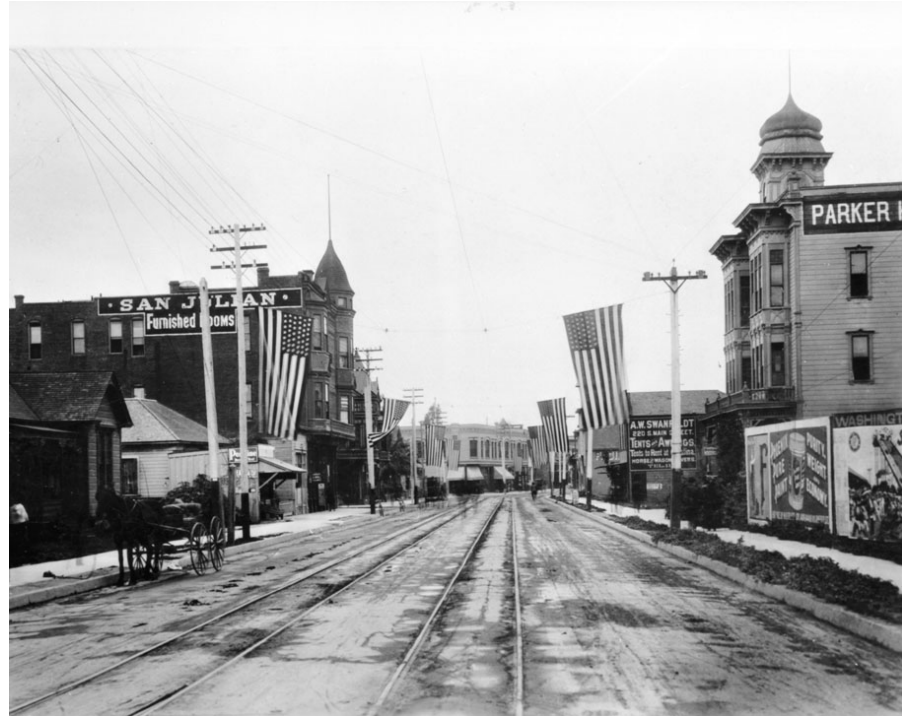

Figure 4.27. Fifth Street looking west from Towne Avenue, May 1891 (CHS)

the social service organizations of today started as organizations to serve a temporary population with cultural, recreational or other diversions and with services which people away from home needed.

\section{Bunker Hill}

After being purchased and subdivided by French-Canadian merchant and future city mayor Prudent Beaudry in 1867, Bunker Hill became one of Los Angeles' most prestigious residential districts by the end of the 19th century. (Dawson, 2008, p. 9) Many of the city wealthiest early residents built large ornate mansions atop the hill. (Figure 4.28) The Second Street Cable Railway, financed largely by owners of property west of the downtown and completed in 1885 , significantly contributed to the development of Bunker Hill. (Rice, 2008) Around the turn of the century, many of the former mansions began to be subdivided the background, 1898 (CHS)

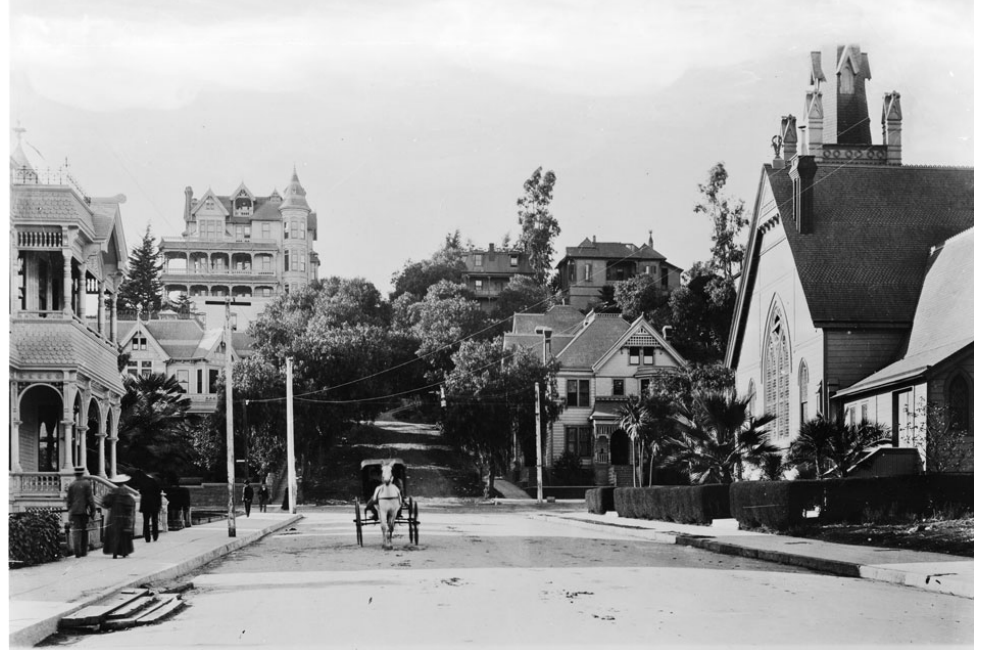

Figure 4.28. Looking west at the intersection of 3rd and Hill with Bunker Hill in 
into rooming houses and joined by new hotels and more modest homes. At the end of 1901, the Angel's Flight funicular began operations shuttling residents and commuters up and down the steep hillside above 3rd and Hill Streets. (Dawson, 2008, p. 17)

During the early decades of the 20th century, Bunker Hill experienced a similar process of filtering that Main Street experienced a generation earlier. As wealthy residents migrated to more fashionable and distant neighborhoods like West Adams, elderly and low-income residents increasingly occupied the hotels and rooming houses of Bunker Hill. (McCann, et al., 2008, p. 29) By the end of the 1960s, the Los Angeles Community Redevelopment Agency had cleared the entire neighborhood to make way for the office district and skyline that occupies the Hill today. 


\section{Early 20th Century developments}

Los Angeles' explosive population growth and spatial expansion continued and intensified in the early 20th century. As the city expanded farther outward, so did its commercial core. Whereas hotel and civic functions led Downtown's shift in the late 19th century, the city's expanding department stores led the way in the new century by pioneering new land for development at the edge of Downtown. By the eve of redevelopment, new commercial centers began to appear far beyond the urban core, challenging Downtown's commercial supremacy. At the same time, automobile ownership skyrocketed in Los Angeles County, breaking the monopoly that electric railway companies had on transportation in the metropolis. These factors placed increasing strain on Downtown's commercial viability and land values, particularly its older sections, and provided the impetus for the large-scale interventions of redevelopment and urban renewal.

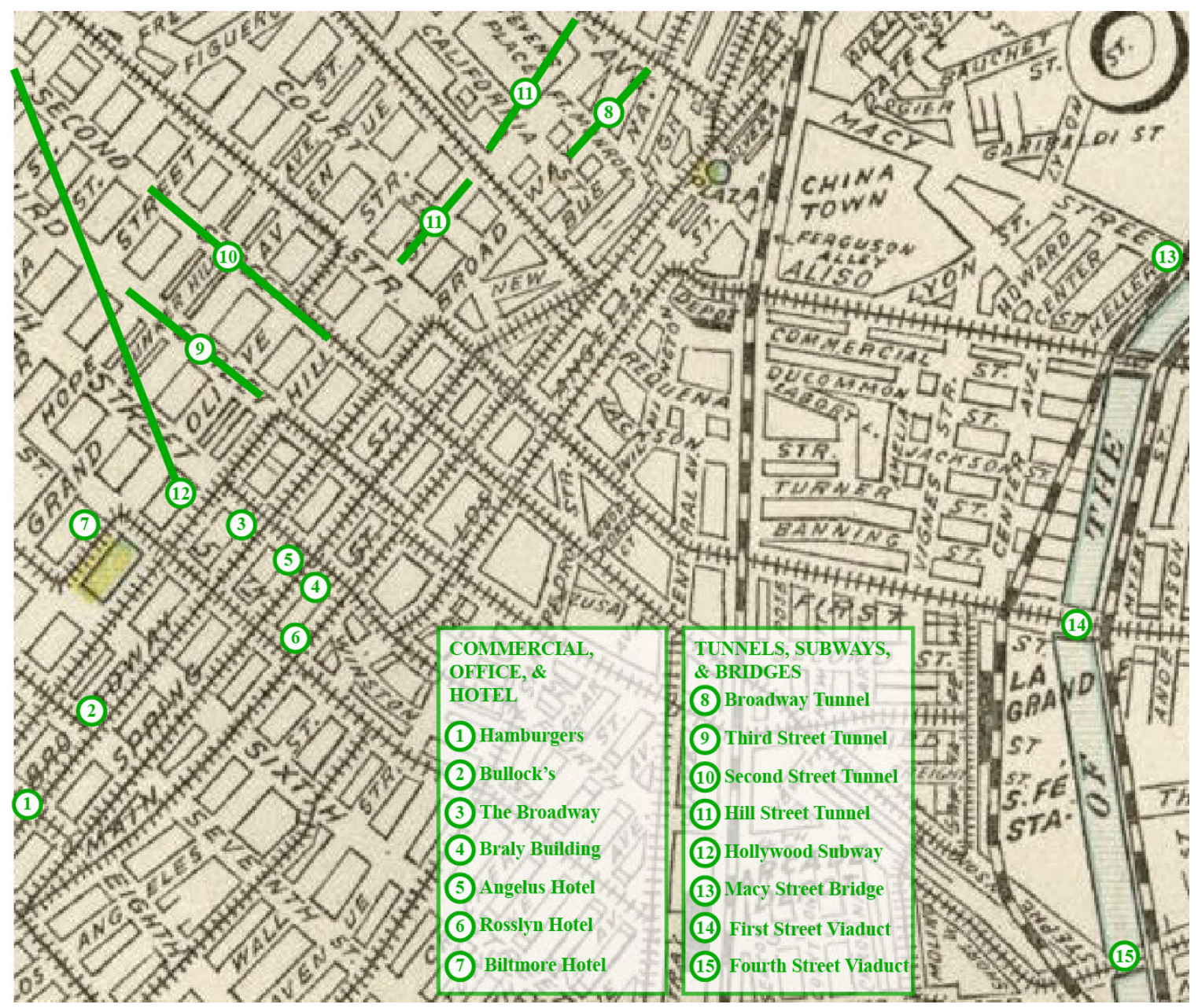

Figure 4.29. Reference map of early 20th century development (Base Map: CHS) 


\section{$\underline{\text { Commercial }}$}

When Hamburger's relocated to its massive new store at 8th and Broadway in 1908, it pioneered a location then considered on the outskirts of the central business district. Soon after, however, it was joined by Bullock's at 7th and Broadway, a new Broadway department store at 4th and Broadway, and J.W. Robinson's on 7th between Grand and Hope Streets. The relocation of the city's largest department stores contributed to a shift in Downtown's key functions away from the area north of 3rd Street to the area around the intersection of 7th and Broadway. The J.W. Robinson's store also helped redirect Downtown's expansion westward along 6th and 7th Streets. (Longstreth, 1997, p. 23) By the 1930s, however, large new commercial districts serving new communities beyond the urban core began to challenge Downtown as whole for commercial supremacy within the region. (p. 58)

\section{Office}

During the early 20th century, the city's financial institutions steadily relocated to new, larger office buildings along Spring Street south of 4th Street, soon earning Spring Street the moniker of "Wall Street of the West." (Stargel \& Stargel, 2009, pp. 7-8) (Figures 4.30 \& 4.31) This southward expansion of the city's financial institutions was kicked off in 1904 with the completion of the Braly Building at the SE corner of 4th and Spring Streets. At 175 feet tall, it remained the tallest building
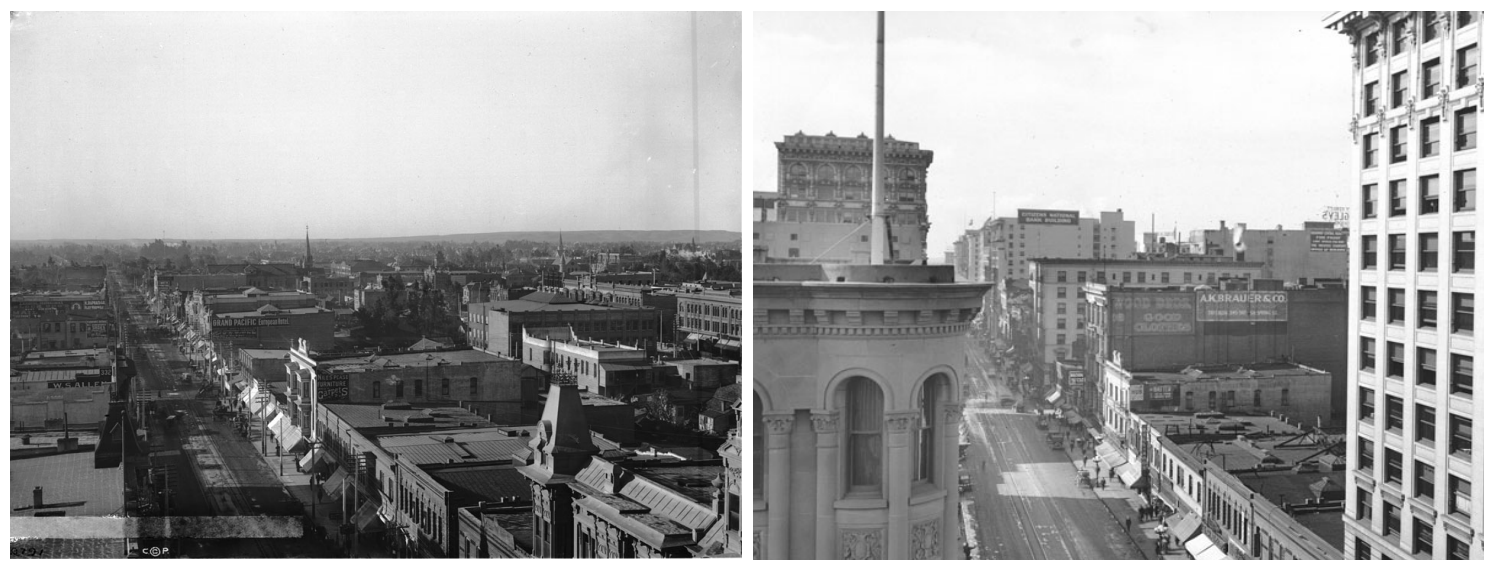

Figure 4.30. (Left) Spring Street, looking south from 3rd Street, Los Angeles, November 1898 (CHS) Figure 4.31. (Right) Spring Street, looking south from 3rd Street, Los Angeles, November 1917 (CHS) 
in the city until the current City Hall was completed in 1928. Shortly after completion of the Braly building, the city imposed a 150-foot height limit on all downtown buildings. (Stargel \& Stargel, 2009, p. 46)

\section{Downtown and Suburban Residential Development}

During the early 20th century, most new downtown hotel construction occurred south of 4th Street and on Bunker Hill. Notable hotels built during this period include the Angeles Hotel (1901) at 4th and Spring Streets, the Rosslyn Hotel (1914) and its annex (1923) at 5th and Main Streets, and the Biltmore Hotel (1923) on Pershing Square. (McCann, et al., 2008, pp. 54, 60, 66) Around this time, many wealthy Angelenos began moving out of the center city, first to upscale districts like West Adams and Westlake, then later to fashionable new communities like Hollywood, Miracle Mile, Beverly Hills, and Westwood Village. These new communities developed their own commercial centers that began to challenge Downtown's supremacy as a regional commercial hub. (Longstreth, 1997, p. 58) The hotels and mansions that were left behind steadily filtered down to serve low-income and racially/ethnically diverse new arrivals to the city.

\section{Streets and Infrastructure}

Los Angeles' outward expansion during the 20th century brought intense pressure to bear upon the infrastructure of the city's central core. The road, rail, and bridge networks strained under the weight of so much growth, particularly as the personal automobile became the dominant mode of transportation in the metropolis. City leaders responded with a series of infrastructure projects intended to alleviate congestion and restore access to the urban core.

\section{Tunnels}

In 1901, the Broadway tunnel was completed under Fort Moore Hill, connecting Temple Street and Sunset Boulevard. (Figure 4.32) The 760 foot long and 40 foot wide tunnel was built to alleviate congestion on Main Street and improve access to the central business district. The tunnel allowed

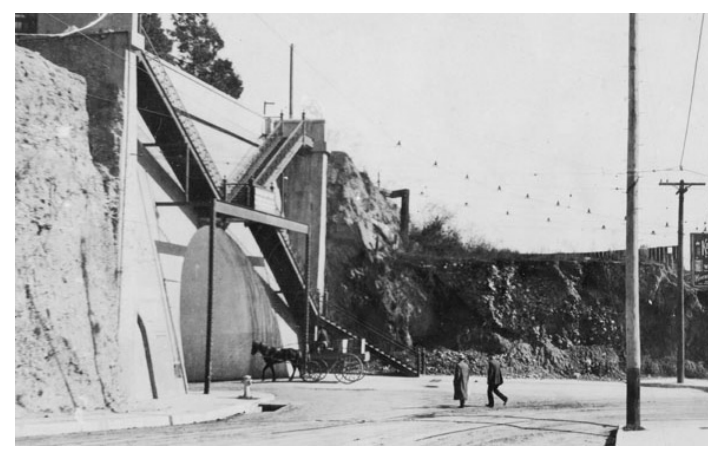

Figure 4.32. Entrance to the Broadway Tunnel (Los Angeles Public Library) 
horse carriages and later automobiles to bypass Main Street and reach the Broadway corridor directly from the north. (Masters, 2012; Richardson, December 27, 2008)

In the same year, the Third Street tunnel was completed under Bunker Hill between Hill and Hope Streets. (Figure 4.33) The tunnel provided access between the central business district and the Crown Hill neighborhood to the west. Twenty-four years later, the Second Street Tunnel, was built in a belated attempt to ease congestion on the earlier tunnel under Bunker Hill. In subsequent decades, even larger scale interventions would be employed to address congestion. (Richardson, September 5,

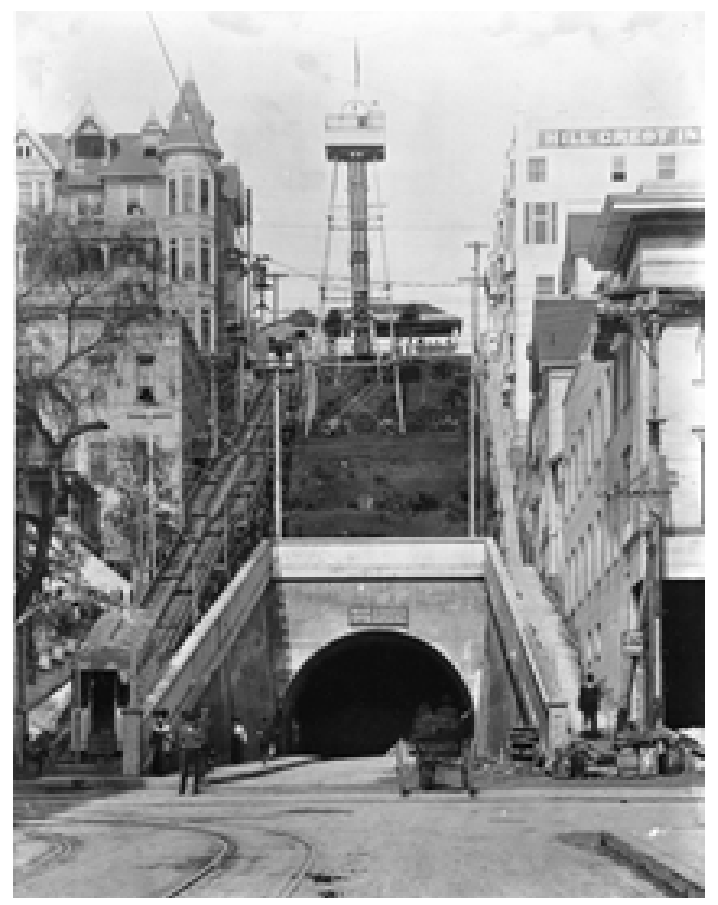

Figure 4.33. Entrance to Third Street Tunnel, 1903 (CHS) 2008)

\section{Electric Railways}

Henry Huntington purchased the Los Angeles Railway (aka the "Yellow Cars") in 1898, ushering in an era of rapid expansion for the local railway system that corresponded with his entry into the local real estate market. (Figures $4.34 \& 4.35$ ) In 1901, he also established the Pacific Electric Railway (aka the "Red Cars") through the purchase and consolidation of several other smaller railroads. The interurban system was greatly expanded after the "Great Merger" of eight separate transit companies in 1911, when the Southern Pacific bought out Huntington's shares in the company. (Metro Transportation Library, 2012)

In 1909, a pair of streetcar tunnels was built, extending Hill Street to Sunset Boulevard. (Figures 4.36 \& 4.37) These tunnels, known as the Los Angeles Pacific Railway Tunnel, allowed Hollywood-bound Red Cars to by-pass the bottleneck on N. Main Street. The first tunnel ran under Court Hill between First and Temple Streets. The second tunnel ran below Fort Moore Hill 


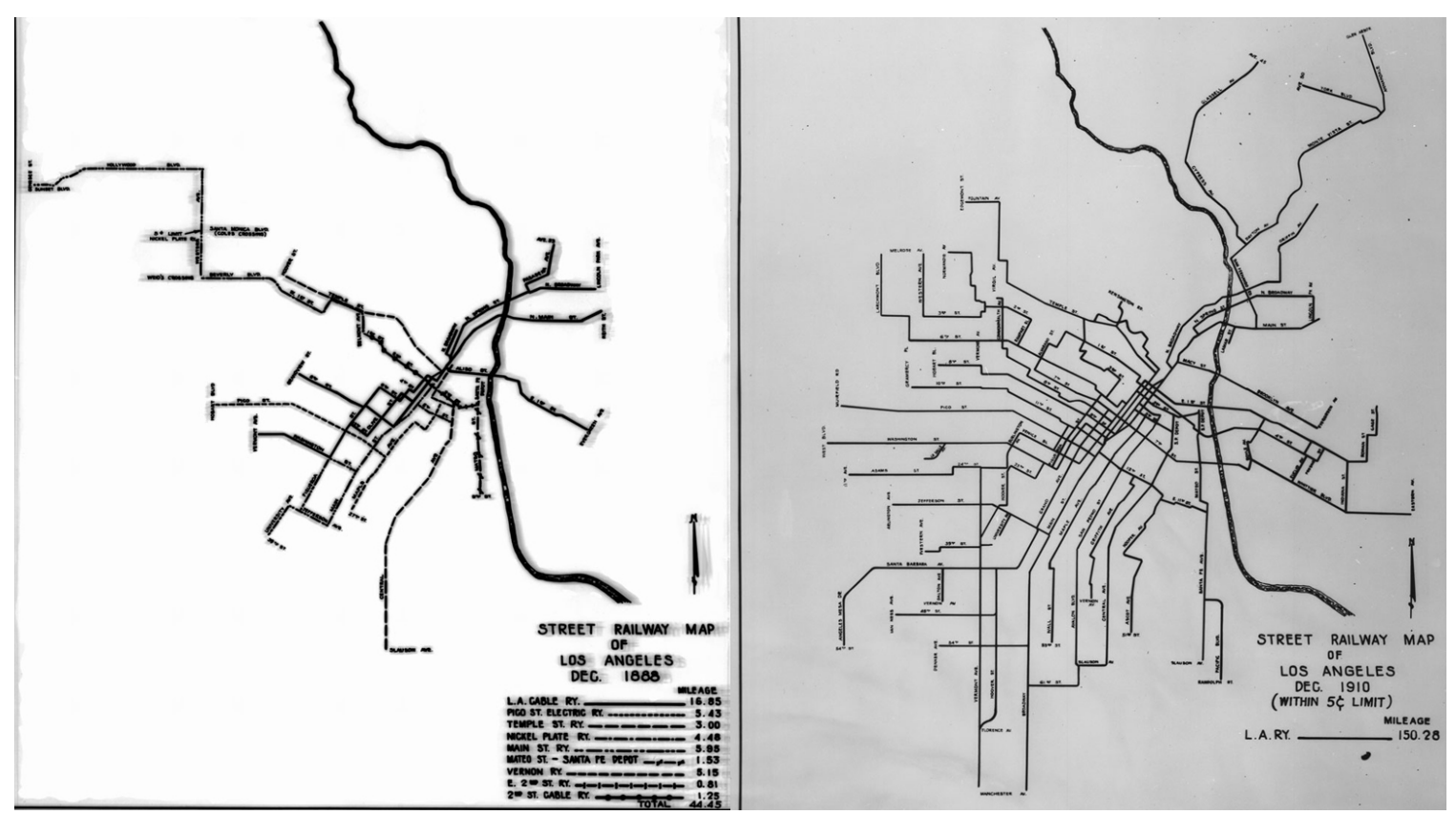

Figure 4.34. (Left) Map of the street railway lines of the Los Angeles street car system, December 1888 (CHS)

Figure 4.35. (Right) Map of the Los Angeles street railway (streetcar) system, ca.1910 (CHS)

from Temple Street and Sunset Boulevard. A vehicular tunnel was subsequently added next to the original tunnel under Court Hill. (Orange Empire Railway Museum, 2012; McCann, Roseman, Taube, et al., 2008, p. 44)

In 1926, Pacific Electric replaced the Hill Street Station with the Subway Terminal Building.

The building stood above the Downtown entrance to the Hollywood subway, which ran from Downtown to its western portal at First Street and Glendale Boulevard. The Hollywood Subway shortened travel time between Downtown and Hollywood by nearly 15 minutes and was intended to be the first segment of a larger subway system connecting the Hill Street terminal to Hollywood

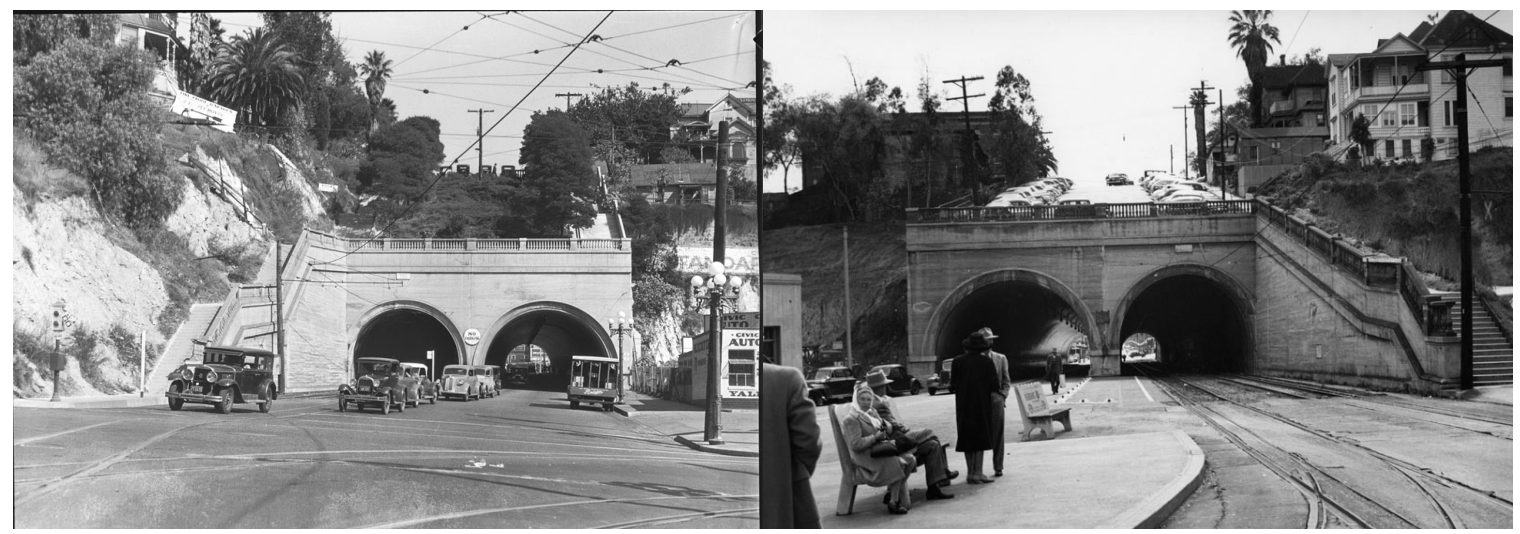

Figure 4.36. (Left) The south portal of the Hill Street Tunnel under Court Hill from Hill and 1st Streets (CHS)

Figure 4.37. (Right) The north portal of the Hill Street Tunnel under Court Hill from Hill and Temple Streets (CHS) 
and to the Vineland Station west of Downtown. However, the Pacific Electric's deteriorating finances, exacerbated by the rise of automobile use, prevented any further construction of a subway system. (Fogelson, 1967, p. 175; Bariscale, 2008)

\section{Bridges}

Between 1909 and 1938 the City of Los Angeles undertook a massive construction program to replace several nineteenth-century metal truss bridges over the Los Angeles River with fourteen new monumental, concrete bridges capable of withstanding the river's seasonal floods. (Los Angeles Conservancy, 2008, p. 6) Built in 1910, the North Main Street Bridge was the first to be completed. (p. 22) The North Broadway-Buena Vista Bridge followed in 1911 and became longest and widest concrete arch bridge in California at the time. (p. 18) Subsequent spans were completed throughout the 1920 s and 30s as part of the city's expanding road network. Included among these spans were the North Spring Street Viaduct (1929), Cesar Chavez/Macy Street Bridge (1926) the First Street Viaduct (1929), and the Fourth Street Viaduct (1931), all of which connected the Civic Center and the 19th century era downtown to points north and east of the river. (pp. 20, 24, 26) 
Chapter 5. Historic Context: Redevelopment 


\section{Introduction}

The redevelopment of the Civic Center area occurred largely within two time periods: a prewar period from 1925 to 1940 and a postwar period from 1949 to1975. Pre-war redevelopment was intended to ease congestion within the city center and create a centralized government administrative complex to anchor Downtown as the region's hub. (Fogelson, 1967, pp. 250-1, 262) The larger-scale redevelopment of the postwar period was intended to advance pre-war goals, but was also intended to remove blight, prop up declining property values, and increase vehicular access to the central business district. (Weiss, 1980, p. 255)

\section{Pre-World War II}

\section{Civic Center Plan}

In 1918, Mayor Frederick T. Woodman appointed a special committee to investigate potential sites for creation of a new civic center. City planners believed that such a civic center would facilitate public affairs, stabilize downtown values, form a regional monument, and prevent dispersal of governmental functions throughout the expanding metropolis. Potential sites included

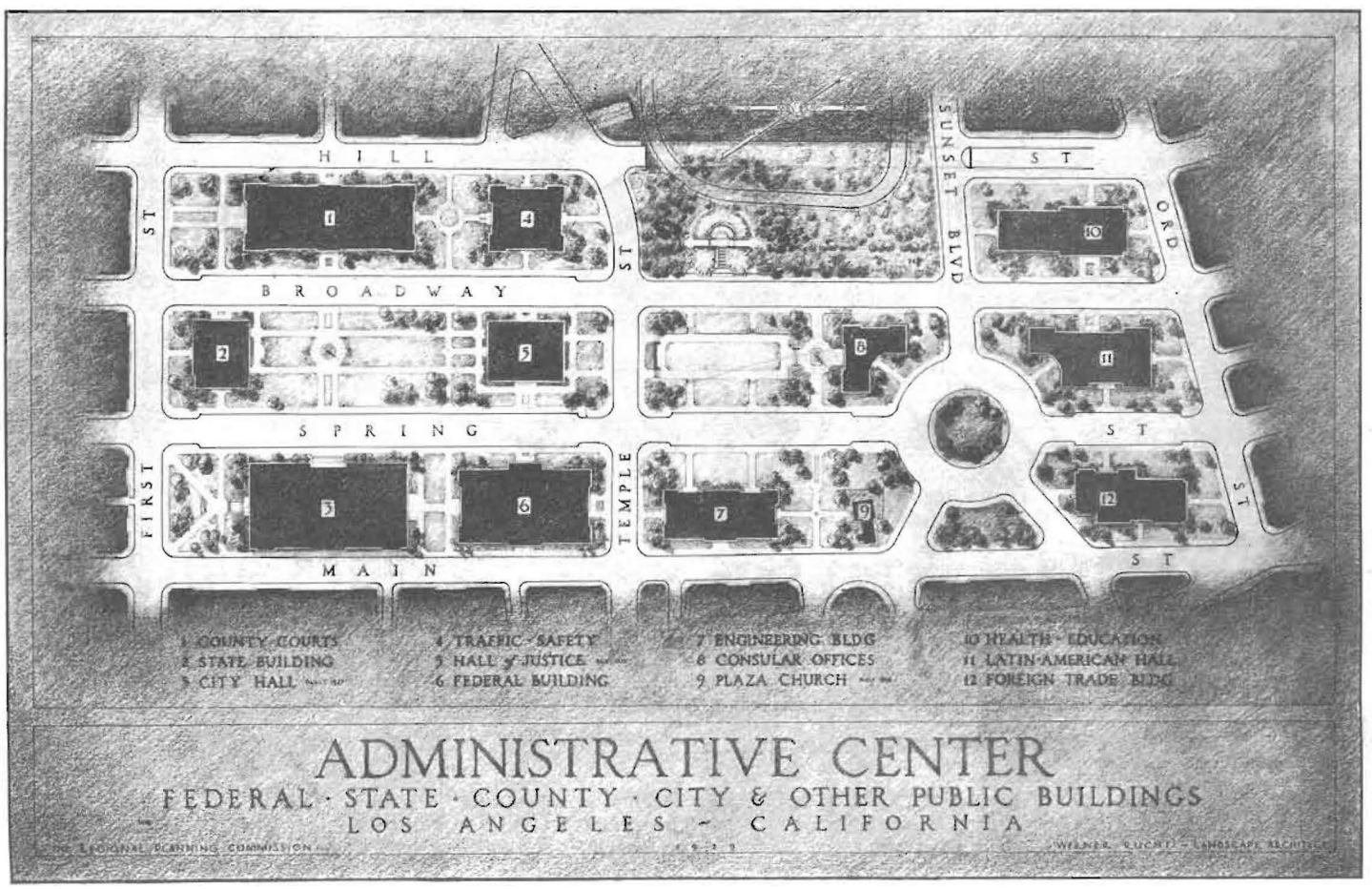

Figure 5.1. Official Civic Center Plan of 1927 (Fogelson, p. 42) 
the southern periphery of the business district, the Pershing Square and Normal Hill area (current site of the Central Library), and a northern site bounded by Hill, First, and Los Angeles Streets and Sunset Boulevard. The committee ultimately chose the northern site for the administrative complex and the Pershing Square/Normal Hill area for a cultural center. (Fogelson, 1967, pp. 262-4)

In 1927, the City and the Planning Commission adopted a civic center plan. (Figure 5.1) The final design was a compromise between two competing submissions. The first, submitted by Cook and Hall, Landscape Architects and City Planners, had a north-south orientation, extended to Sunset Boulevard, and incorporated the plaza as a landmark feature. The second, much grander proposal was submitted by Allied Architects, covered nearly a square mile, and had an east-west orientation that utilized the northern end of Bunker Hill as a landscaped park. (Fogelson, 1967, p. 264; Antczak, Mangan, \& Shute, n.d.)

Major Traffic Street Plan (1924)

Faced with mounting traffic congestion and the inability of private or public enterprise to institute necessary infrastructure improvements for the City's electric railways, by the mid 1920s city planners concluded that increased roadway capacity was necessary to facilitate the flow of vehicular traffic through Downtown. (Fogelson, 1967, p. 251) The major Traffic Street Plan of 1924 reflected this approach and specifically called for the widening of 1 st Street to facilitate crosstown traffic through Downtown. (Barholomew, Cheney, \& Olmsted, 1924, p. 36) (Figure 5.2)

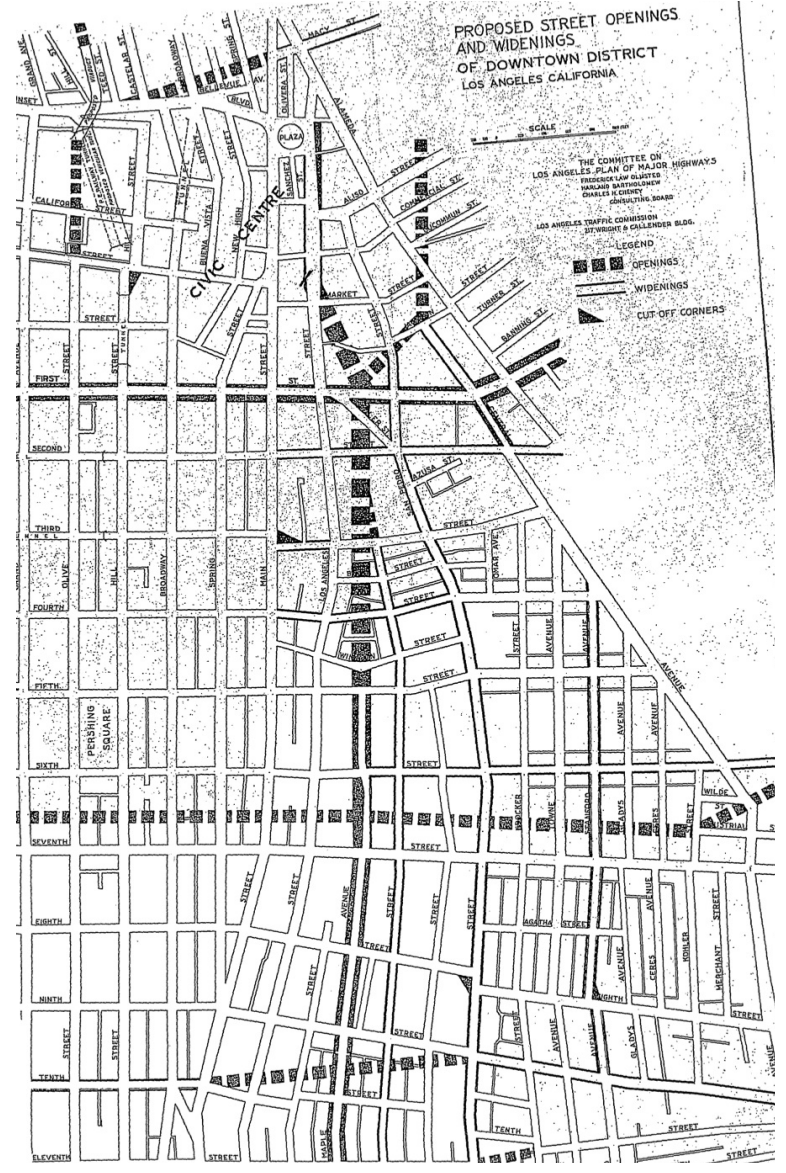

Figure 5.2. Proposed street openings and widenings in Downtown Los Angeles, from the 1924 Major Traffic Street Plan (Barholomew, Cheney, \& Olmsted, 1924, p. 36) 
Sequence of Redevelopment

The following series of photos

shows the sequence of pre-war

Civic Center redevelopment. The

first photo (Figure 5.3), taken

December 7, 1925, shows the

recently completed County Hall

of Justice. The Temple Block and

its surrounding buildings are still

intact and Spring Street still runs

diagonally from Main and Temple

Streets to First Street.

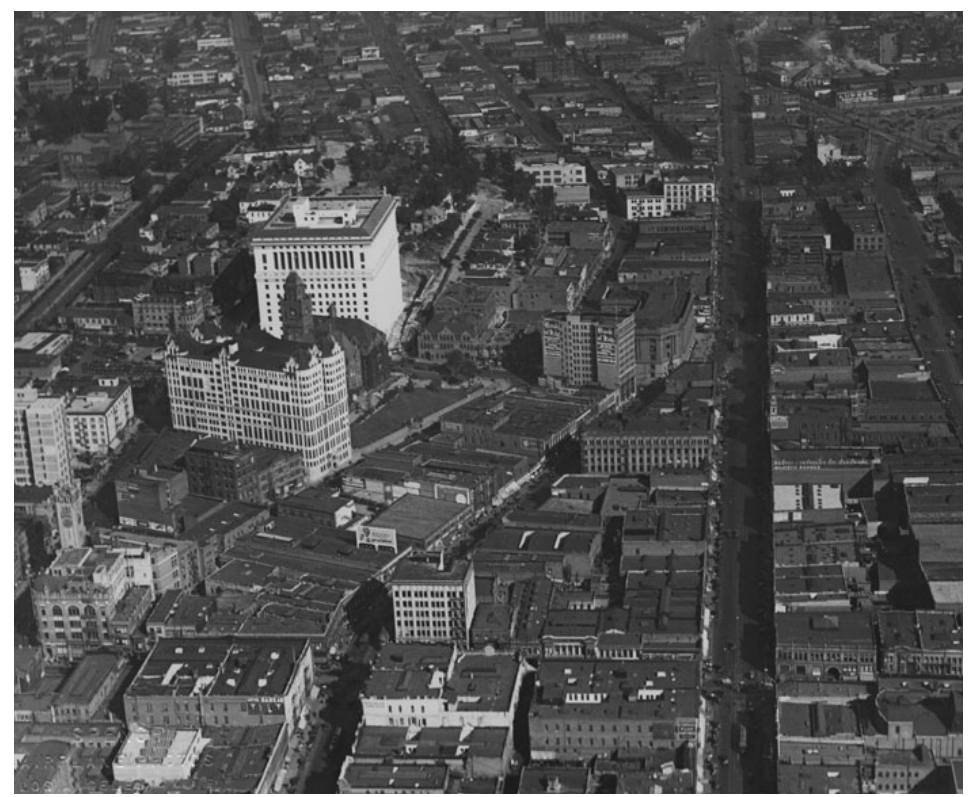

Figure 5.3. Aerial view looking north along Main Street at the Civic Center area prior to construction of City Hall, December 7, 1925 (Los Angeles Public

The second photo (Figure 5.4), Library)

dated August 22, 1931, shows the now-completed City Hall (1928) and the California State Office (1933) building under construction on the NW corner of Spring and First Streets. The 100 blocks of N. Main and N. Spring Streets have been cleared of almost all previously existing buildings and N. Spring has been straightened to terminate at Temple and New High Streets. The International Bank Building immediately north of City Hall and the Hall of Records

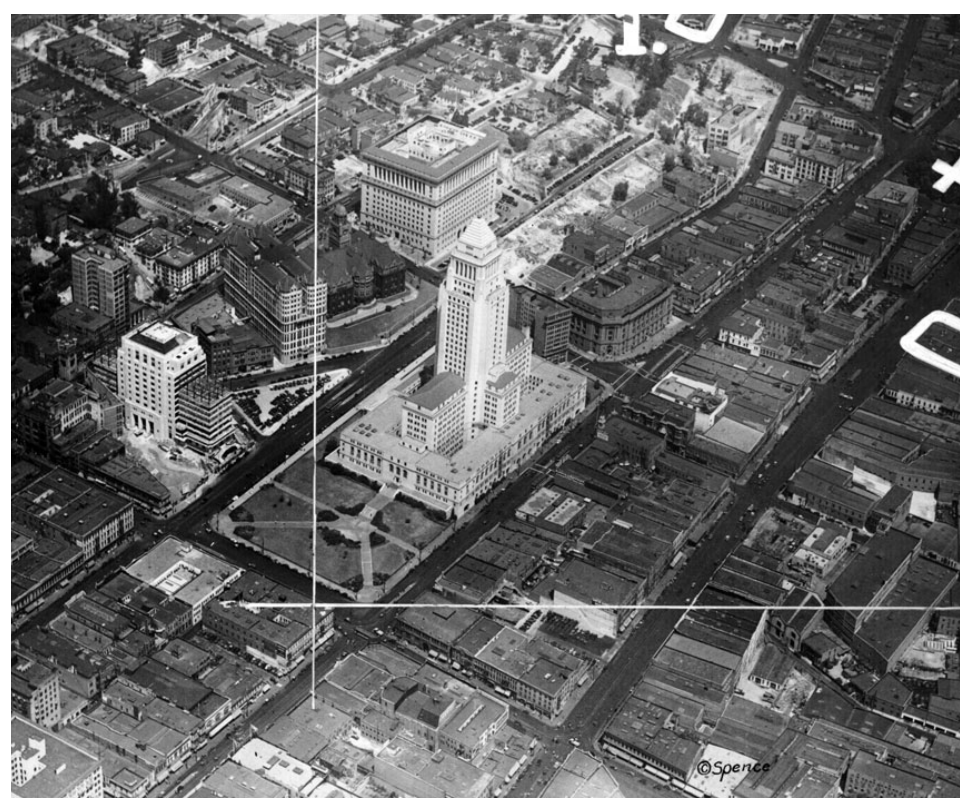

Figure 5.4. Aerial view of the Civic Center showing the completed City and the California State Building under construction, August 22, 1931 (The Examiner)

Building provide the only remaining evidence of the original alignment of Spring and New High Streets. 
The third, undated photo

(Figure 5.5) shows the area

north of Temple Street between

Main Street and the Hall of

Justice cleared for construction

of the Federal Courthouse.

The 1908 Post Office and the

St. Elmo Hotel were among

the structures cleared to make

way for the Federal Building.

The old County Courthouse

at Broadway and Temple was

also demolished at this time

due to damage sustained in

the Long Beach earthquake of

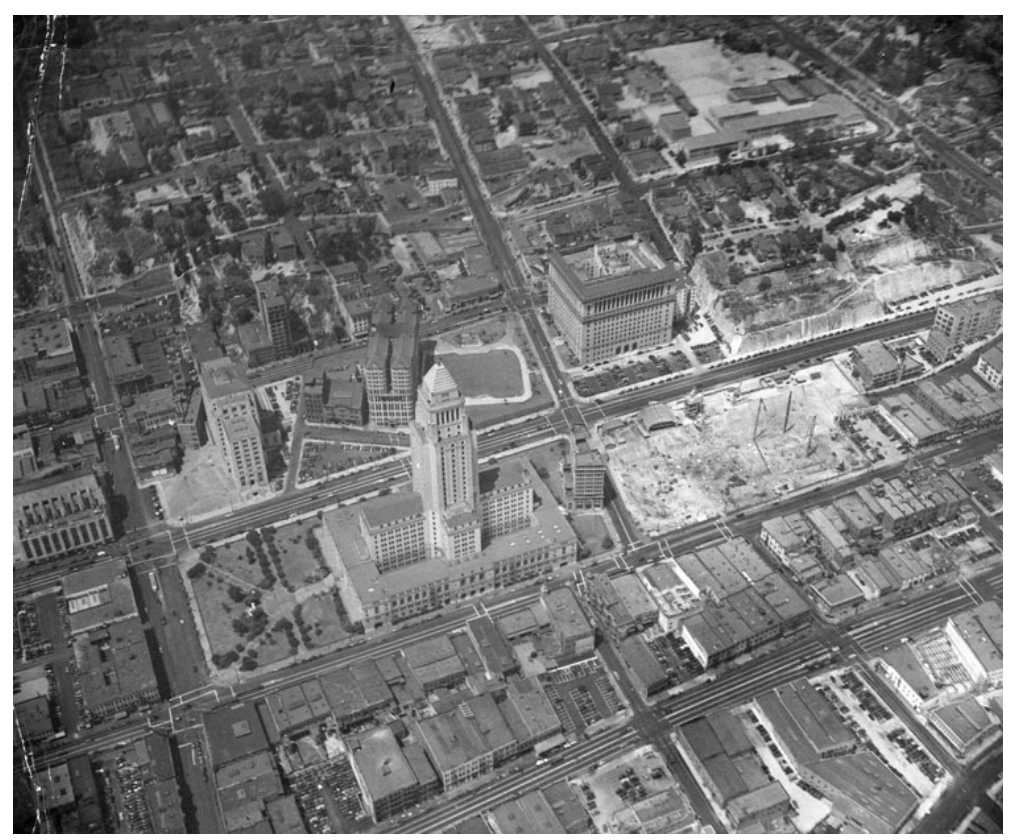

Figure 5.5. Aerial view looking west at the Civic Center showing Spring Street extended north of Temple Street, land cleared for the Federal Courthouse, and 1st Street being widened (Los Angeles Public Library) 1933. The recently completed

Times building (1935) is also visible just south of the California State Office Building along a steadily diminishing 1 st Street. Spring Street was also extended north of Temple Street at this time (Figures 5.6 and 5.7). To accommodate the new right of way, the Los Angeles Central Jail (1902-3) on Temple Street was demolished and the eastern face of Fort Moore Hill was shaved off. Union Station (1939) and the Terminal Annex Post Office (1938) were also completed around this period.

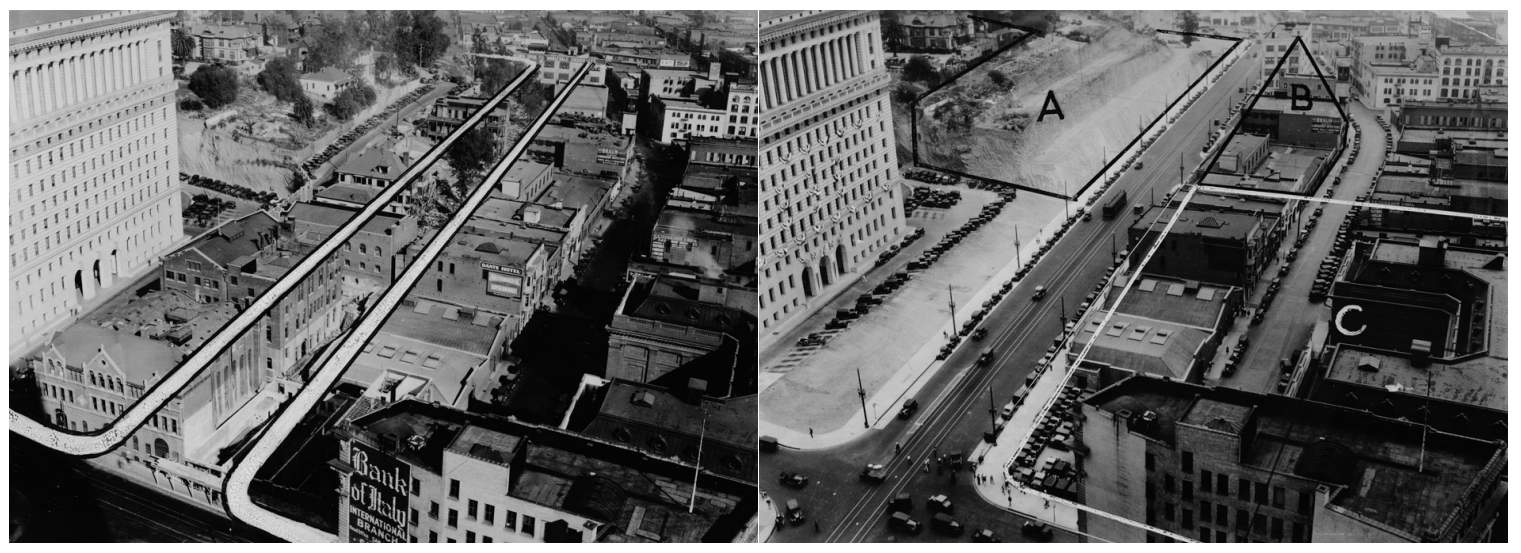

Figure 5.6. (Left) Area north of Temple Street prior to the extension of Spring Street (CHS)

Figure 5.7. (Right) Area north of Temple Street after Spring Street has been extended (CHS) 
The fourth, undated

photo (Figure 5.8) shows

the Civic Center after

completion of the Federal

Courthouse. The old

Times Building at the

NE corner of First Street

and Broadway has been

demolished to allow for

the widening of First

Street, as have been all

buildings between the

Hall of Records and the

California State Office

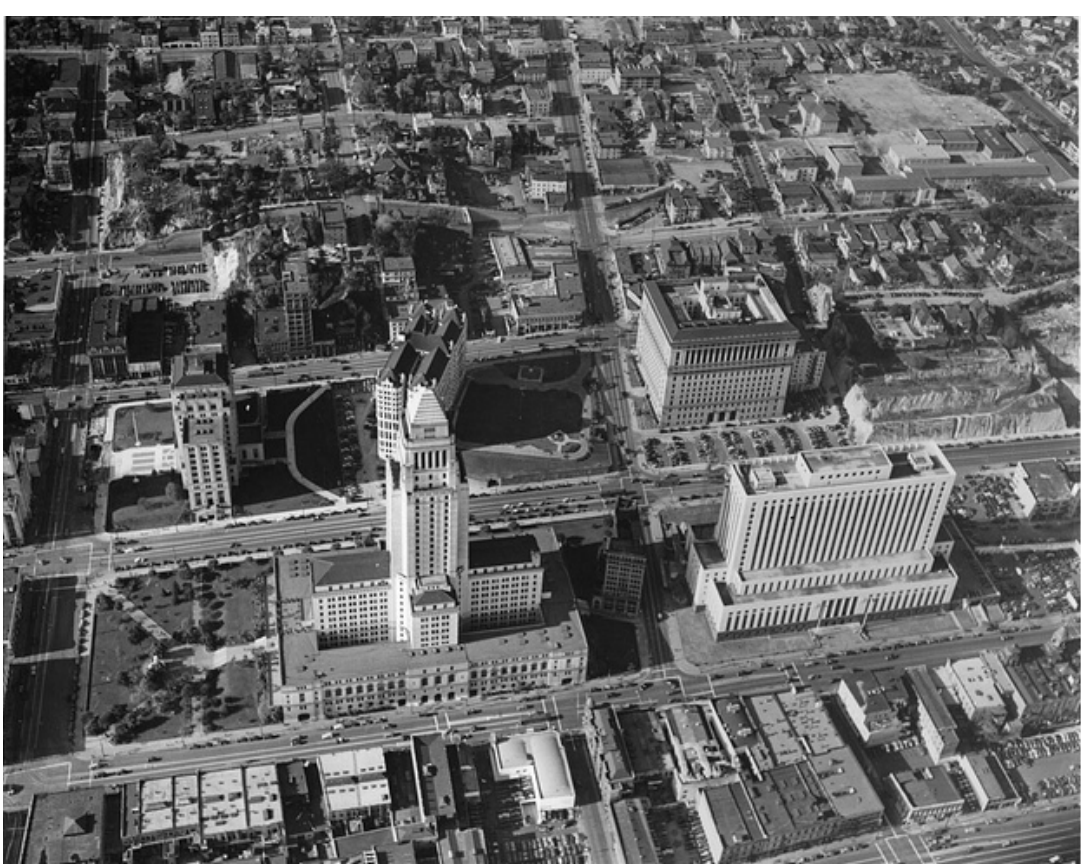

Figure 5.8. Aerial view looking west at the Civic Center showing the completed Federal Courthouse and 1st Street widened between Main Street and Broadway (Whittington)

Building. The subsequent

two undated photos (Figures 5.9 and 5.10) show First Street looking east from Hill Street before and after widening.

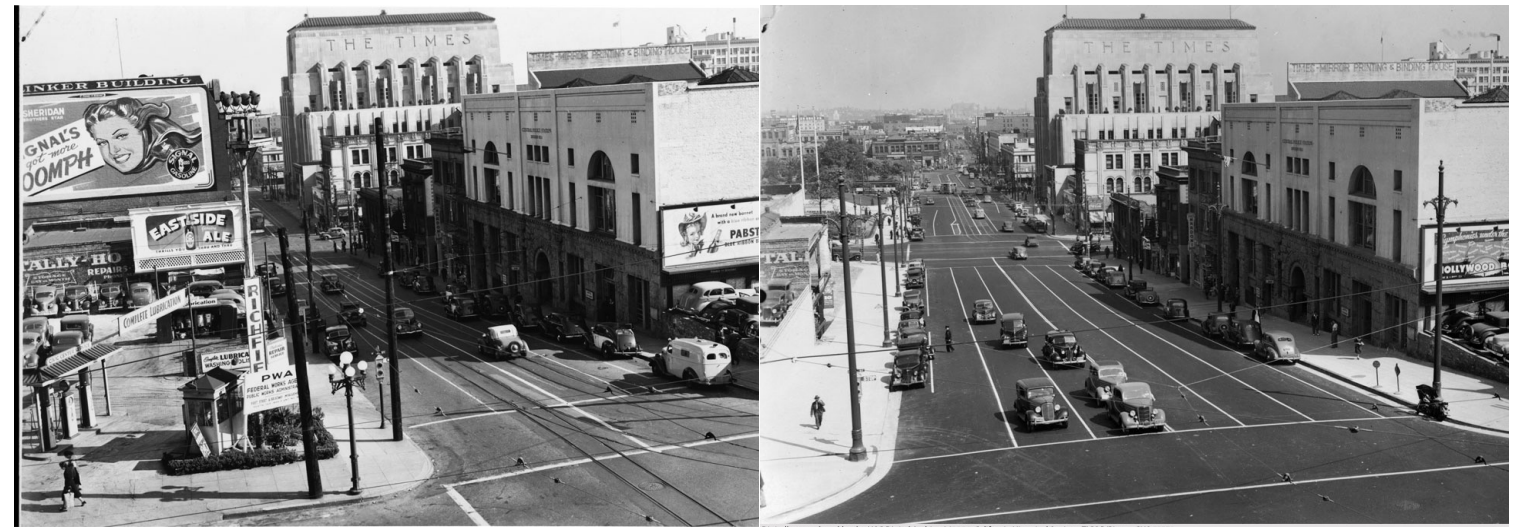

Figure 5.9. (Left) Looking east along 1st Street from Hill Street prior to widening (CHS)

Figure 5.10. (Right) Looking east along 1st Street from Hill Street after widening (CHS) 


\section{Post-World War II}

\section{Hollywood Freeway}

In 1949, the four level interchange that would soon connect the Hollywood and Santa Ana Freeways with the Harbor Freeway and the Arroyo Seco parkway was completed. (Figure 5.11) (Four Level Interchange, n.d.) On December 20, 1951, the Downtown Slot segment of the Hollywood Freeway opened to traffic through Downtown, connecting to the Santa Ana freeway to the east. The Slot was the third segment of the Hollywood Freeway to be built and cost

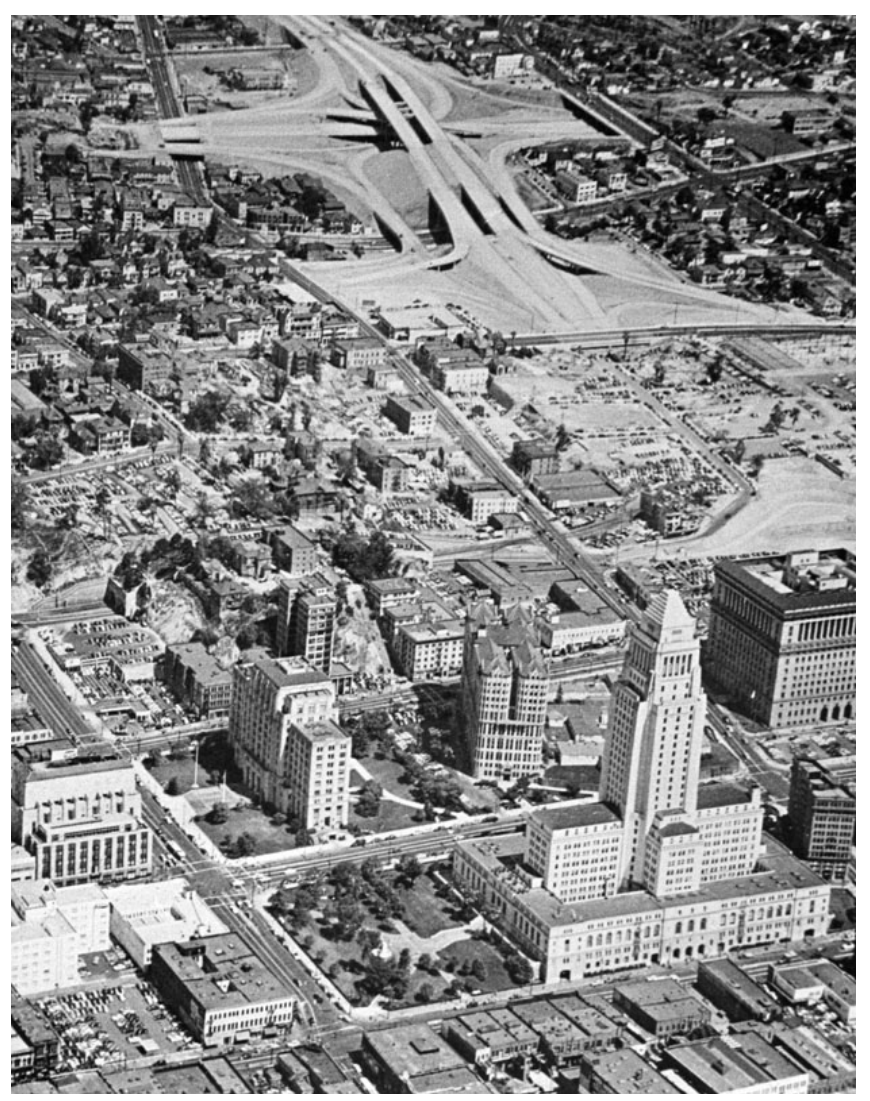

Figure 5.11. Aerial view of the four level interchange under construction (Los Angeles Public Library)
$\$ 6,358,000$ to construct. (Richardson, December 27, 2008; Richardson, December 20, 2011)

Construction of the freeway cut through Fort Moore Hill, destroying a wide swath of Los Angeles' historic fabric in the process, including the Los Angeles High School on N. Hill Street, the Broadway tunnel, the northern Hill Street tunnel, and the Baker Block on N. Main Street. The freeway also severed the Plaza to the north from the Civic Center to the south and fixed the Civic Center's eastwest orientation by blocking its northward expansion and opening up access to the northern end of Bunker Hill. (Several, 1997) 
In 1947, the city adopted a new Civic Center plan with an east-west axis and roughly bounded by Aliso Street on the north, 2nd Street on the south, Grand Avenue on the west, and Alameda Street on the east. (Figure 5.12) The first project was a new police headquarters, which later became known as the Parker Center. Construction of the new police headquarters displaced approximately 1000 Japanese Americans (who only recently resettled in the area after their WWII internment) and a quarter of Little Tokyo businesses. (Figure 5.13) (Several, 1997) During this period, 1st Street was also widened by roughly 20 feet between Main Street and San Pedro Street and San Pedro

Street was widened north of 1 st Street. (Hsu, 2011)

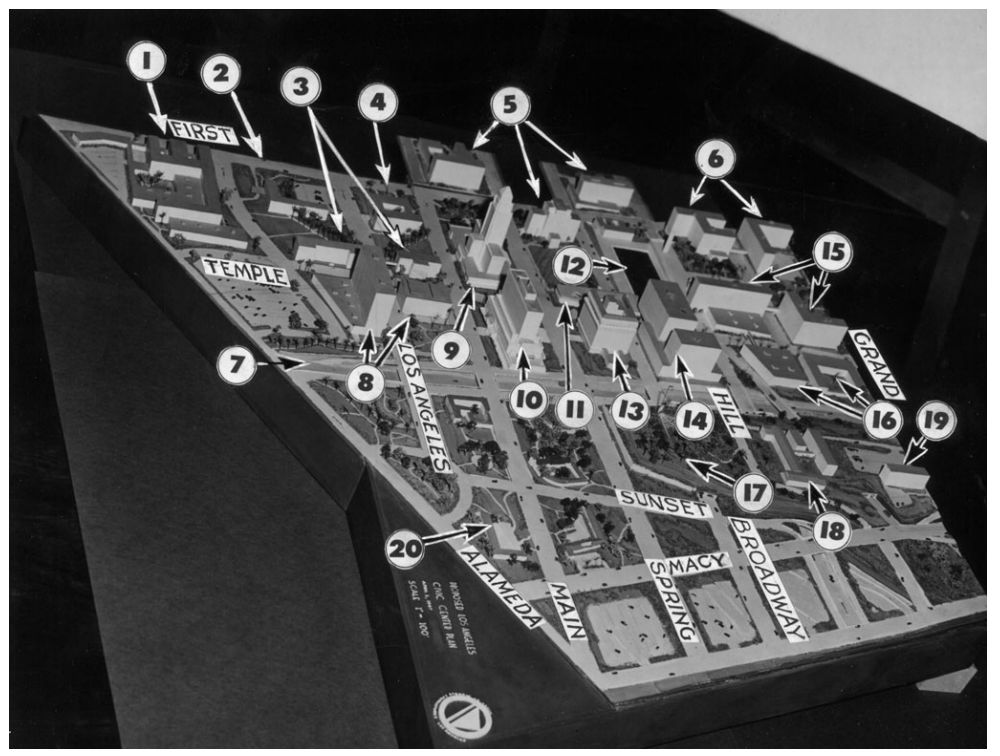

Figure 5.12. Model of the 1947 Civic Center Plan (The Examiner)

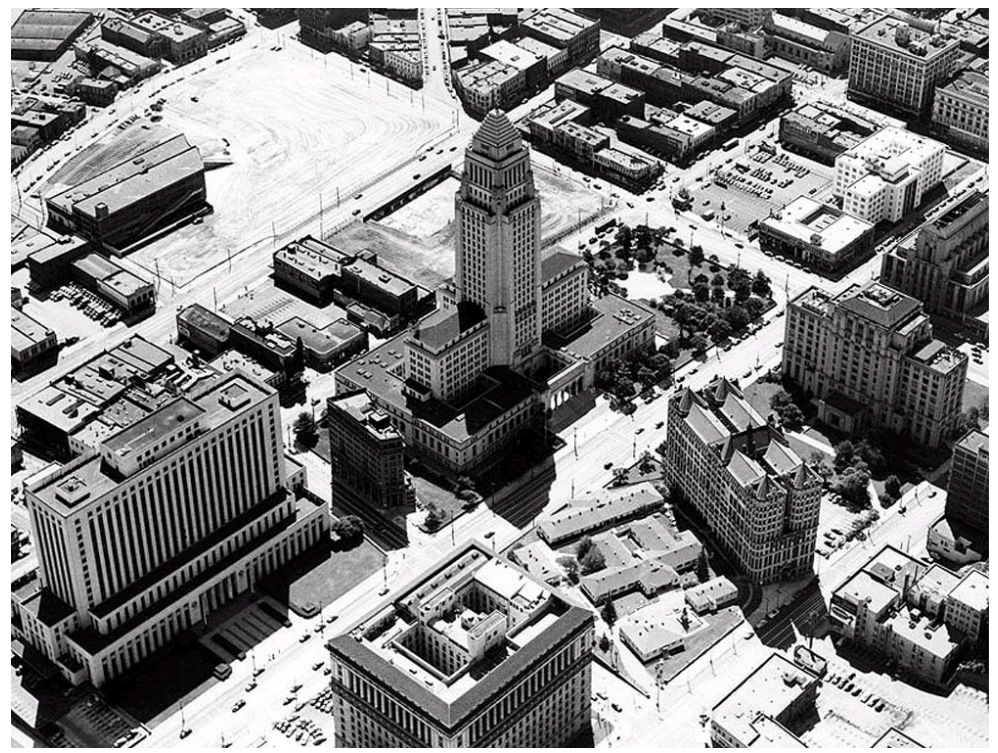

Figure 5.13. Aerial view looking southwest at the Civic Center showing land cleared for construction of the LAPD Headquarters

The following series of photographs show the sequence of post WWII Civic Center development west of Main Street. The first, undated photo (Figure 5.14) shows Court Hill sometime between 1933 and 1949, prior to construction of the Hollywood Freeway. In the foreground is the Court 


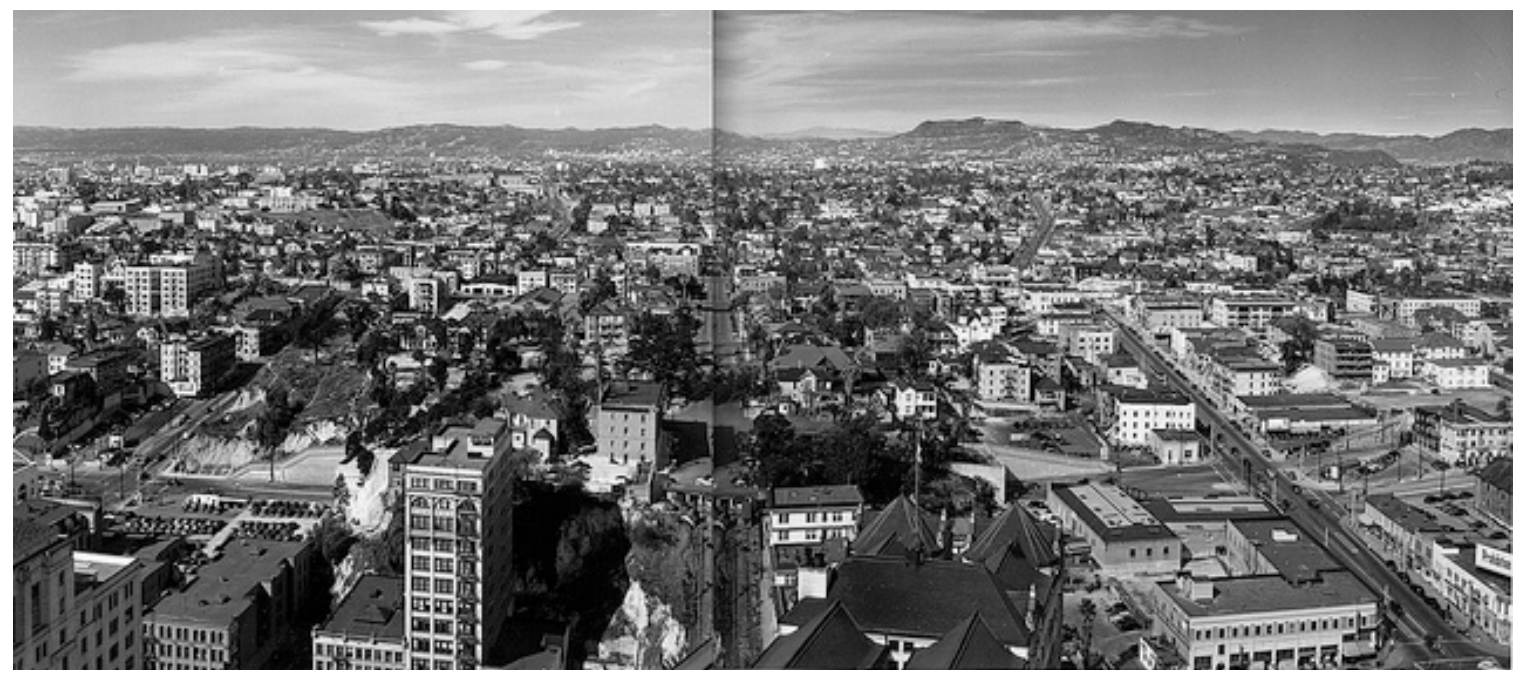

Figure 5.14. View west from City Hall of the north end of Bunker Hill prior to redevelopment. (CHS)

Flight incline railway and the Law Office building, both located on the west side of Broadway. The street directly in the center is Court Street. Temple Street is to the right side, 1 st Street is to the left side, and Hill Street runs across the center of the photo through the Hill Street Tunnel.

The second photo (Figure 5.15) depicts the same view as of June 24,1956. Court Hill between Broadway and Hill Street has been completely removed, along with Court Flight and the southern Hill Street tunnel. Court Hill between Hill and Grand Streets has been completely cleared and significantly graded. Construction of the new LA County Courthouse is well underway while the site of the LA County Hall of Administration is being prepared for construction. The already completed LA Law Library is visible at center left and the recently completed Hollywood Freeway is visible to the right.

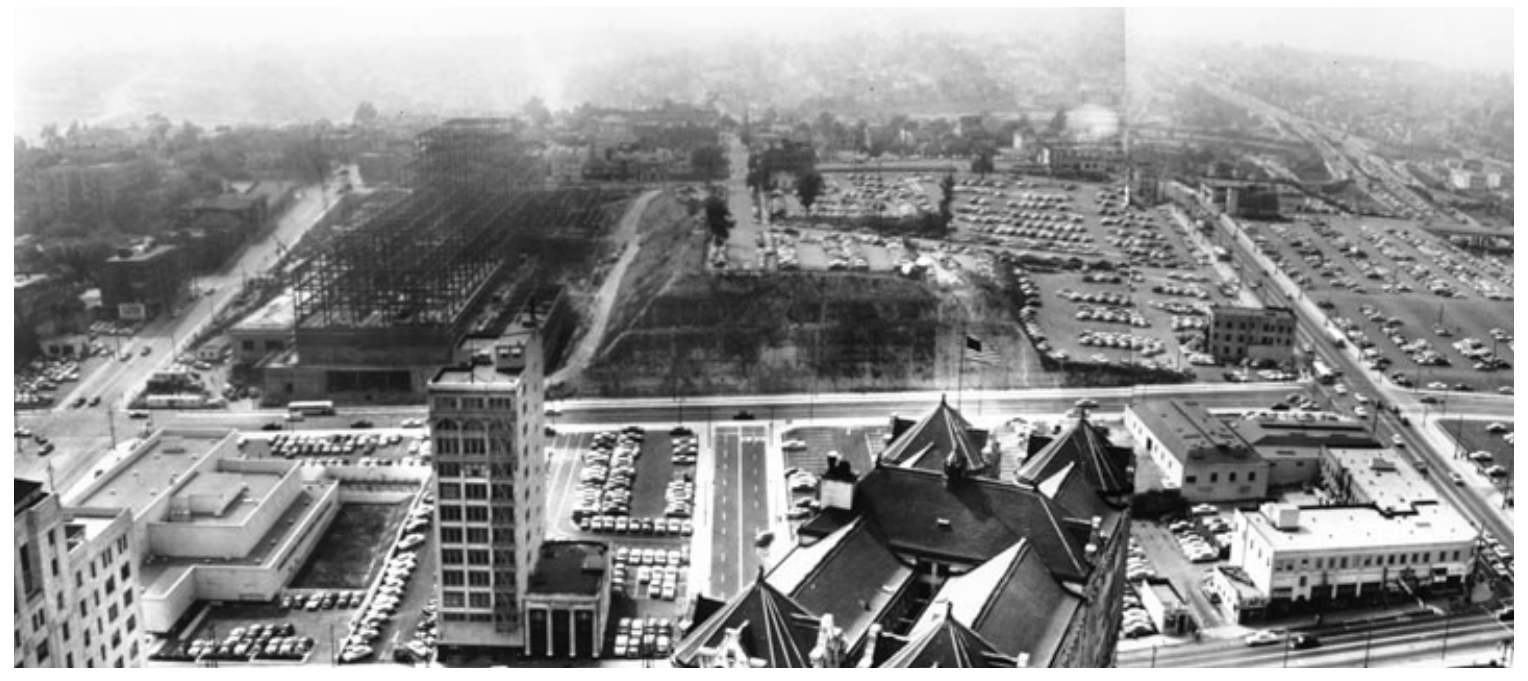

Figure 5.15. View west from City Hall of the north end of Bunker Hill showing Court Hill cleared and the LA County Courthouse under construction, June 24, 1956 (The Examiner) 
The third photo (Figure 5.16) was taken September 11, 1958, from the Chamber of Commerce building on Broadway between First and Second Streets. It shows the State Office Building No. 2 under construction in the foreground and the LA County Hall of Administration under construction in the background.

The fourth photo (Figure 5.17), taken January 20, 1970, shows City Hall East under construction in the bottom foreground and the Criminal Courts Building under construction just behind City Hall. Visible in the upper background are the Music Center and the Department of Water and Power, which were constructed in the prior decade. Three years later the old Hall of Records would be demolished, along with all traces of the pre-Civic Center architecture and topography of this area.

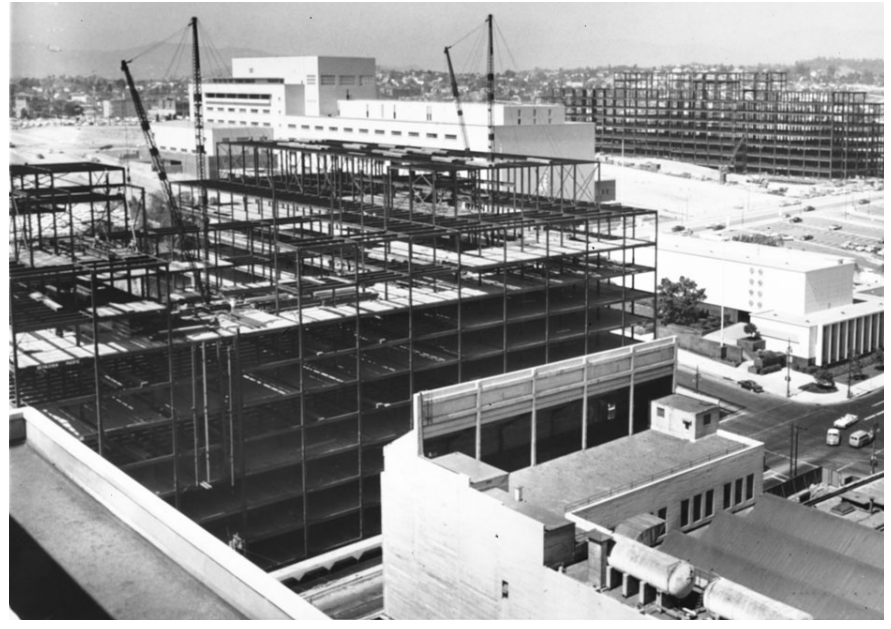

Figure 5.16. (Left) View looking northwest over the intersection of 1st and Broadway showing the construction of State Office Building No. 2 (foreground) and the LA County Hall of Administration (background), September 11, 1958 (The Examiner)

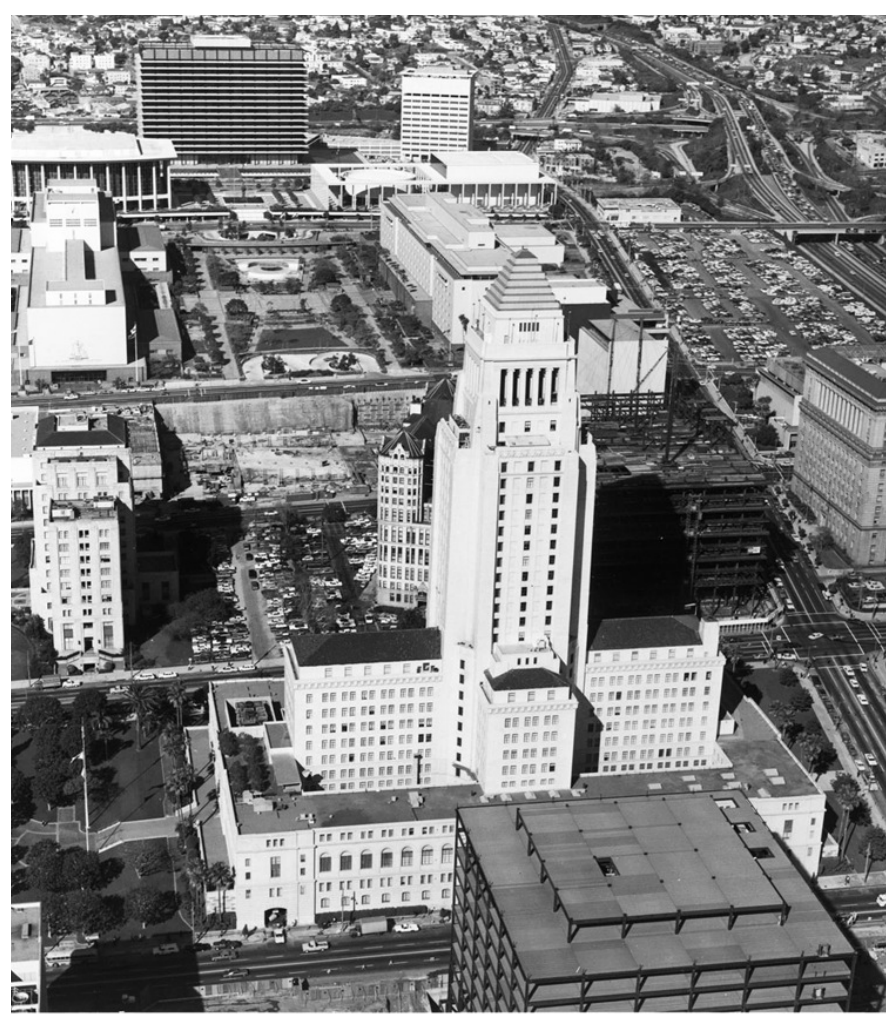

Figure 5.17. View west over City Hall showing the construction of City Hall East (foreground) and the Criminal Courts Building (behind City Hall), January 20, 1970 (CHS) 
Chapter 6. Current Conditions: Recent and Proposed Development 


\section{Introduction}

Redevelopment within the Civic Center continued through the remainder of the 20th century, filling the remaining parcels east of Main Street and north of Temple Street. New buildings added during this period include the Los Angeles Mall (1975), the Metropolitan Detention Center (1988), and the Edward R. Roybal Federal Building (1991). The Ronald Reagan State Office Building (1990) was also built during this time at 3rd and Spring Streets, where its height, building footprint, and street wall massing dwarfs the surrounding context of the Historic Core. In the first decades of the 21st century, new development like the Caltrans District 7 Building and the LAPD Headquarters has extended the Civic Center southward to 2 nd Street. As a result, 2nd Street has begun to replace 1st Street as the border between the Historic Core and the Civic Center. (Project Restore, 2006, p. 41)

Several new completed and proposed projects are reshaping the north end of Downtown. These projects include large-scale redevelopment proposals, new transportation infrastructure, district designations and master strategic plans, civic and community buildings, historic preservation and adaptive reuse projects, and residential and neighborhood improvement developments. This chapter details completed and proposed development projects that will affect and inform any comprehensive planning efforts for the northern part of Downtown. 


\section{Large-Scale Redevelopment Proposals and Master Plans}

Park 101

Park 101 is a proposal to build a cap over the half-mile length of the 101 Hollywood Freeway in downtown Los Angeles and construct a series of parks on top of it. (Figure 6.1) The project aims to reconnect the city's historic El Pueblo district north of the freeway with the Civic Center, Music Center, and other districts to the south of the freeway. The project is currently under study with funding provided by the Southern California Association of Governments' (SCAG) Compass Blueprint Demonstration Project Program and is being considered for implementation by the Los Angeles Community Development Department and Caltrans. (AECOM, Park 101, 2012)

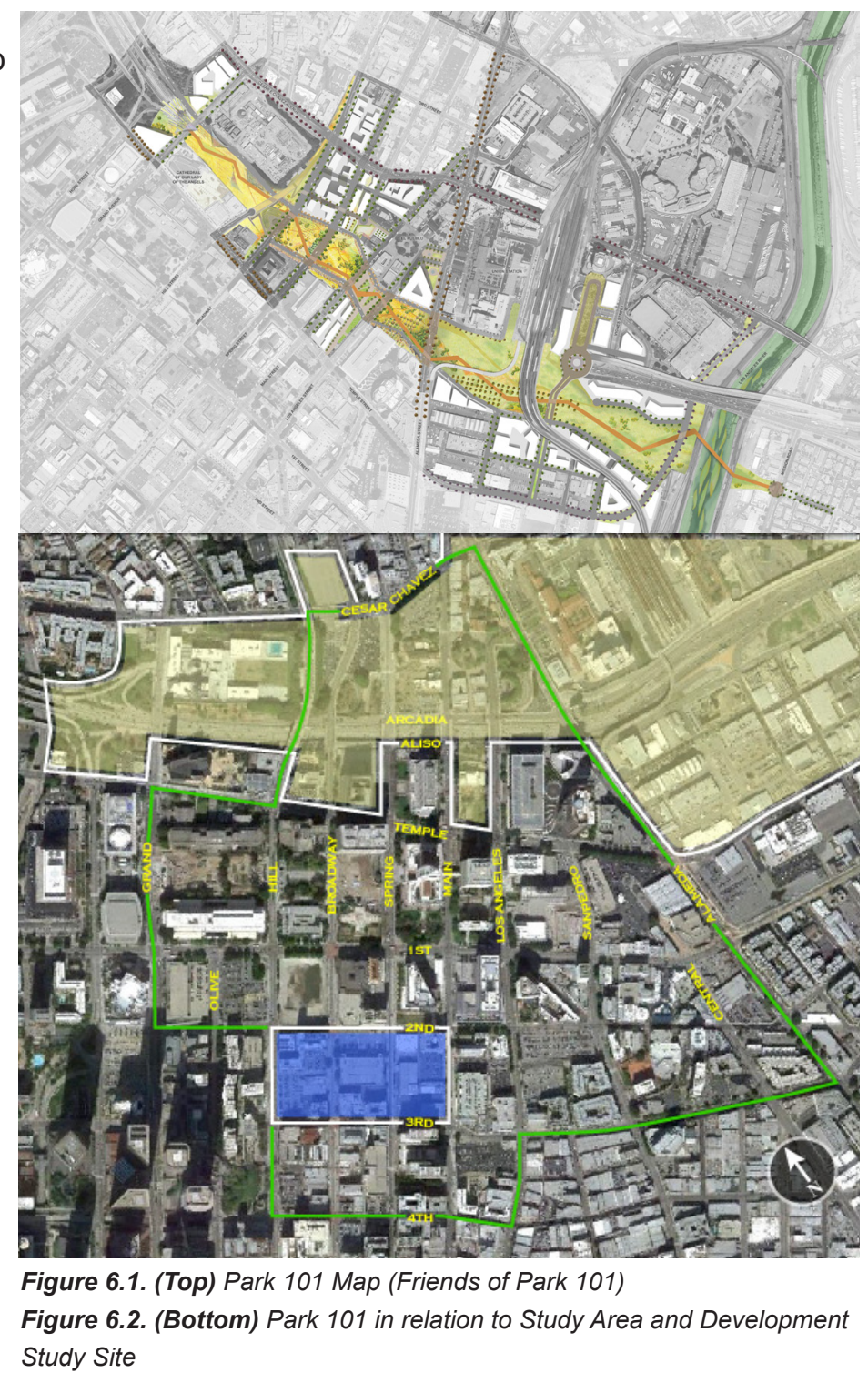

Project Restore Study Site

Project Restore is non-profit organization dedicated to historic preservation and restoration in the City of Los Angeles. While most of the projects the organization has undertaken have focused on individual buildings or landmarks, Project Restore has also completed two large-scale, complimentary strategic master plans with direct relevance to the present study area. (Project Restore, 2010) 
Civic Crossroads is a planning and design initiative focusing on restoring the links between the Civic Center, El Pueblo de Los Angeles, and the Historic Core. Civic Crossroads centers on City Hall and Main and Spring Streets between 2nd Street and Cesar Chavez Boulevard. The plan builds upon the "Ten Minute Diamond" Civic Center plan adopted by the Los Angeles City Council in 1997 and identifies the area around City Hall as a key crossroads between El Pueblo to the north and the Historic Core to the south. Recommendations include the improvement of Main and Spring Streets as part of a larger district plan, a new design for City Hall Park, and the creation of gateways at both 2nd Street and Aliso Street. (Project Restore, 2006, pp. 35-44)

The First Street Now! Plan focuses on the two-mile stretch of 1st Street between Bunker Hill and Boyle Heights and aims at improving walkability and the urban character along this corridor. Key components of the plan include extending City Hall Park's public space across 1 st Street to join the LAPD headquarters plaza and the development of 2 nd Street as a residential and shopping corridor running parallel to and complementing the 1st Street corridor. (Figure 6.3) (Project

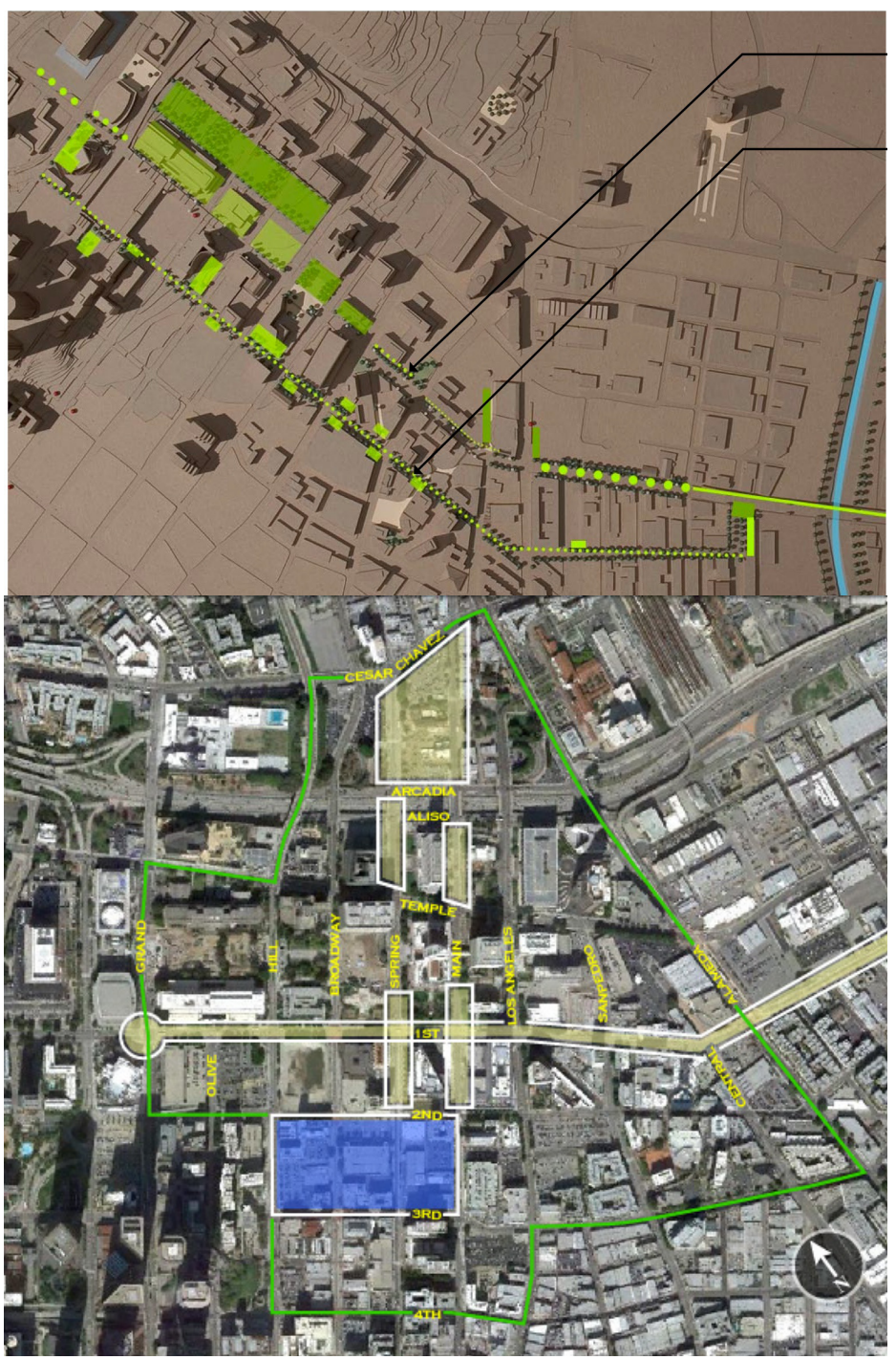

Figure 6.3. (Top) First Street Now! diagram showing treatment of 2nd Street (Project Restore 2005, p. 18)

Figure 6.4. (Bottom) Civic Crossroads and First Street Now! in relation to the Study Area and the Development Study Site

Restore, 2005, Ch. i) 
Grand Avenue Project

The Grand Avenue Project is a $\$ 3$ billion project being developed by

Related Companies at the northern end of Bunker Hill. (Figure 6.5)

Specific components of the project include: a new museum at the southwest corner of Grand Avenue and 2nd Street; a large mixed-use development occupying the two city blocks west of the new courthouse; and redevelopment of the 12-acre park between City Hall and the Music Center.

The Los Angeles City Council and the Los Angeles County Board of Supervisors approved the project in February of 2007. The Civic Park and the Broad Museum portions of the project are currently under construction. However, groundbreaking for Phase I of the mixed-use development, which will include two luxury residential towers, a boutique hotel and 250,000 square feet of retail, has been repeatedly delayed due to financing issues and the downturn
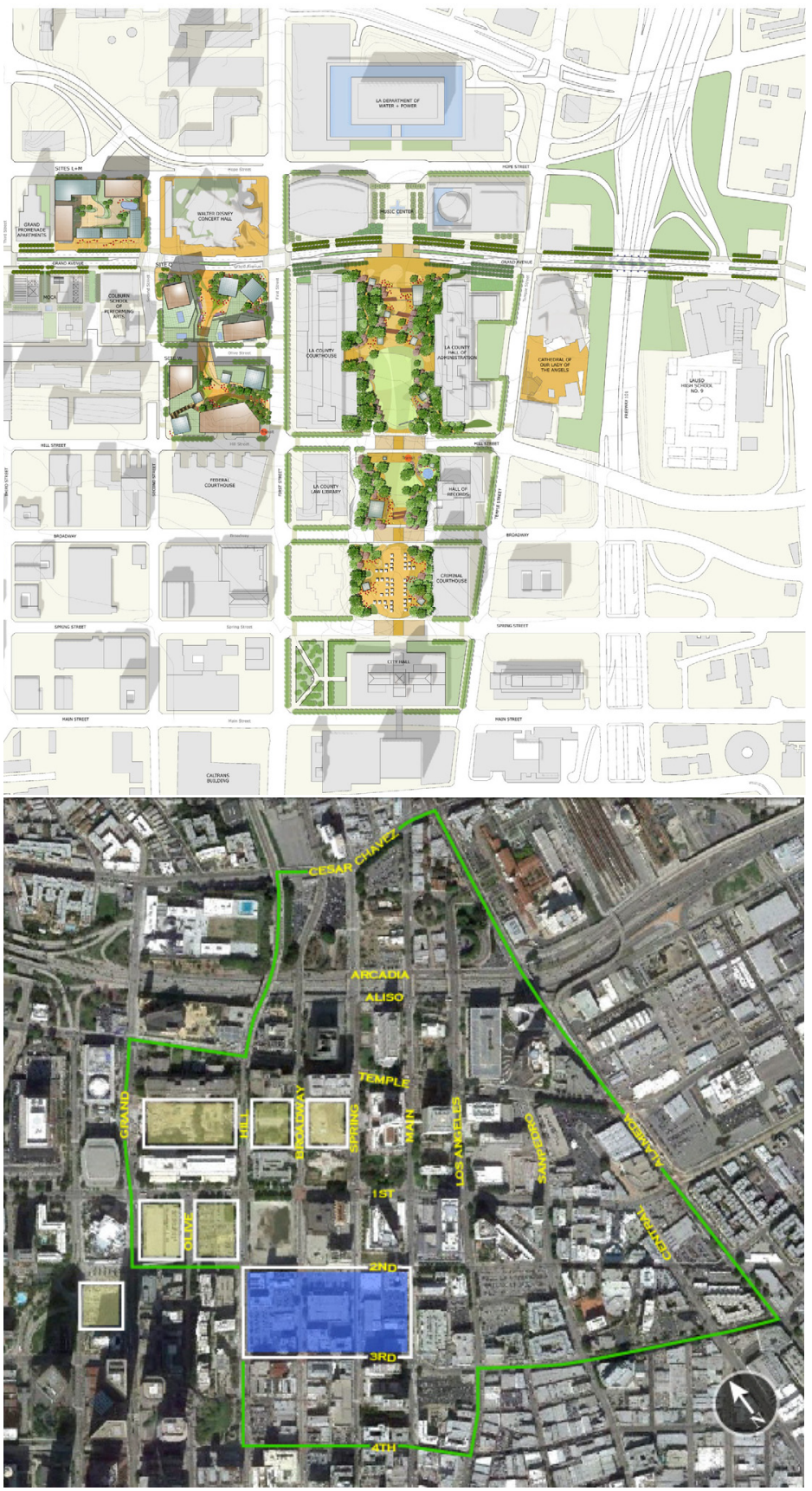

Figure 6.5. (Top) Grand Avenue Map (Related Companies)

Figure 6.6. (Bottom) The Grand Avenue Project in relation to the Study Area and the Development Study Site

in the economy. (Vaillancourt, 2011;

Grand Avenue Project, n.d.) 


\section{Civic Center Developments}

\section{Federal Courthouse}

In January 2012, it was announced that the Federal government would proceed with the construction of the long-delayed replacement for the old 1939 Federal Courthouse. (Figure 6.8) The new courthouse will be built at 1st Street and Broadway on the former site of the Junipero Serra State Office Building, which was torn down in 2007 after sustaining damage in the 1994 Northridge earthquake. The project has been scaled down from the original 17 -story proposal, which rose in cost to $\$ 1.1$ million dollars. The current project is anticipated to cost $\$ 400$-million to build and will include 600,000 -square-foot of space with 24 courtrooms, 32 judges' chambers, and 110 on-site parking spaces. Construction is anticipated to begin in the last quarter of 2012

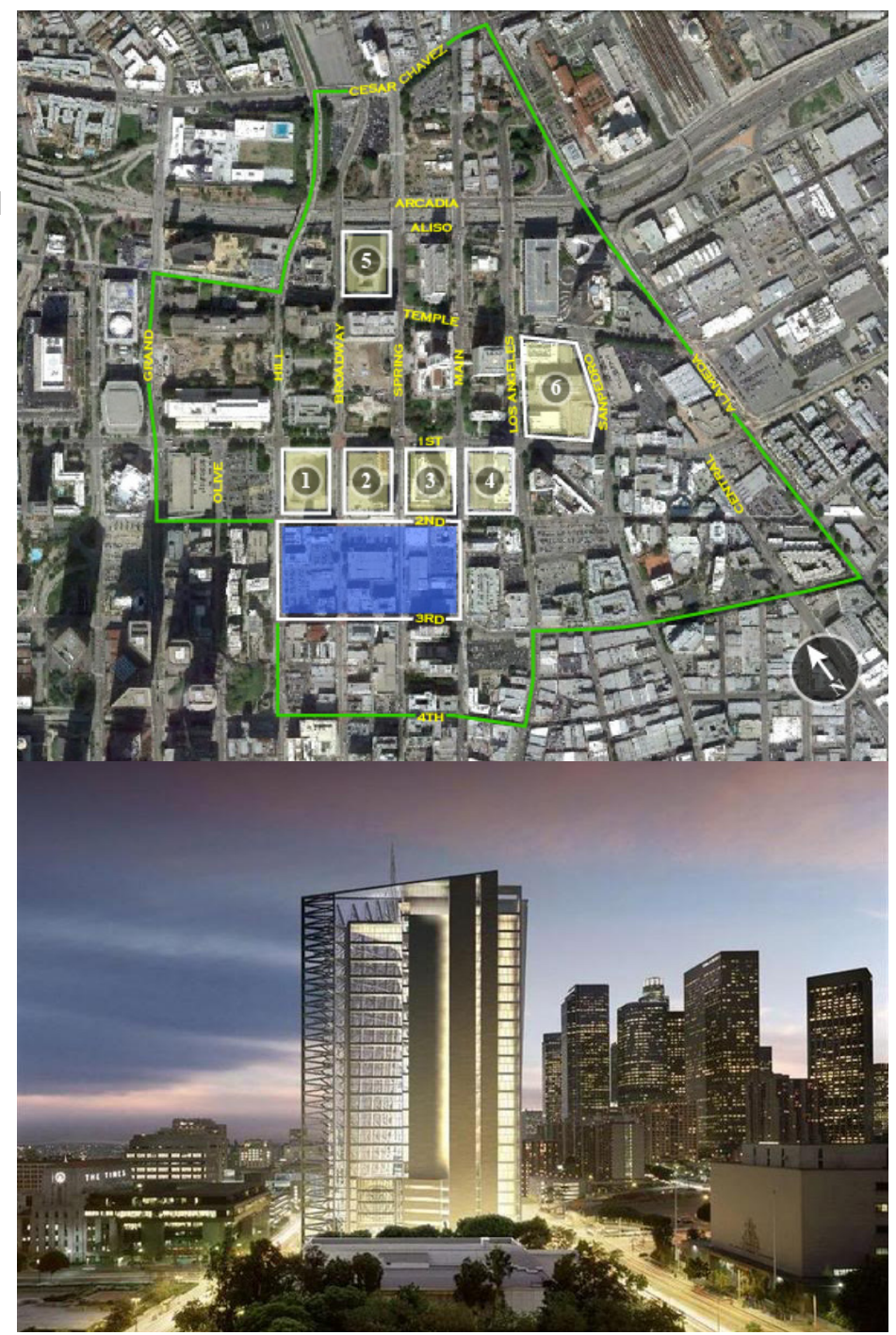

Figure 6.7. (Top) Civic Center developments in relation to the Study Area and the Development Study Site: (1) Federal Courthouse, (2) Times Mirror Square, (3) $L A P D H Q$, (4) Caltran District $7 H Q$, (5) Hall of Justice, and (6) Parker Center. be ready for occupancy no later than Figure 6.8. (Bottom) Federal Courthouse (Perkins \& Will) March 2016 (Brasuel, 2012) 
Times Mirror Square

Times Mirror Square is an office complex of five buildings, including the original 1939 Times Building and the 1941 Times Mirror Building. The complex includes 750,000 square feet of usable space, but is currently partially vacant and underutilized. In June 2008, Sam Zell, chairman of the Tribune Company, which owns the Times, issued an RFP for the sale of Times Mirror Square. However, the property was taken off the market in 2009 due to the depressed real estate market and the Tribune Company's entrance in bankruptcy proceedings. Since then, the company has continued to seek tenants, including the Los Angeles City Employees' Retirement System (LACERS), which will begin a ten-year lease on 35,000 square feet of space starting in the summer of 2012. (DiMassa, 2008; Richardson, February 25, 2009; Vincent, 2012)

\section{Los Angeles Police Department (LAPD) Headquarters}

The new LAPD Headquarters, completed in 2009 at a cost of $\$ 427$ million, has been a significant addition to the Civic Center. The 10-story building contains 491,000 square feet of space and was designed by DMJM architects (now part of AECOM). The design utilized setbacks, required for security reasons, to create a series of open spaces to complement the surrounding pedestrian environment. The landscaping by Melendrez features colorful, drought resistant plants. (Richardson, September 3, 2009; AECOM, Los Angeles Police Department (LAPD) Headquarters, 2012)

As part of the LAPD Headquarters development, a new LAPD Motor Transport Division garage was also built on Main Street between Second and Third Streets. The 300,000 square foot, 5-story concrete structure includes: an 800 car employee parking structure; a mechanics' garage, car wash, and refueling station; and a retail component along Main Street. (JFAK Architects, n.d.)

\section{Caltrans District 7}

The Caltrans District 7 building, completed in 2005, is another significant addition to the Civic Center. The 13-story building cost $\$ 165$ million to build and contains 716,200 square feet of space, with underground parking for 1,142 vehicles. The building boasts an innovative and environmentally sensitive design by Morphosis featuring a forty-foot, forward-canted super- 
graphic "100" denoting the building's Main Street address, a large plaza facing City Hall, and a shifting building skin of perforated aluminum panels that are timed to open and close with the movement of the sun and weather conditions. (Caltrans District 7 Headquarters, n.d.; California Department of Transportation, n.d.)

\section{Hall of Records}

The 1925 Hall of Records building, which sustained heavy damage in the 1994 Northridge earthquake, is currently undergoing a $\$ 231$ million rehabilitation that includes seismic improvements, elevator upgrades, new electrical and mechanical systems and connections to sewage, water and gas systems. A new underground 1,000-space garage will be built on the north side of the building and the granite exterior will receive a high-pressure washing. The renovated building will house the Sheriff's Department, the District Attorney's office, and other county agencies. (Guzman, Regardie, \& Vaillancourt, 2012)

\section{Parker Center}

The Parker Center served as the headquarters for the LAPD from 1955 to 2009, when the LAPD moved into its new headquarters at 1st and Main Streets. Since then, the 398,000-squarefoot, Welton Beckett-designed building has sat mostly empty, with the exception of about 150 employees who are still working out of the deteriorating building. (LA Downtown News, 2012)

In June 2010, Councilwoman Jan Perry introduced a motion to consider a land swap between the city-owned Parker Center site and the federally-owned, 3.5 acre parcel at 1st and Broadway. At the time, the proposed Federal Courthouse at the Broadway site appeared ready to be cancelled and the City was exploring the possibility of gaining control of the parcel located adjacent to the proposed Grand Avenue Project site. However, it now appears that the Courthouse will be constructed, rendering a potential land swap moot. (Richardson, July 23, 2010)

Regarding the Parker Center site, according to LA Downtown News (2012), "The city has proposed undertaking an Environmental Impact Report that would study five options for the site, including adaptive reuse of the building, partial demolition and renovation, and demolition and replacement with a temporary parking lot. That plan remains on hold and without a timeline." 
In late 2011, the City completed construction of a 300 space underground parking garage at the corner of 1st Street and Judge John Aiso Street in Little Tokyo. A 51,830 SF, landscaped plaza was constructed on top of the structure at street level and will feature future city-leased retail kiosks. The new open space has been christened Toriumi Plaza, after Reverend Howard Noboru Toriumi, a local community activist who founded what would later become the Little Tokyo Community Advisory Council (LTCAC). (Yen, October 13, 2011)

\section{Transportation Projects}

\section{Regional Connector}

The Regional Connector is a 1.9 mile subway tunnel that will connect and consolidate the Metro Gold, Blue, and Expo Lines into two lines: one traveling between Santa Monica and East LA and the other traveling between Long Beach and Claremont. (Figure 6.9) These lines will also connect with the Metro Red Line (to North Hollywood) and Purple Line (to Wilshire/ Western and later to West LA) at the 7th Street/Metro Center station. (Los Angeles County Metropolitan Transportation

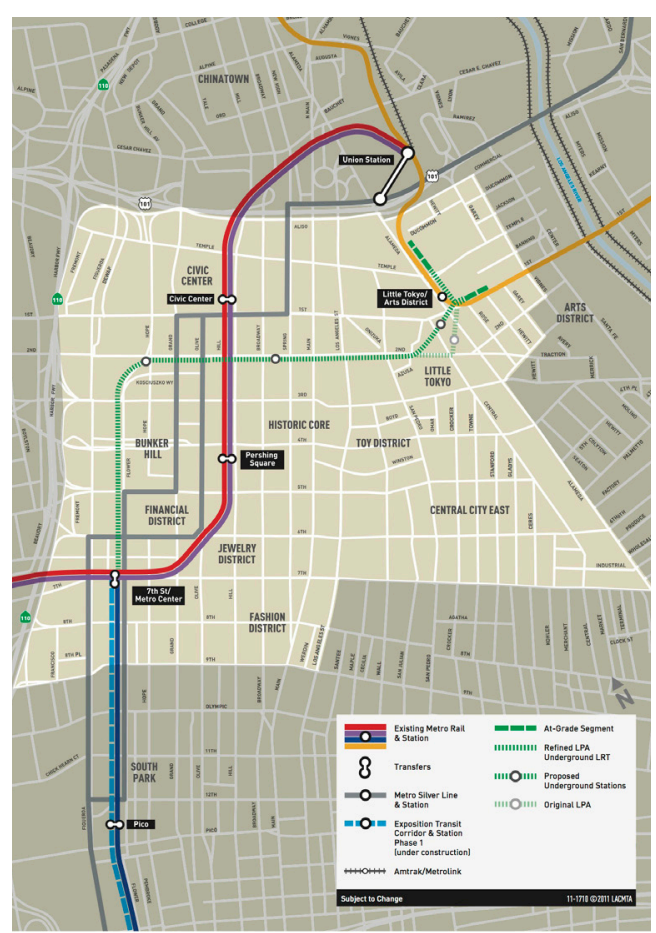

Figure 6.9. Regional Connector Transit Corridor Map (Los Angeles County Metropolitan Transportation Authority, 2012)
Authority, 2012)

On April 26, 2012, the Metro Board of Directors certified the Final Environmental Impact Statement/ Report (EIS/EIR) for the $\$ 1.37$ - billion project. The project could begin construction in 2013 and is scheduled to be complete in 2019. The project includes new stations at 2nd \& Grand Streets, 2nd \& Broadway, and 1st \& Central Avenue in Little Tokyo, with the potential for a future infill station at 5 th \& Hope Street in the Financial District. (Sotero, 2012) Due to budgetary constraints in the construction of 


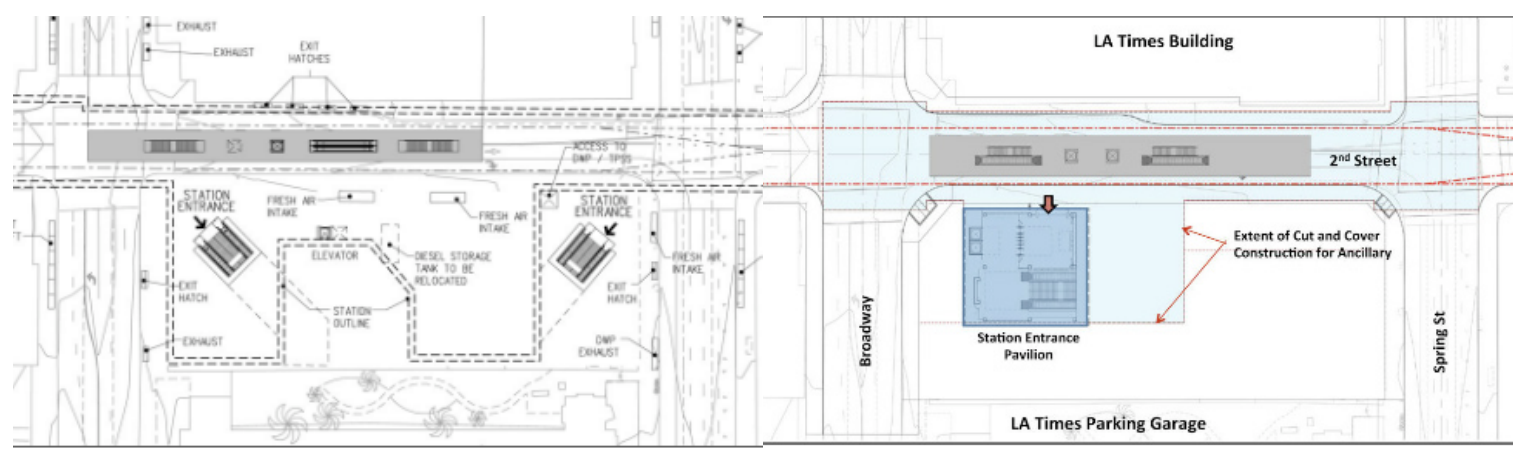

Figure 6.10. Diagram of Broadway and 2nd Street Station showing dual portal option (Left) and single portal option (Right) (Richardson, September 17, 2011)

the Regional Connector, plans for the two portal subway entrance with below ground ticketing at the 2nd \& Broadway Station have been scaled down to a single portal with street level ticketing.

(Figure 6.10) (Richardson, September 17, 2011)

\section{Downtown Streetcar}

On March 13, 2012, the Los Angeles City

Council and the Community Redevelopment Agency selected Alternative 7 as the Locally Preserved Alternative for the Downtown Streetcar. (Figure 6.11) Once the project is approved by Metro, it will then need to receive CEQA and NEPA environmental clearances. (Metz, 2012) The project is anticipated to cost $\$ 106$ million to $\$ 137$ million depending on which route is ultimately selected. A groundbreaking is expected in 2014, with construction anticipated to take two years. (Guzman, Regardie, \& Vaillancourt, 2012)

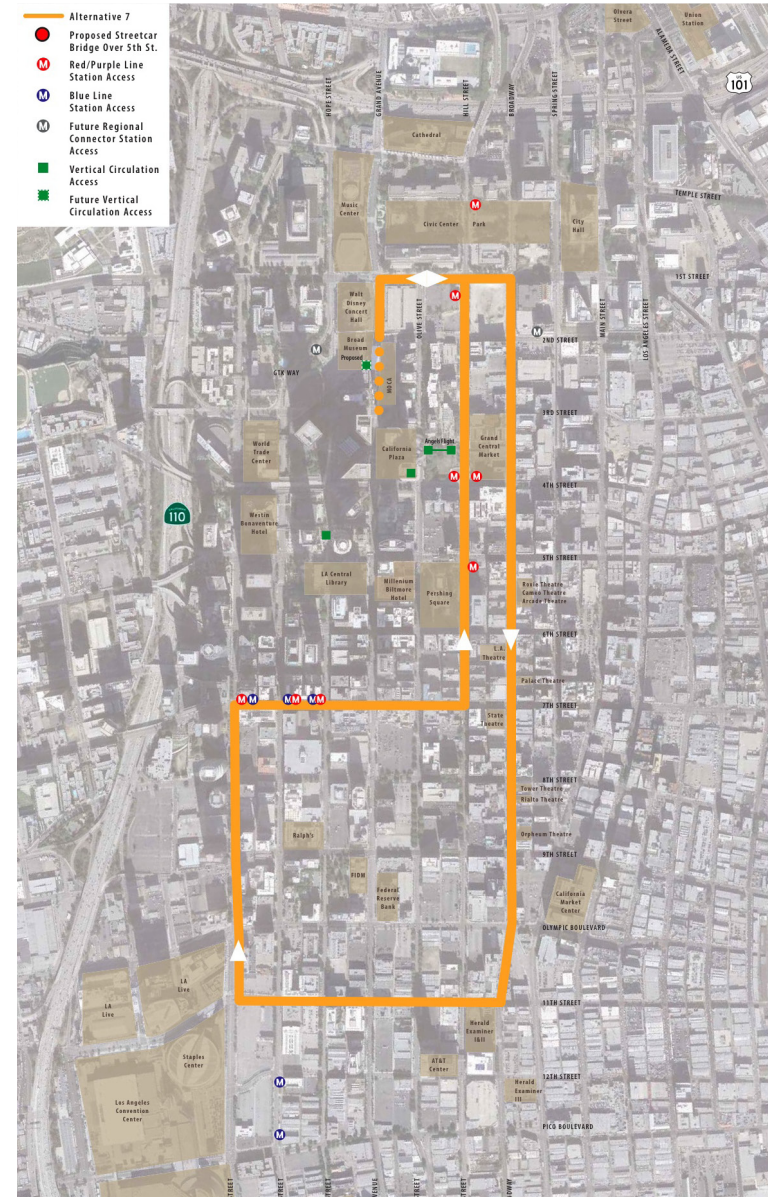

Figure 6.11. Metro Streetcar map (Los Angeles County Metropolitan Transportation Authority, 2012) 


\section{Spring Street Bike Lanes}

In November of 2011, the Los Angeles Department of Transportation installed 1.5 miles of green southbound only bike lanes along Spring Street between Cesar Chavez Avenue and 9th Street. Installation cost $\$ 150,000$, required the removal of two lanes of traffic along Spring Street, and is intended to create a more "complete street" for multi-modal travel along the corridor. The appearance of the green, traffic-rated paint used for the lanes has generated complaints from filmmakers who frequently use the street for film shoots. (Los Angeles Department of Transportation, n.d.)

\section{Other Developments}

\section{Medallion}

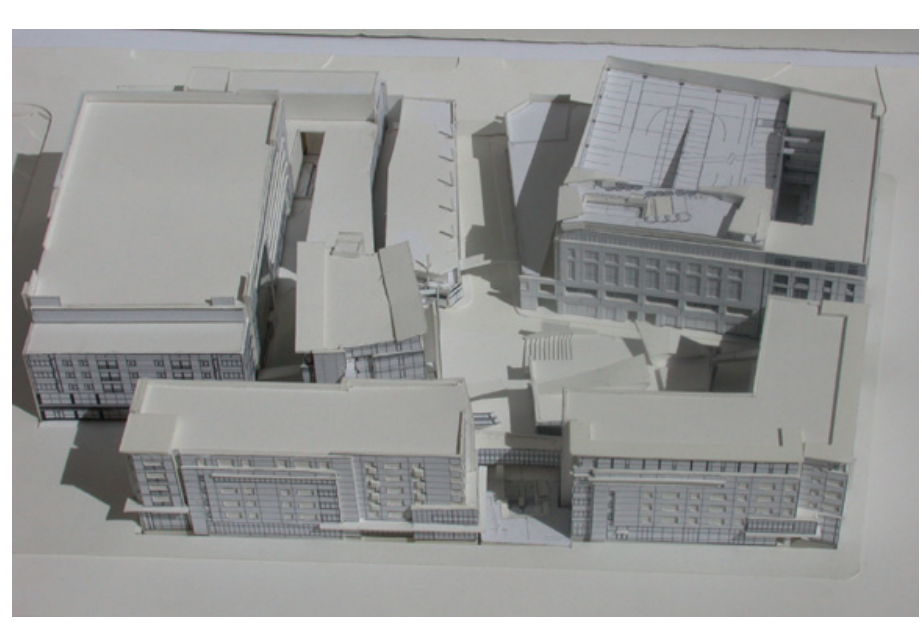

Figure 6.12. The Medallion Apartments (M2A Architects)
Medallion is an apartment building located at the northeast corner of 4 th and Main Streets. This location was the former site of the Westminster Hotel, the only historic building at this intersection to have been demolished. The Medallion includes 96 apartment units and 85,000 square feet of retail space. The current building represents Phase I of the project and was completed

in the summer of 2010. Phase II of the project has received entitlements but otherwise no new information regarding its development schedule is available at present. (Figure 6.12) (Guzman, 2010) 


\section{Bringing Back Broadway}

Bringing Back Broadway is a public-private partnership initiative whose overall goal is to preserve and enhance the Broadway Corridor's rich architectural and cultural heritage and reactivate its commercial and office functions and spaces. The partnership has a ten-year, 9-point plan for the revitalization and restoration of this nationally recognized historic district. (City of Los Angeles, Bringing Back Broadway, 2012)

Recent developments include the announcement that Ross Dress for Less, the headquarters of jewelry maker Tarina Tarantino, the 180-room boutique Ace Hotel, and the French restaurant Figaro Bistro will be locating in the district. A Broadway Sign District is also in the works to preserve and reactivate historic marquees and signs on the street's buildings. District City Councilman José Huizar's office is also working on a set of commercial reuse guidelines to activate the nearly 1 million square feet of vacant space above street level. (Guzman, Regardie, \& Vaillancourt, 2012)

\section{Spring Street Park}

Spring Street Park will occupy a currently vacant, L-shaped parcel on the east side of Spring Street between 5th and 6th Streets. (Figure 6.13) The $\$ 8$ million park will feature paths, a plaza, benches, a fountain, trees, and artwork. Construction began in October of 2011 and the park is scheduled to open in April 2013. (Guzman, Regardie, \& Vaillancourt, 2012)

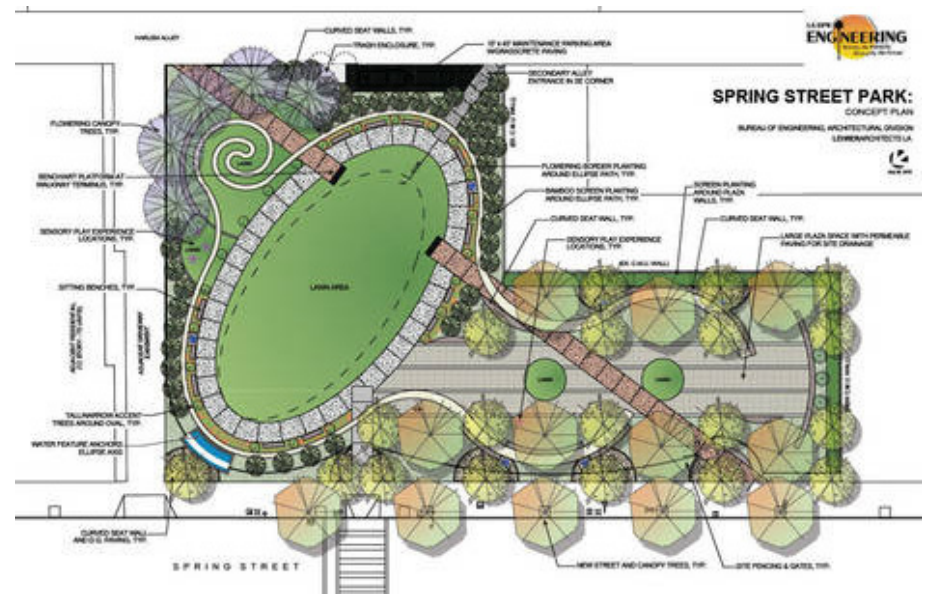

Figure 6.13. Spring Street Park (Lehrer Architects LA/ City of Los Angeles Bureau of Engineering) 
In 1999, the City passed an adaptive reuse ordinance that revised building codes and streamlined the entitlement process for the conversion of former Historic Core office buildings to residential use. Buildings near the Civic Center that have been converted under this ordinance include the Higgins Building, the Douglas Building, the Hosfield/Victor Clothing Building, and the PanAmerican Lofts.

Another, non-residential adaptive reuse project was the conversion of the Vibiana cathedral at 2nd and Main Streets into an event and performing art space. The cathedral, originally built in 1876, sustained heavy damage in the 1994 Northridge earthquake. The City took over ownership of the building from the archdiocese in 1996 and subsequently sold it to downtown developer Tom Gilmore in 1999 for $\$ 4.6$ million. The archdiocese built the new Cathedral of Our Lady of the Angels, which was dedicated in 2002. (Cathedral of Saint Vibiana, n.d.)

\section{Budokan}

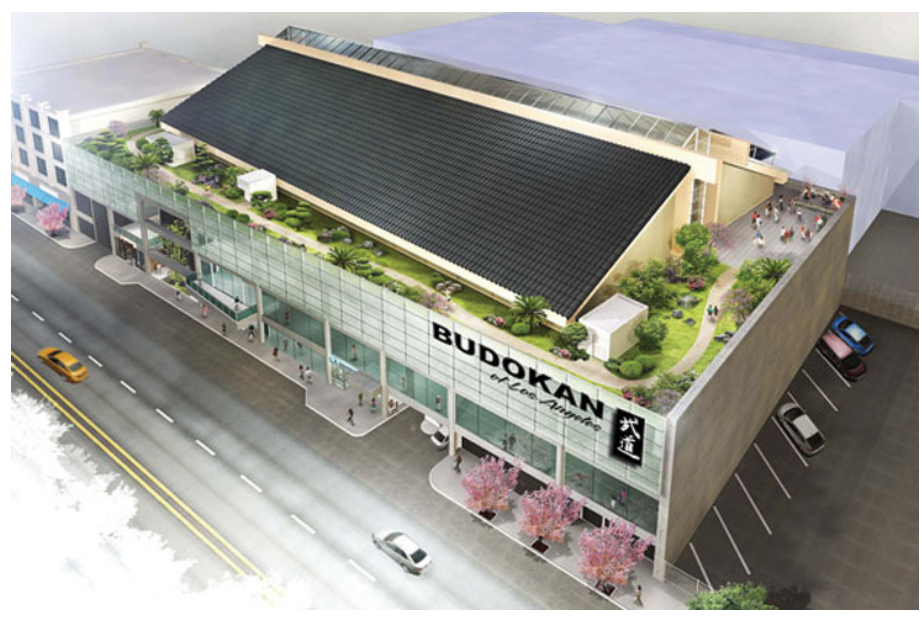

Figure 6.14. Budokan (Little Tokyo Service Center)
The Budokan of Los Angeles is a 38,000 square foot community center proposed by the Little Tokyo Service Center (LTSC). (Figure 6.14) The project was conceived in the 1970 s as way to make Little Tokyo more appealing to younger JapaneseAmerican residents while maintaining the area's historical cultural identity. The $\$ 22$ million project, which was approved by the City Council in May of 2011, will include a four-court gymnasium and a rooftop garden with jogging track. A capital campaign launched in August 2011 has so far secured $40 \%$ of the project's cost. (Budokan of Los Angeles, n.d.; Yen, April 3, 2012; Yen, May 18, 2011) 


\section{Conclusions}

The development reviewed in this chapter represents a range project types and sizes, from largescale redevelopment and transportation infrastructure to residential infill, historic preservation, and adaptive reuse. However, an evolving understanding of and respect for the existing urban fabric of Downtown Los Angeles informs all of these projects. The diversity of project sizes and types indicate that different areas of Downtown and the study area require different development approaches to achieve urban design goals of improved physical and historical connectivity and continuity. A remaining challenge is how to coordinate these strategies to ensure that all new development contributes to Downtown's cumulative identity and continuity. 
Chapter 7. Current Conditions: Regulatory Setting 


\section{Introduction}

Over the past decade, the City has enacted several policies and design guidelines intended to promote more context-sensitive development and to improve the overall quality of life within Downtown. The most significant of these policies has been the adaptive reuse ordinance adopted by the City in 1999. This ordinance eased parking requirements and streamlined the entitlement process for developers seeking to convert historic buildings to residential use. Since its adoption, dozens of historic structures have been converted to apartments and condominiums, including four buildings within the Development Study site. Other important policy developments include the creation of design guidelines for the Downtown, the Historic Core, and the Broadway Corridor; zoning changes to facilitate appropriate development around subway stations; and ordinances incentivizing housing development and allow the development of district-specific parking strategies.

\section{Development Study Site Location and Description}

The Development Study site examined in Chapter 9 is bounded by Main Street to the east, 3rd Street to the south, Hill Street to the west, and 2nd Street to the north. The site lies mostly within an area designated as Civic Center South in the city's Downtown Design Guide. (Figure 7.1) The site includes 64 parcels and encompasses approximately 13.4 acres. Developed properties generally contain either commercial or residential structures built prior to World War II or large parking structures. Undeveloped parcels are for the most part being used as parking lots. The land is subdivided into parcels similar in

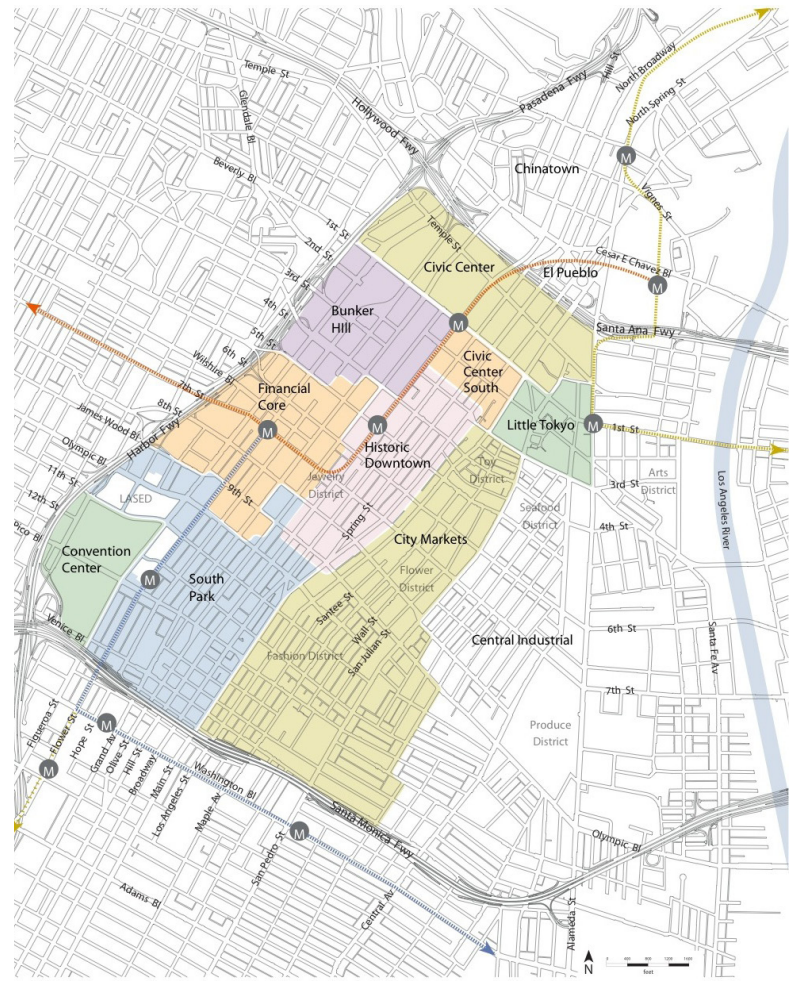

Figure 7.1. Map of districts subject to Downtown Los Angeles Design Guide policies. City of Los Angeles Department of City Planning, Downtown Design Guide (2009) 
size to those in the Historic Core to the south. However, several of these parcels are vacant and the site is located just south of the Civic Center, which is dominated by buildings occupying entire blocks.

\section{Downtown Specific Policies and Guidelines}

Downtown Strategic Plan (1993)

The area identified as Civic Center South in the Downtown Design Guide was previously included in the 1993 Los Angeles Downtown Strategic Plan as part of a larger district stretching past 4th Street and labeled Upper Center City. (Figure 7.2) The 1993 plan identifies a number of strategies for Upper Center City. Broadway and Spring Street are identified as the district's signature streets, with Main Street serving a primarily residential function and Hill Street providing a mixed-use transition to Bunker Hill. The plan calls for growth to be concentrated around the 4th and Hill Street Metro station. It also envisions a residential

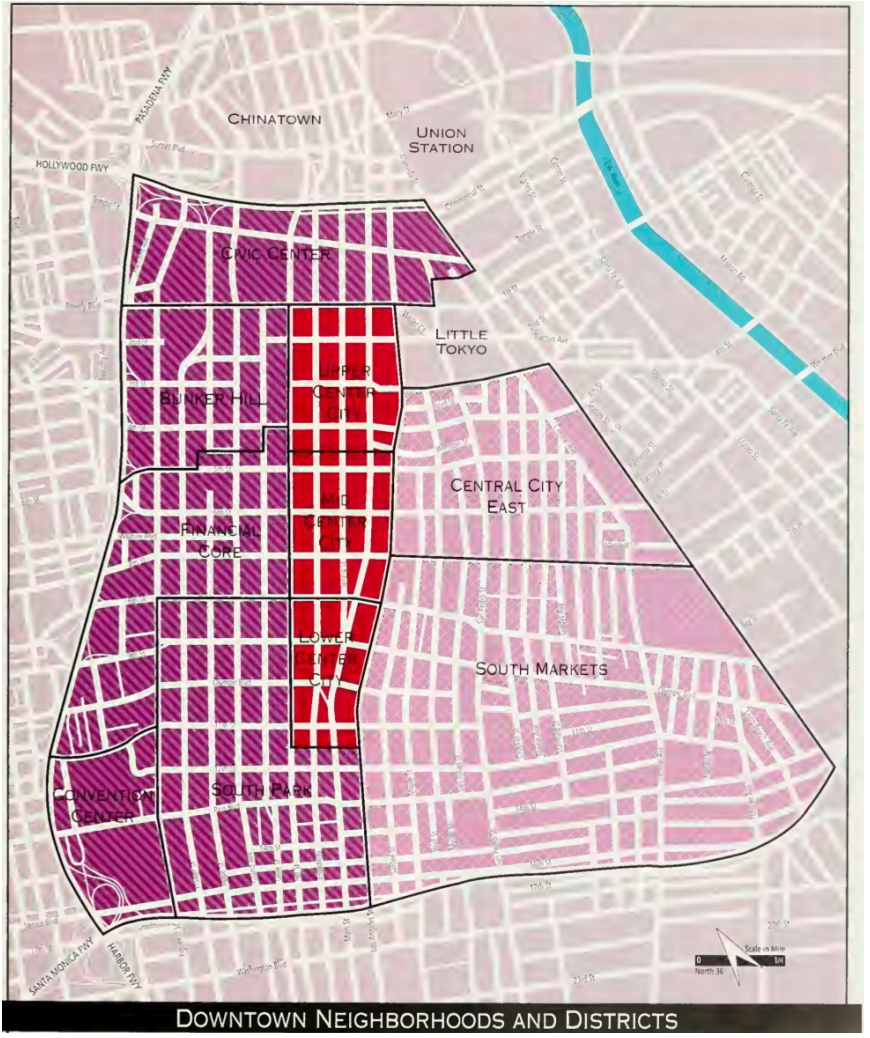

Figure 7.2. Map of Downtown Neighborhoods and District, 1993 Downtown Strategic Plan (City of Los Angeles, 1993) cluster with open space, retail, and community facilities adjacent to St. Vibiana Cathedral. And like the Downtown Design Guide, the 1993 plan also encourages the development of a network of mid-block paseos and gallerias throughout the area. (p. 48) 


\section{Downtown Design Guide}

The Downtown Design Guide (2009) provides both standards (requirements) and guidelines (suggestions) for development within Downtown. Specific highlights of the Guide that informed the urban design recommendations for the Opportunity Sites portion of this study. Chapter 3 of the Guide details the sidewalk and setback requirements for downtown. Within the site, Broadway, 2nd Street, and 3rd Street are designated as commercial streets where ground floor retail space is required along at least $75 \%$ of the street frontage. (City of Los Angeles Department of City Planning)

Chapter 5 details parking and access requirements. Specifically, the Guide requires that "no more than the minimum required parking may be provided unless provided for adjacent buildings that lack adequate parking" and that rental and for-sale parking must be unbundled from residential and commercial uses in perpetuity. It also recommends that unused residential and commercial parking be made available for public use during daytime and evenings. (City of Los Angeles Department of City Planning, 2009, p. 21) Chapter 5 also addresses uses of alleys, calling for preservation and enhancement of existing alleys and their functions. However, alleys are allowed to be vacated if " 1 ) vehicular access to the project is provided only at the former intersection of the alley with the street; 2) vacating the alley will not result in the need for additional curb cuts for other parcels on the same block; and 3) an east-west pedestrian paseo at least 20 feet wide will be provided in the middle third of the block as part of the project." (p. 24)

Chapter 6 details the massing and streetwall requirements for downtown. Generally, the Design Guide calls for a mostly uninterrupted 6-story streetwall along the streets within the area, with slightly higher percent of street frontage required for commercial streets. The Guide also calls for ground floor retail to be built up to the sidewalk and other uses to include setbacks at varying depths and intervals to create an interesting pedestrian environment. It is recommended that large projects be broken into a series of appropriately scaled buildings so that no building is more than 300 feet in length. (City of Los Angeles Department of City Planning, 2009, p. 26) 
Chapter 7 addresses open space. The Guide recommends that projects that have more than 300 feet of frontage or are located in the middle of the block provide mid-block pedestrian pathways or paseos when block length is 400 feet or longer. The Guide provides specific requirements for paseo designs and provides recommendations for corner plazas.

\section{Historical Downtown Design Guidelines}

Within the Development Study site, the Historical Downtown Design Guidelines apply only to the parcels along the north side of 3rd Street. (Figure 7.3) Chapter 4 of the Guidelines addresses new construction and how the design of new buildings should relate to the surrounding urban context:

In any district, common design

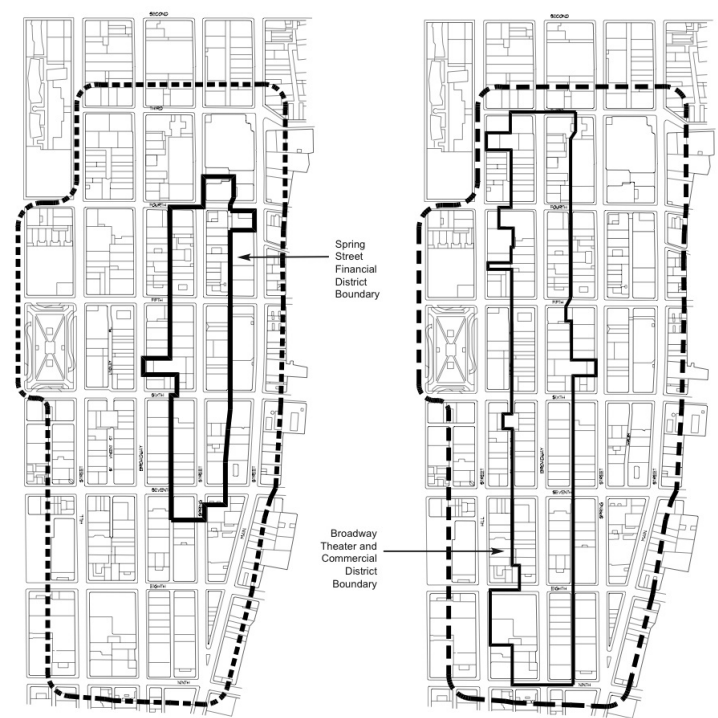
characteristics, such as building height and bulk, rhythm of openings, Figure 7.3. Historic Downtown Los Angeles Design Guidelines and materials, establish parameters for compatible infill construction. These parameters do not prescribe a slavish copying of historic features or creation of "historic looking" buildings. Although today's technologies provide the ability to create buildings that duplicate the appearance of older, historic buildings, this type of historicism is discouraged under The Standards and these design guidelines. New construction should both respect the authentic character of the existing building stock and place its own contemporary stamp on the urban setting. (Los Angeles Conservancy, 2002, p. 130)

Street Guidelines detailed in Chapter 5 specifically identify the role and benefits of pedestrian pathways within the Historic Core:

Threading a series of pathways throughout the Historic Downtown core area can draw and link activities from one sub-area to another... A path of connections, including a network of mid-block pathways, enhanced alleyways, and green spaces, together 
could provide enjoyable

links between major

thoroughfares... One of the

more important benefits of

this kind of feature is that

the paths effectively reduce

the size of the blocks in

downtown. [Figure 7.4] (p.

147)

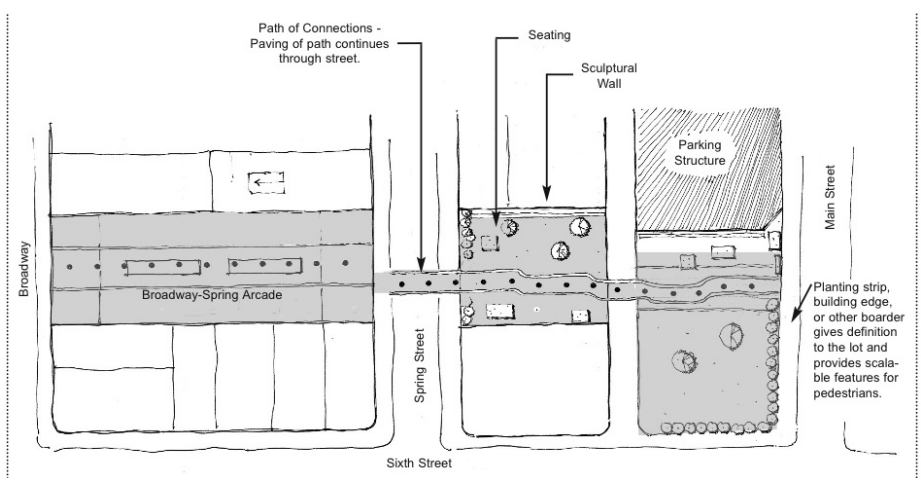

Figure 7.4. Mid-block pedestrian pathway treatment, Historic Downtown Design Guidelines. (Los Angeles Conservancy 2002, p. 148)

Broadway Theater and Entertainment District Design Guide

All parcels along Broadway and some parcels along Spring Street are also subject to guidelines contained in the Broadway Theater and Entertainment District Design Guide. (Figure 7.5) These guidelines are generally intended to restore and enhance the distinct character of the Broadway corridor. (City of Los Angeles Department of City Planning, 2009)

Guideline 1 for new construction states that new development should "[p]ursue creative and innovative contemporary designs for new buildings that will complement Broadway's designated National Register Historic District." Standard 1b of this guideline recommends that "[d]evelopment of large sites should respect the traditional lot patterns, vertical rhythms, horizontal building forms as well as maintain the tradition of articulated, transparent storefronts and storefront entryways and prominent main building entries on the ground floor facing a public street." ( $p$.

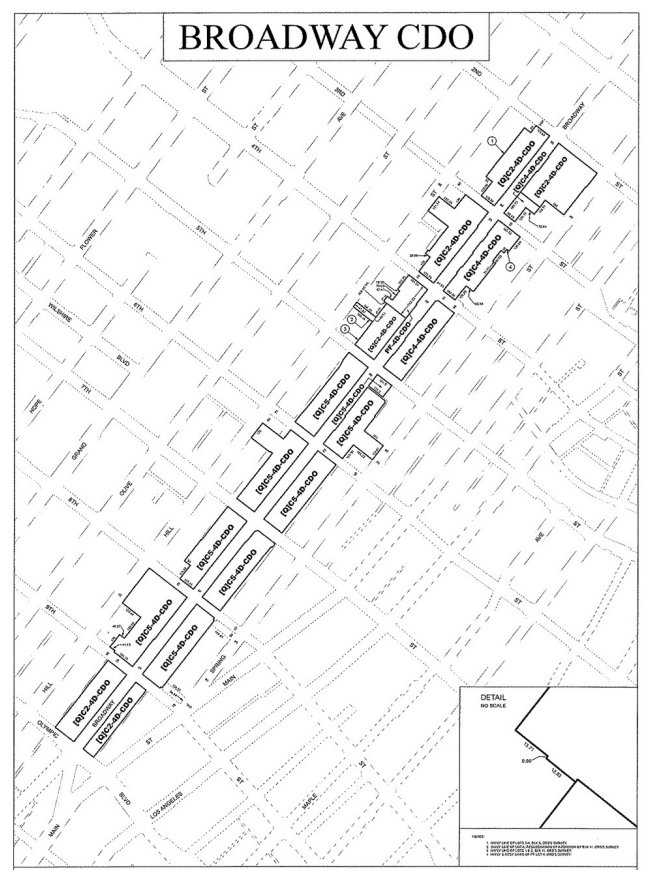

Figure 7.5. Broadway Theater and Entertainment Design subject area. (City of Los Angeles Department of City Planning, ZI No. 2408, 2009) 
Downtown Adaptive Reuse Incentive Area

In 1999, the City of Los Angeles adopted regulations to encourage the conversion of existing buildings to new residential uses. According to the City's updated handbook for the program:

The City's Adaptive Reuse Program works by streamlining the process developers must follow to get their projects approved, resulting in substantial time saving. The Program's first component, a set of land use ordinances, relaxes parking, density, and other typical zoning requirements. Through fire and life safety measures, the Program's second component provides flexibility in the approval and permitting process. (City of Los Angeles Mayor's Office of Housing and Economic Development, 2006)

\section{Modified Parking Requirement (MPR) District}

In September 2011, the City of Los Angeles Planning and Land Use Management committee approved the Modified Parking Requirement District ordinance. This ordinance allows parking districts throughout the city to tailor their own parking strategy using one of seven parking requirement modification tools. The seven tools include (1) change of use parking standards, (2) use of a new Parking Reduction Permit, (3) off-site parking within 1500 feet, (4) decreased parking requirements, (5) increased parking requirements, (6) commercial parking credits, and (7) maximum parking limits. (Brasuell, 2011)

\section{Zoning and Permitting}

\section{Land Use and Zoning}

According to Zimas and the General Land Use Map for the Center City Community Plan, all parcels within the site are designated "Regional Center Commercial." The General Land Use Map also indicates that these parcels are allowed a maximum floor-area ratio (FAR) of 6:1. However, the Los Angeles Municipal Code and the CRA Redevelopment Plan permit a Transfer of Floor Area allowing for a maximum FAR of 13:1, corresponding with the 4D Height district. (Figure 7.6) (City of Los Angeles Department of City Planning, Center City Community Plan General Land Use Map, 2009) 

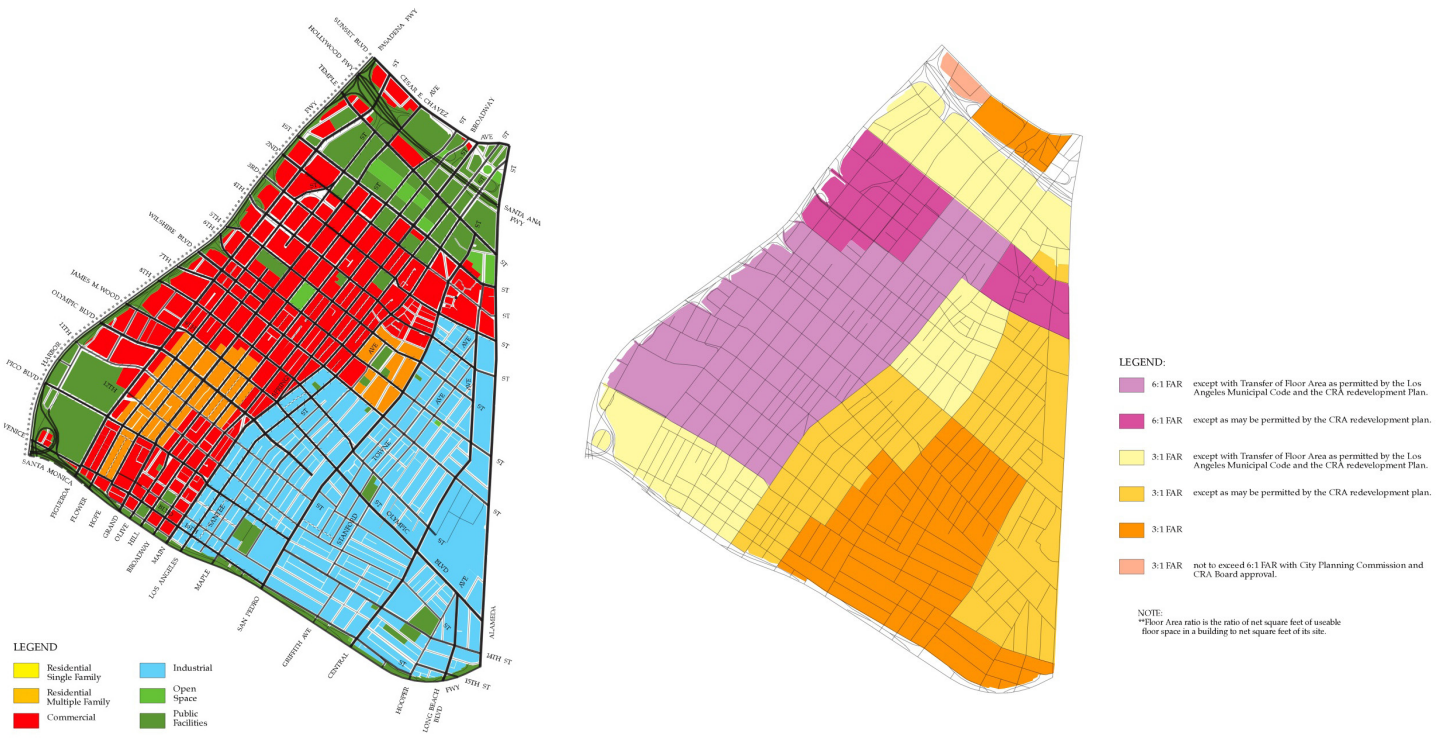

Figure 7.6. Generalized Land Use Map (left) and Floor Area Ratio Map (right), Center City Community Plan General Land Use Map (City of Los Angeles Department of City Planning, 2009)

All parcels within the site are zoned for either $\mathrm{C} 2$ or $\mathrm{C} 4$ commercial use. The $\mathrm{C} 2$ designation is the broadest and most inclusive of all the City's retail commercial zones. The C4 zone is largely the same as the C2 zone, but has greater restrictions on permissible uses. (City of Los Angeles, 2012) All parcels along Broadway as well as parcels along Spring Street included as part of the Times parking garage are part of the Broadway Community Design Overlay district, as indicated by the CDO suffix. (Figure 7.7) (City of Los Angeles Department of City Planning, 2012)

Several parcels within the site carry a Permanent [Q] Qualified Conditions zoning classification. This classification is intended to ensure compliance with and implementation of essential components of the Downtown Design Guide and the Broadway Theater District Design Guide. According to the Broadway Design Guide (2009), "Those standards required by the [Q] Conditions will create an inviting pedestrian environment to support the Broadway Theater District. The standards,

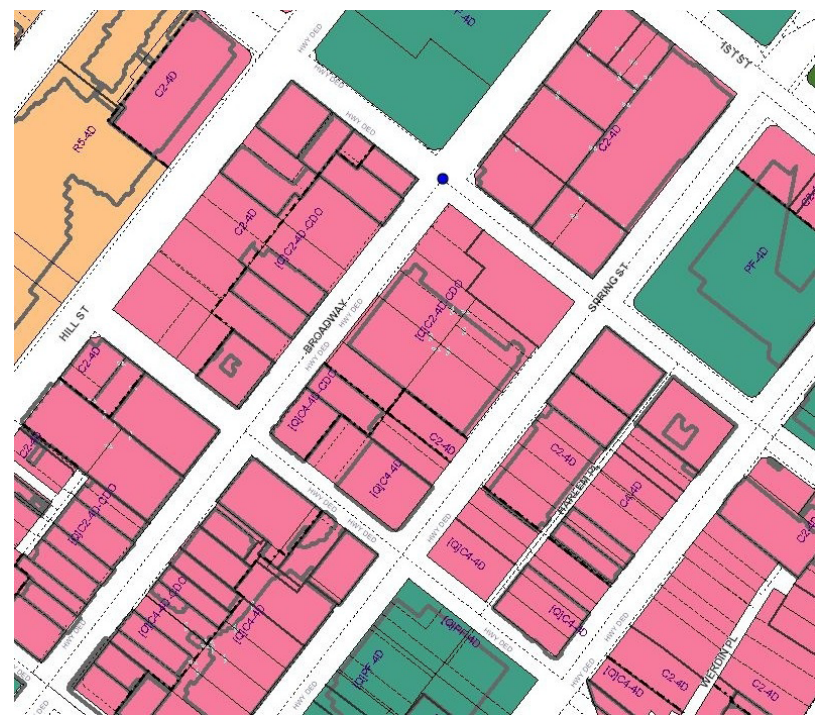

Figure 7.7. Generalized Zoning within the site. (City of Los Angeles Department of City Planning, 2012) 
for example, will require that all buildings be built to the property line; parking be located to the rear of buildings or underground, as feasible; ground floors maintain transparency and contain active uses; and new construction complement the scale and massing of the District's existing historic fabric." (City of Los Angeles Department of City Planning, p. 8) Plans proposed for these parcels will be submitted for review and approval by the Director of Planning for compliance with all limitations, standards, and specific qualifications that apply to the parcel. (City of Los Angeles, Municipal Code, 2012)

\section{Metro Rail Project Area}

Certain construction activities on parcels located along Hill Street and above the subway tunnel for Metro Red and Purple lines require review by the MTA. Construction activities that are subject to review include: delivery of materials, erection of exterior sign scaffolding, installation of refuse tubes or similar items, demolition, borings, tunneling, seismic retrofitting and excavations, new structures, and additions to existing structures. Projects that do not require MTA clearance include tenant improvement projects, changes of use, and use of lands which involve no construction activities. (City of Los Angeles Department of City Planning, 2012)

\section{Redevelopment, Revitalization, and Business Improvement}

\section{City Center Redevelopment Project}

The Development Study site study falls within the City Center Redevelopment Project Area of the City of Los Angeles Community Redevelopment Authority. (Figure 7.8) (Community Redevelopment Agency of the City of Los Angeles, 2002) However, due to the recent dissolution of California's redevelopment agencies, the City has taken several measures to transfer jurisdiction of the CRA's responsibilities and authority to the City's Planning Department. City Planning Commission case number CPC-2010-213-CA (2010) amended several

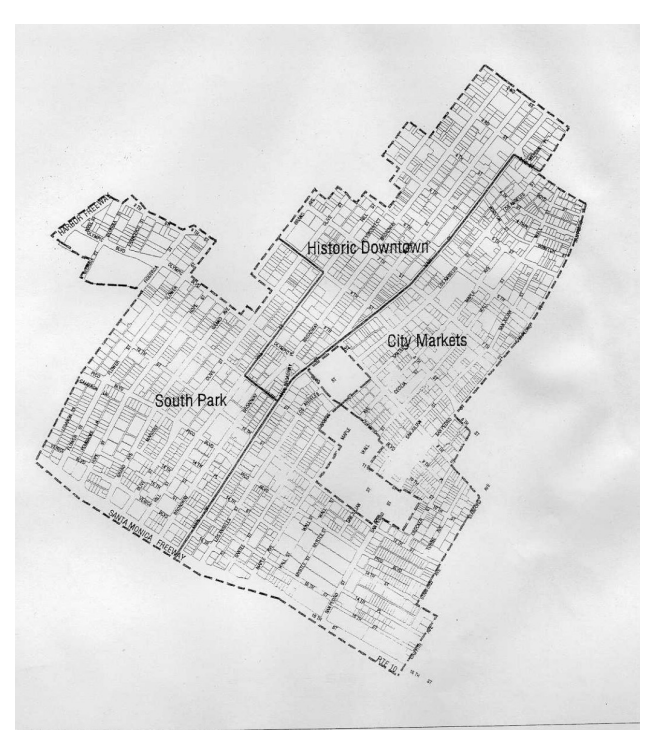

Figure 7.8. CRA/LA City Center Redevelopment Project Map. (Community Redevelopment Agency $\mathrm{s}^{\text {of the City of Los Angeles, 2002) }}$ 
of the Los Angeles Administrative Code to transfer jurisdiction for administering Transfer of Floor Area Rights (TFAR) from the CRA to the Department of City Planning. (City of Los Angeles Department of City Planning, 2010)

Downtown Center Business Improvement District

The project site lies within the Downtown Center BID. (Figure 7.9) This coalition of downtown property owners performs a number of duties aimed generally at promoting Downtown interests and enhancing the quality of life there. Activities performed by the BID include the funding of a 24 -hour "Purple Patrol" that monitors the Downtown Center and Historic Core and the provision of economic development and marketing

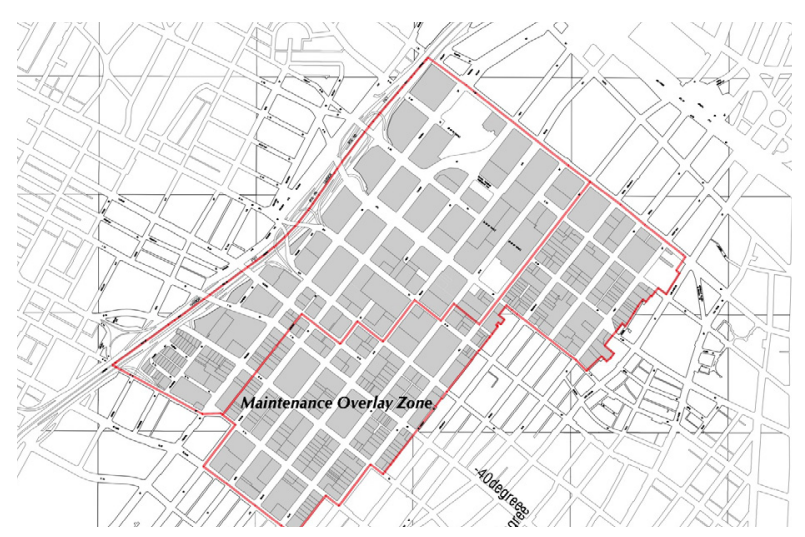

Figure 7.9. Downtown Center BID Map. (Downtown Los Angeles Center Business Improvement District, 2012) services. (Downtown Los Angeles Center Business Improvement District, 2012)

\section{Los Angeles State Enterprise Zone}

The study area is part of a State Enterprise Zone, as designated by a City Council resolution and approved by the California Department of Commerce. This designation makes available tax and regulation relief and improvements to public services to stimulate local investment and employment. This specific Enterprise Zone allows for reduced parking ratios for a number of uses and establishes special height districts elsewhere in the zone. (City of Los Angeles Department of City Planning, ZI No. 2374, 2010)

\section{Los Angeles Climate Action Plan}

In May 2007, the City of Los Angeles adopted its Climate Action Plan, titled "GreenLA: An Action Plan to Lead the Nation in Fighting Global Warming." The plan states the City's goal to reduce greenhouse gas emissions to $35 \%$ below 1990 levels by 2030. For the Land Use focus area of the plan, the City identifies the creation of a more livable city as its goal. The plan lists a series of 
land use strategies for achieving livability and GHG emission reduction goals, including: making underutilized city land available for housing, mixed-use development, parks, and open space; cleaning up brownfield sites for community economic revitalization projects and open space; and making underutilized city land within 1,500 feet of transit for available for housing and mixed-use development. (pp. 22-3)

\section{Conclusion}

Over the past two decades, the City has enacted several land use and development policies that have been effective in revitalizing Downtown and protecting its historic fabric, particularly within the Historic Core. However, challenges remain in the effort to establish a coherent vision for the north end of Downtown and create an appropriate and effective policy framework to implement

that vision. The Project Restore master plans and the Park 101 project discussed in the previous chapter have both advanced compelling visions for this area of Downtown. These proposals could potentially inform future land use policies and design guidelines. 
Chapter 8. Opportunity Sites 


\section{Introduction}

Understanding the historic context of the study area can help guide new development and urban design and help shape reparative development strategies while also meeting the demands of current land use policies, economic imperatives, and urban design standards. Specifically, the historic development context can help in establishing urban design goals and in identifying specific opportunity sites to implement those urban design goals. The opportunity sites presented here were determined based upon their capacity for new development or redevelopment, their strategic locations within Downtown, and their potential to restore physical and historical continuity in the built environment. (Figure 8.1) Urban design within these sites can be utilized to reconcile discontinuities of scale, diversify land uses, and create a contemporary identity that is nonetheless informed by sitespecific history.

\section{Site 1: Los Angeles Street and Main Street}

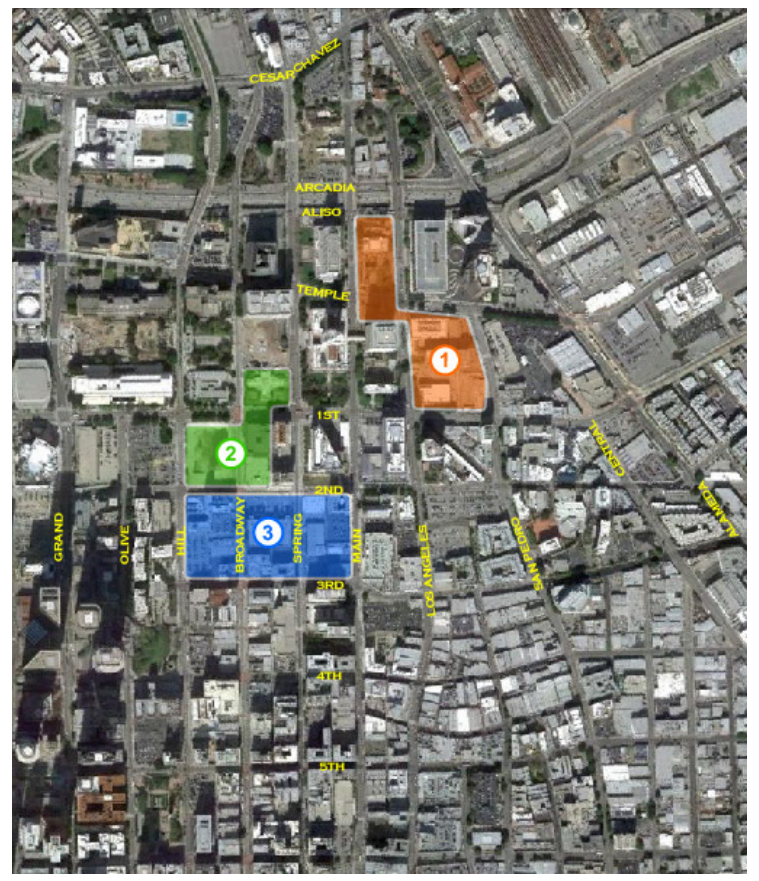

Figure 8.1. Opportunity Sites: (1) Los Angeles Street and Main Street, (2) Broadway and 1st Street, and (3) Civic Center South

Urban Design Goals

The Civic Crossroads Plan identifies Main and Spring Streets as the primary linkage streets between El Pueblo, the Civic Center, and the Historic Core, with Los Angeles Street and Broadway providing secondary linkage roles. The plan also calls for Main and Spring Streets to be designed with their unique histories and characteristics in mind. (Project Restore, 2006, p. 35) Because Los Angeles Street and Main Street developed in tandem as Downtown expanded southward, redevelopment along these corridors should focus on restoring the historical physical links between El Pueblo and the rest of Downtown that were erased by redevelopment. To improve connectivity and continuity along these corridors, the street walls should be strengthened and more street activity should be encouraged. Opportunities to restore connections to this area's rich past and accentuate remaining historical traces should be strongly encouraged. 
A coordinated strategy of infill development for the Los Angeles Mall and the Parker Center sites could potentially extend the benefits of the proposed Park 101 project southwards, amplifying its transformative potential and bolstering its possible adoption and implementation. To reduce the gap in active streets along Main Street, Los Angeles Street, and 1st Street, the design of new infill development should employ: urban scale street wall massing; façade articulation and detail; street level building entrances and street front windows and doors; distinctive materials; and decorative details. (Downtown Design Guide, 2009, Ch. 4, p. 19) Changes in zoning and land use regulations should be explored to diversify the mix of land uses to the area, complement the proposed park plans, and promote non-work hour commercial activity and street life.

\section{Site 2: Broadway \& 1st Street}

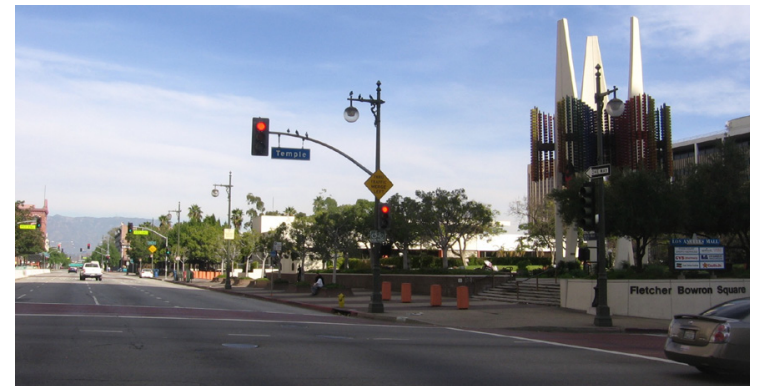

Figure 8.2. East side of Main Street looking north from Temple Street

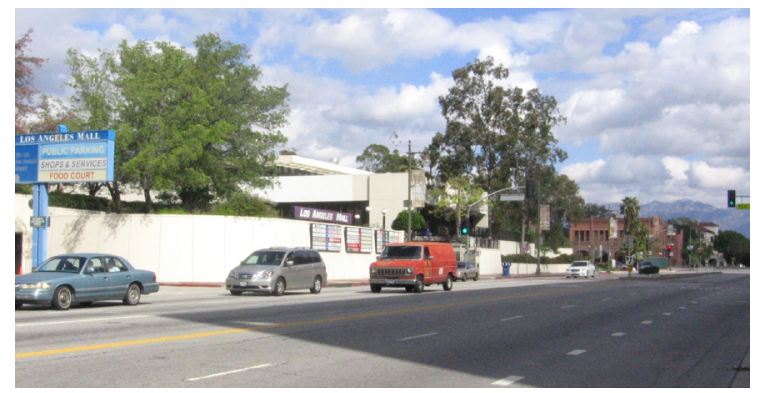

Figure 8.3. West side of Los Angeles Street looking north from Temple Street

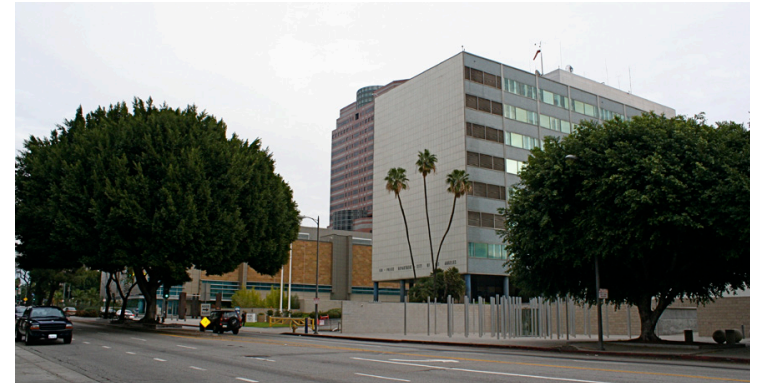

Figure 8.4. East side of Los Angeles Street between Temple and 1st Streets showing the entrance to the Parker Center

\section{Urban Design Goals}

Prior to redevelopment, this intersection was a transition point between the central business district and points to the north and west. However, the pre-war widening of 1st Street removed all the original buildings on the north side of this intersection while the postwar redevelopment removed all the original buildings except for the Times Building on the south side. Today, this intersection lacks a sense of place due to vacant parcels on the southwest and northeast corners (Figures 8.5 and 8.6), the short massing and deep setbacks of the LA Law Library (Figure 8.7), and the heavy massing, dark colors, and blank facades of the Los Angeles Times West Building 
and Executive Parking Structure (Figure 8.8). Nonetheless, this remains an important transitional intersection within today's Downtown. Infill development and redevelopment should be employed to restore and strengthen place identity to these areas, paying particular attention to massing, the street wall, and ground floor details, as well as the surrounding and historical context.

\section{Opportunity Sites}

The transitional functions of this intersection are particularly important in the context of Downtown redevelopment since the 1960s. Redevelopment has resulted in significant upheaval in the area's urban form and functions, including:

- Replacement of former residential functions at the northern end of Bunker Hill with governmental and cultural functions

- Proposed development of the Grand Avenue Project, which will bring additional residential, hotel, and commercial functions to the area

- Anticipated construction of the new Federal Courthouse on the currently vacant southwest corner.

- Construction of the Metro subway station for the Red and Purple lines at Hill and 1st Streets

- Proposed construction of a new Regional Connector Station at Broadway and 2nd Street

- Proposed linking of City Hall Park and the LAPD Headquarters plaza across 1st Street

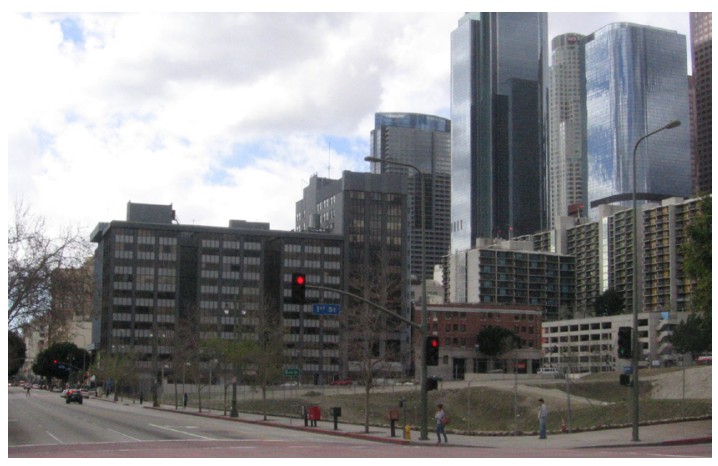

Figure 8.5. Future site of the new Federal Courthouse, southwest corner of Broadway and 1st Street

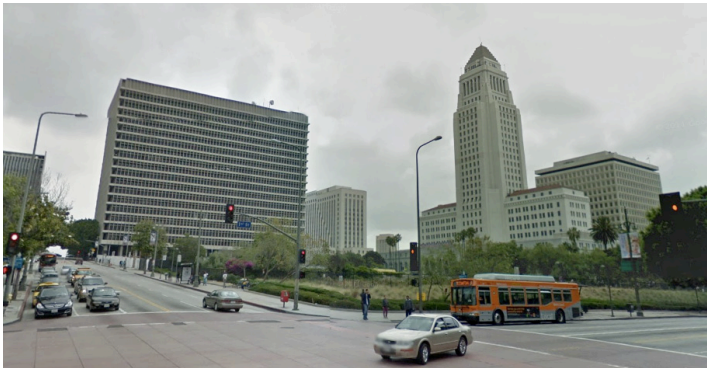

Figure 8.6. Former site of the 1933 California State Office Building, northeast corner of Broadway and 1st Street

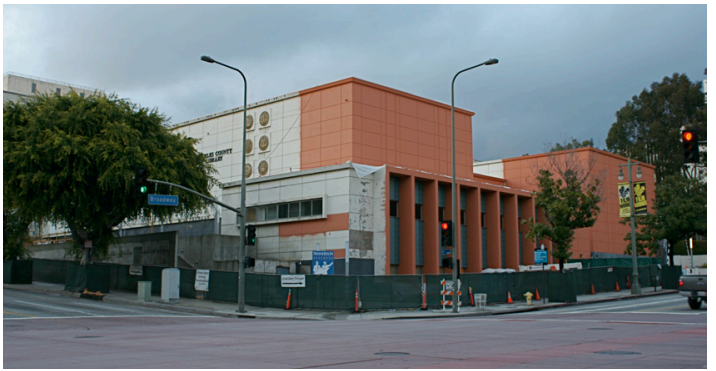

Figure 8.7. Los Angeles County Law Library, northwest corner of Broadway and 1st Street

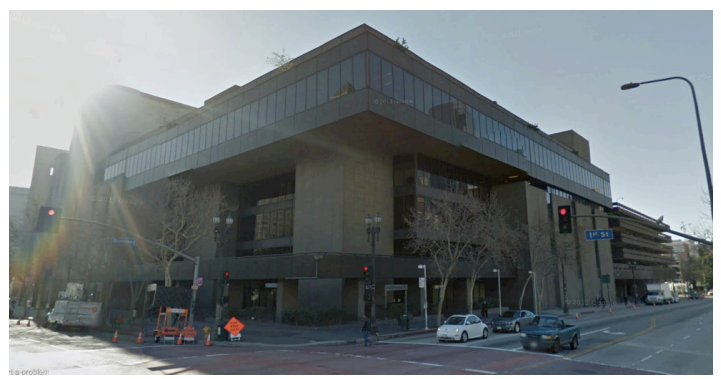

Figure 8.8. Los Angeles Times West Building, southeast corner of Broadway and 1st Street 
New development and urban design should be informed by this surrounding context as well as the area's topography, transit accessibility, and transitional location between Downtown districts. The Times West Building could potentially be remodeled to mitigate its dark colors and heavy massing and to provide more façade details and greater horizontal variation along the street wall. Alternately, the building could be redeveloped along with the parking structure to restore a more diverse mix of land uses to this part of town. Development of the 1933 California State Office Building site could fill the gap along the north side of 1st Street and restore definition and identity to this corner.

\section{Site 3: Civic Center South}

\section{Urban Design Goals}

The Civic Center South site offers unique opportunities for restoring the urban fabric between the Civic Center and the Historic Core. The land encompassed within the site is subdivided into numerous narrow parcels similar to those of the Historic Core. The site is also located just south of the Civic Center, which is dominated by buildings that occupy entire blocks. Over the course of redevelopment, the site has experienced spillover from and the spatial "creep" of Civic Center development. As a result of these factors, a tension exists within the area between the existing fine-grained lot sizes, the opportunity for parcel assembly and large-scale development, and the imperatives of economies of scale. Construction of the Regional Connector will only increase development pressure on this site and intensify this tension.

Future development should address these tensions while also meeting current policy, economic, and urban design goals. To achieve these multiple objectives, an overall development vision and strategy should be created for the Civic Center South site. New development should build upon the site's historic character and unique position in relation to the Historic Core and the Civic Center, serving as a catalyst for revitalization within the larger study area and beyond. New development should also be coordinated with the Project Restore plans, the Park 101 project, the Grand Avenue Project, and the proposed Regional Connector station. 
Land within the Civic Center South area is currently underutilized, with much of it being used for surface parking. Most of the historic built environment has been removed or has severely deteriorated. However, the area contains numerous remaining historic and other assets, including four adaptively reused historic office buildings, dozens of local businesses, and a surprising continuity of street and district character. And although many of the early redevelopment projects in or near the areas were monotonous in design and monolithic in scale, recent development like the new LAPD Headquarters and the Caltrans District 7 building have been more attractive and context-sensitive in their design.

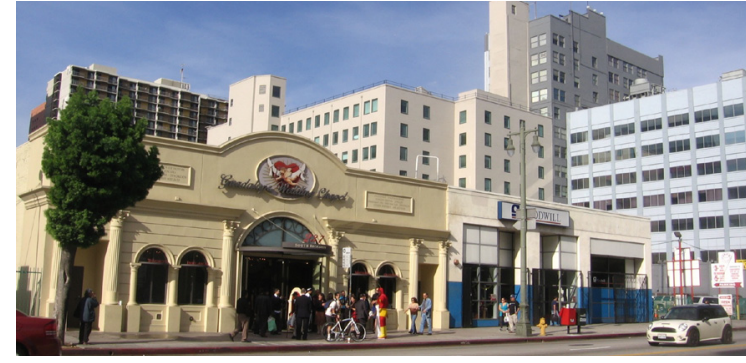

Figure 8.9. West side of Broadway between $2 n d$ and $3 r d$ Streets

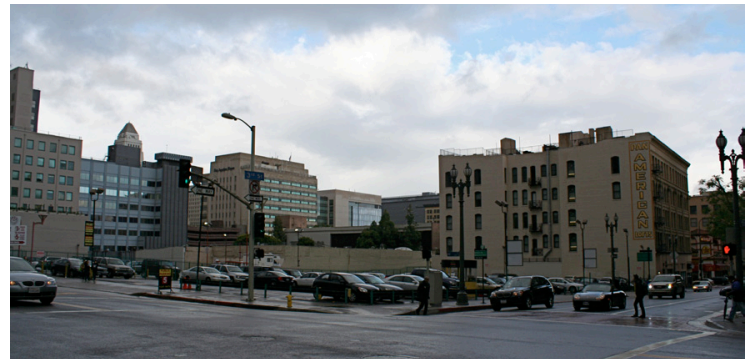

Figure 8.10. Northeast corner of Hill and 3rd Streets

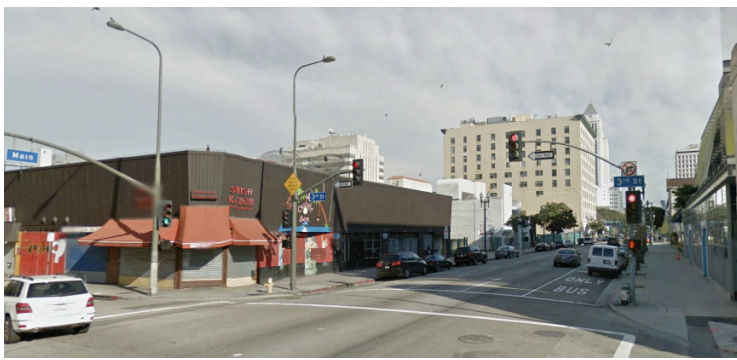

Figure 8.11. West side of Main Street looking north from 3rd Street

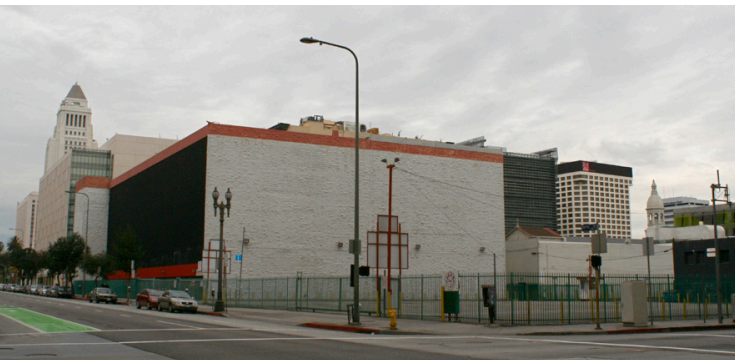

Figure 8.12. East side of Spring Street looking north from 3rd Street 
Chapter 9. Development Study 


\section{Introduction}

The following Development Study is intended to demonstrate how development and design within the Civic Center South opportunity site can be informed by historical development context of the area while also reflecting policies, urban design standards, and economies of scale as they apply to the site. The development and urban design proposals presented here aim to achieve the following four objectives:

- Create a unified identity for the Civic Center South district while respecting the identity of its component street corridors

- Establish the district's role as a transitional gateway between the Historic Core to the south and the Civic Center to the north

- Articulate the district's crosstown connections and its relationship with the adjacent districts of Little Tokyo and Bunker Hill

- Create a network of pedestrian pathways that facilitate circulation within the district and provide appropriate links to the larger Downtown circulation network

To achieve these goals, the study consists of three components (Figure 9.1): an office component clustered around the proposed 2nd Street Station and Plaza, a mixed-use component organized around a paseo between Broadway and Hill Streets, and a residential component along Main
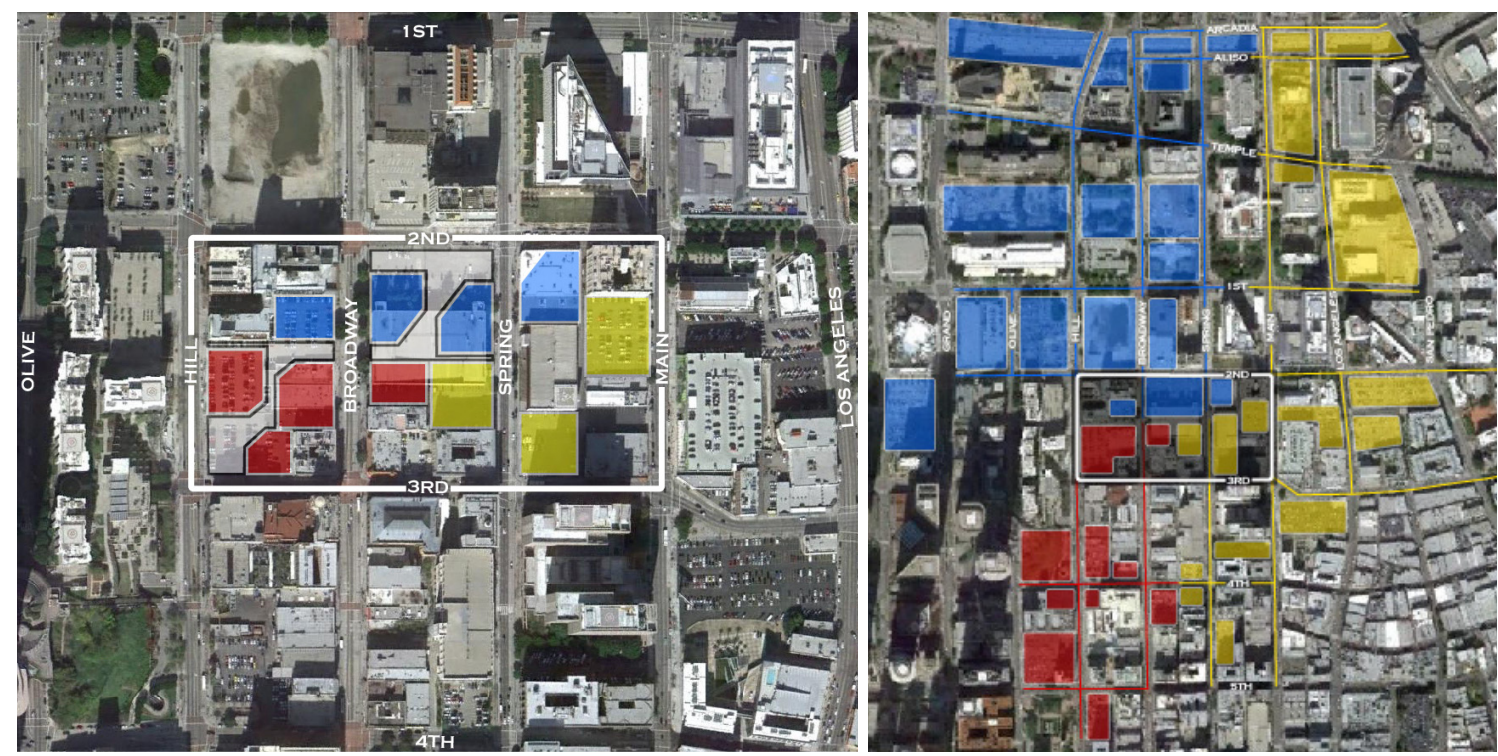

Figure 9.1. Civic Center South land use schematic

Figure 9.2. Proposed and available development sites around Civic Center South 
and Spring Streets. Each of these components is described in greater detail below. Three case studies are included to illustrate relevant design concepts and to demonstrate the feasibility of the proposed development types in comparable settings. Collectively, these three components contribute to four pedestrian corridors that are also described in this chapter. The study also examines the larger urban context of the area, including the district's relation to surrounding districts and how development can potentially strengthen overall connectivity within Downtown. (Figure 9.2)

\section{Component 1: Office/Subway Portal}

\section{Design Description}

The completion of the Regional Connector will make Civic Center South an important gateway within the Downtown, and the office/subway portal component has the potential to be the centerpiece of the redeveloped Civic Center South district. (Figure 9.3) The office/subway portal component could also become a key segment in a network of Downtown pedestrian corridors and open spaces, anchoring the eastern end of the 2nd Street residential and shopping corridor envisioned in the First Street Now! Plan. (Project Restore, 2005, Ch. i). (Figure 9.4)
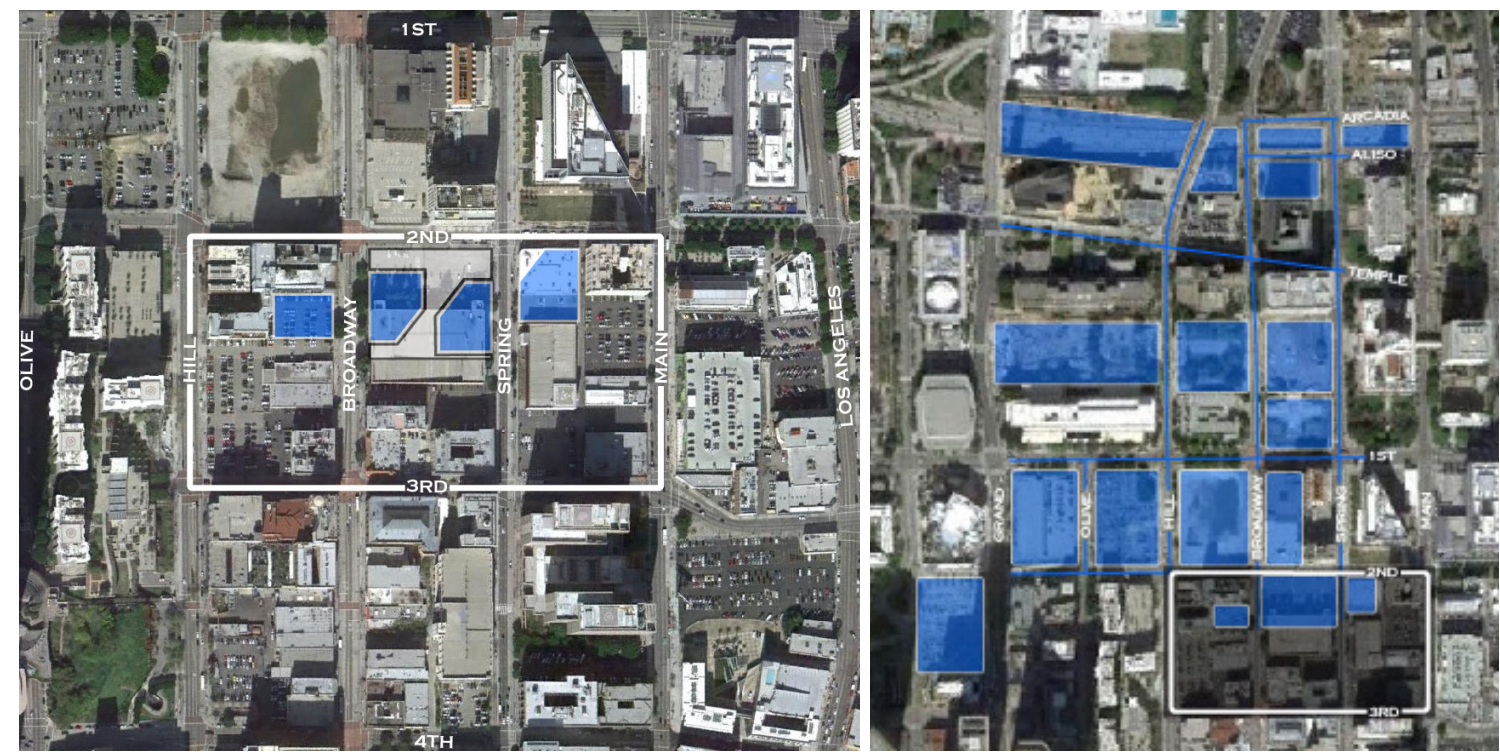

Figure 9.3. Office/Subway Portal Component land use schematic

Figure 9.4. Proposed and available development sites near the Office/Subway Portal Component 
Development above the new subway station at 2 nd \& Broadway also offers an opportunity to restore office functions to this area of Downtown and fill gaps in the built environment between historic assets such as the Times Mirror Building, the Higgins Building, the Douglas Building, and the LA Law Center. The design of these new buildings should remain contemporary and communicate the site's role as a gateway and transition area between the Civic Center and the Historic Core. The massing and arrangement of open spaces can also contribute to the transition between the dense Historic Core and the more spacious and monumental Civic Center.

In keeping with both the Civic Crossroads Plan and the 1993 Downtown Strategic Plan, new construction at the intersections of Spring and 2nd Streets and Broadway and 2nd Street should incorporate landmark features to signify the transition between districts. New development at Broadway and 2nd Street in particular should demarcate the northern end of the Broadway Corridor and complement the new Federal Courthouse. At southeast corner of Spring and 2nd Streets, redevelopment of the Wilcox Block should address not only the north-south transition, but also the east-west transition along 2 nd Street between the new plaza and the LAPD Headquarters Park. The massing of this site should also mesh with the surrounding area, providing a visual terminus for the eastern end of 2nd Street Station Plaza while maintaining the LAPD park's access to light and views of the Bunker Hill skyline.

Relevant Case Study: 1000 Connecticut Avenue, Washington, DC

\section{$\underline{\text { Summary }}$}

The 1000 Connecticut Avenue development provides an example of an appropriately scaled, premium office building located on a major regional rail transit line in the heart of a major city. (Figure 9.5) The design of the project

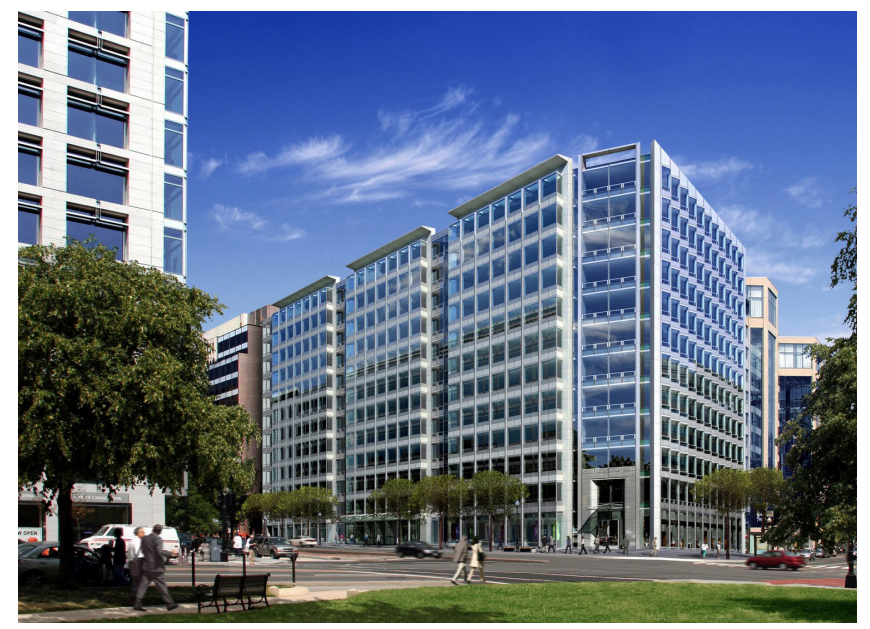

Figure 9.5. 1000 Connecticut Avenue rendering (Vornado/Charles E. Smith, n.d.) 
reflects its surrounding institutional context while presenting a contemporary aesthetic. The development also demonstrates how an iconic landmark can be created on a prominent and easily accessible parcel.

\section{Project Description}

1000 Connecticut Avenue is a Class A office building located at the prominent northwest corner of Connecticut Avenue and K Street in the "Golden Triangle" of Washington's central business district. The property was developed by Connecticut \& K Associates, LLC, designed by Pei Cobb Freed \& Partners, and contains 370,545 rentable square feet of office space and 15,246 rentable square feet of retail space. The building was completed in 2012 and is now home to the offices of Arent Fox LLP, a D.C. law firm. The property is located catty-corner to Farragut Square and is served by the Washington Metro Station of the same name. (Vornado/Charles E. Smith, n.d.)

\section{Relevance to this Study}

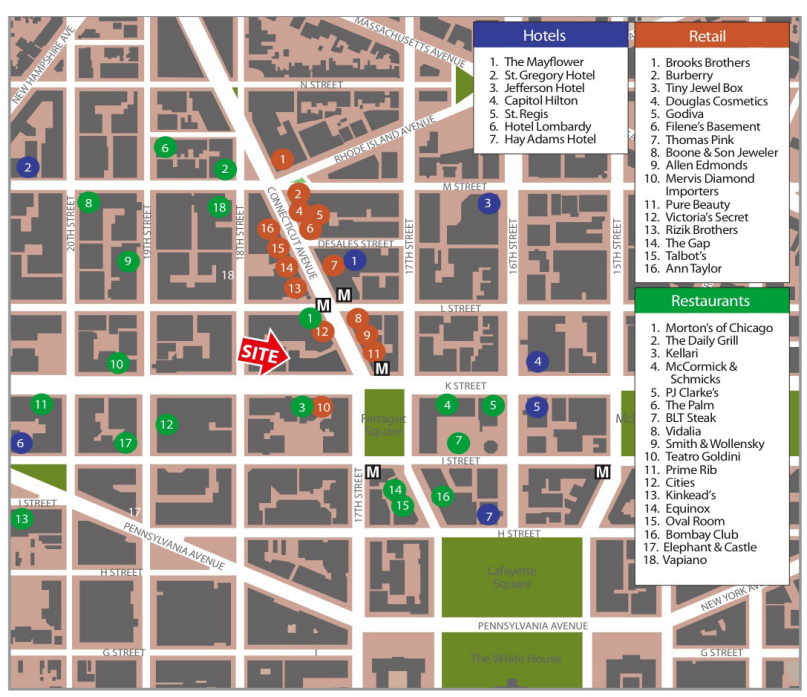

Figure 9.6. 1000 Connecticut Avenue destinations map (Rappaport Retail Brokerage, n.d)
The building and its location bear many similarities to the office/subway portal component proposed in this development study. K Street is a major east-west axis through Washington, DC, and is internationally renowned as the center of the city's law firms and lobbying industry. Connecticut Avenue is a major diagonal thoroughfare running through the city's Northwestern quadrant. (Figure 9.6) The Golden Triangle is situated between Washington's monumental and governmental core and historic urban neighborhoods such as Dupont Circle and Foggy Bottom. The Golden Triangle resembles the office/subway portal component in its commercial office function and its location between governmental and residential urban functions. 
Building heights in Washington are limited by the Heights of Buildings Act of 1910, which set height limits as equal to the width of the facing street, plus 20 feet. (Heights of Buildings Act of 1910 , n.d.) At 12 stories, 1000 Connecticut Avenue is comparable in height to the pre-1960 buildings of Los Angeles' Historic Core. And like the office/subway portal component, the building is also located within close proximity to a subway station and a large park.

\section{$\underline{\text { Design Features }}$}

The design of 1000 Connecticut Avenue optimizes the site's prominence, visibility, and convenient location. The architects used both traditional and modern materials to create a landmark that reflected the surrounding historic and institutional context while remaining thoroughly contemporary. The design also highlights the dramatic views of $\mathrm{K}$ Street, Farragut Square, and the White House from its upper floors and its rooftop terrace. (Vornado/Charles E. Smith, n.d.)

\section{Component 2: Mixed-Use}

\section{Design Description}

The mixed-use component of the study occupies the southern portion of the block bounded by Broadway and Hill, 2nd, and 3rd Streets. (Figure 9.7) The component includes commercial frontage along Broadway that flows into the site via a pedestrian paseo, opening into a plaza at the corner of Hill and 3rd Streets. The plaza is conceived as quiet, park-like retreat from the bustle of Broadway. It would also complement the assets located along this section of Hill Street, such as the Angelus Plaza senior apartment complex and the Hill Street entrance of Central Market. Between Broadway and Hill Street, the grade of the site rises roughly five feet. This topographical feature could be incorporated into the site plan to heighten the sense of transition between the two streets.

Infill development along the Broadway side of the site would adhere to the guidelines of the Downtown Design Guide, particularly those relating to massing and street wall requirements. New development should mesh with the cluster of landmarks to the south, including the Million Dollar Theater, the Bradbury Building, and the Central Market. Hill Street also contains several notable landmarks and destinations, including Central Market and the Angels Flight funicular. 

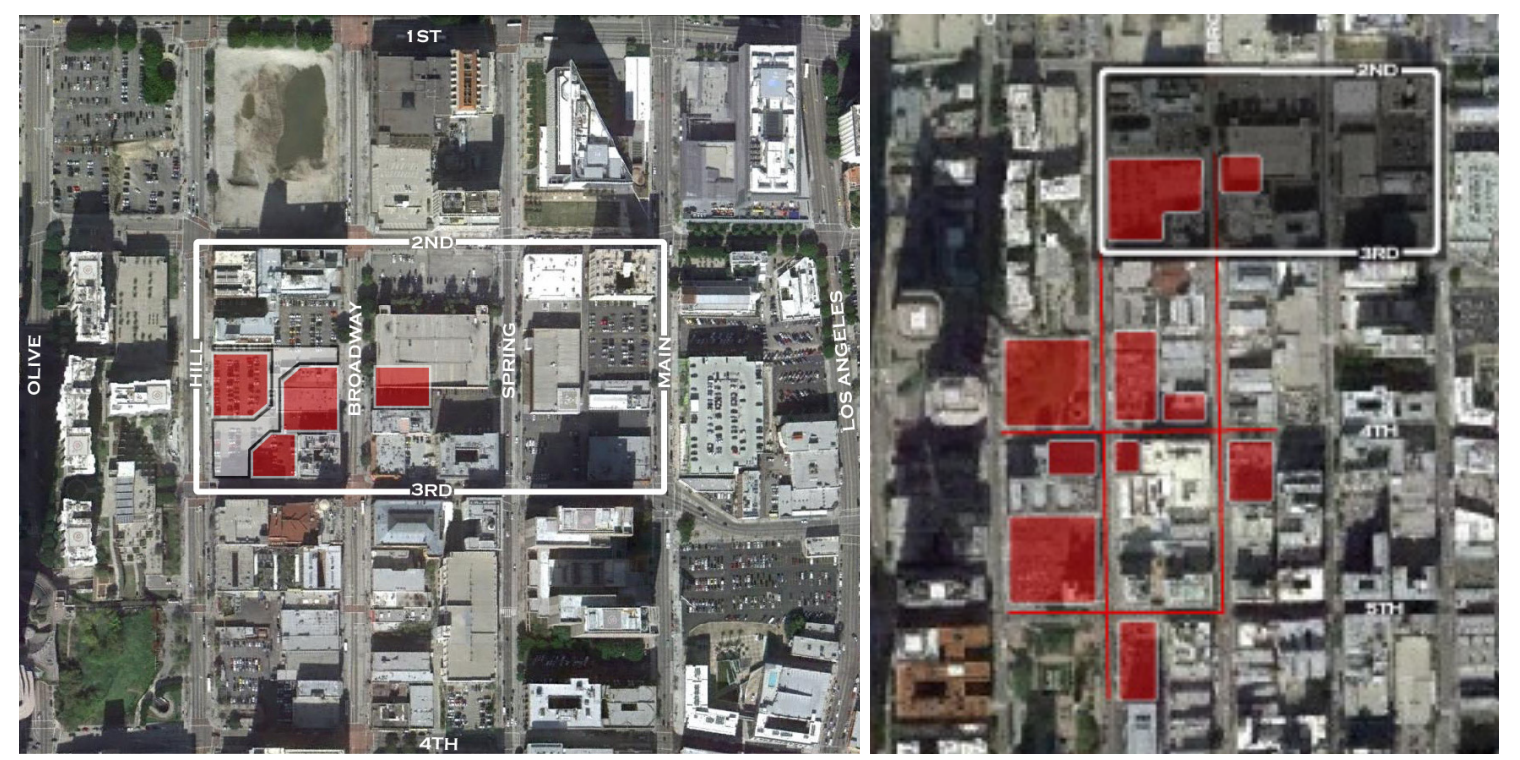

Figure 9.7. Mixed-Use Component land use schematic

Figure 9.8. Proposed and available development sites near the Mixed-Use Component

However, Hill Street is quieter and more residential in character than Broadway. The street also contains more green space and less commercial frontage than the other streets in the area. The plaza at Hill and 3rd Streets is intended to add a pedestrian node and point of transition along the street between the Civic Center and Pershing Square while maintaining the street's more sedate character. (Figure 9.8)

Relevant Case Study: Chinatown Project, San Luis Obispo, CA

\section{Summary}

While significantly smaller in scale than the type of development called for in the Development Study site, the Chinatown Project provides striking parallels with the mixed-use component in terms of urban context, site conditions, and potential design strategies. Specifically, the project provides examples of how new construction can be integrated into a comparable historic urban context, how a site plan can utilize existing topography, and how project components can best be arranged for internal logic and coordination with surrounding development. 


\section{Project Description}

The Chinatown Project is a 226,146 sf mixed-use development being proposed by Copeland Properties. (Figure 9.9) The project would be situated within both the Historic Downtown and the Historic Chinatown sections of San Luis Obispo, CA, and would consist of the following components: retail $(49,925 \mathrm{sf})$; office $(5,630 \mathrm{sf})$; restaurant $(6,000 \mathrm{sf})$, residential condominiums

(16 units); and a 78-room hotel

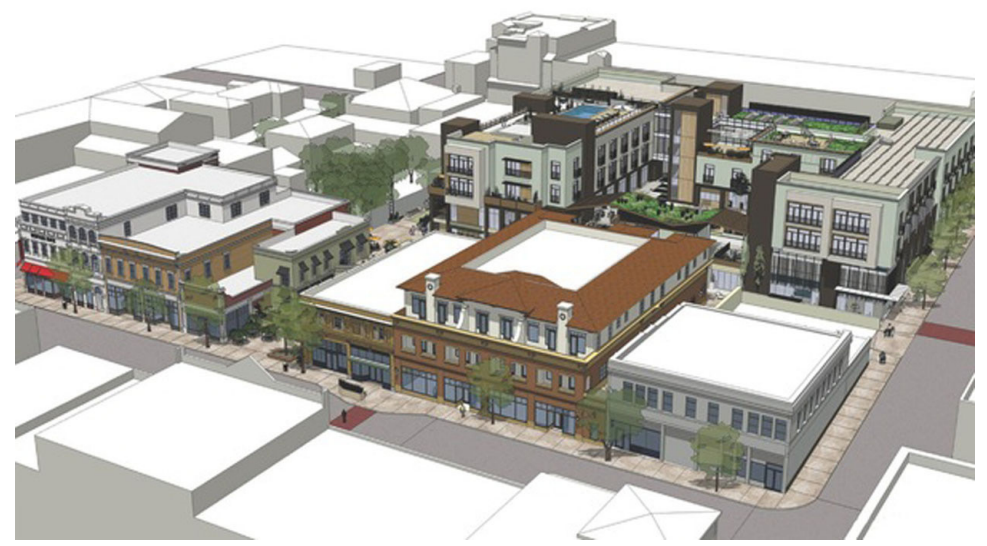

Figure 9.9. Chinatown Project rendering (City of San Luis Obispo, 2009) (85,430 sf). The buildings included in the project range from one to three stories in height, and the project includes one level of underground parking with 74 spaces $(30,000 \mathrm{sf})$. The project has been scaled-down since it was originally proposed and redesigned to preserve a cluster of historic buildings at Chorro and Monterey streets that were originally slated for demolition. (City of San Luis Obispo, 2009)

\section{Relevance to this Study}

Because the Chinatown Project site shares many of the same features and constraints as the Hill Street Plaza and Paseo site, it serves as an example of how the mixed-use component might be designed and developed. The site slopes upward from Monterey Street to Palm Street and historic structures occupy roughly a third of the block. Due to its long history of settlement and its proximity to the historic Mission, the site is also likely to be archeologically sensitive.

Furthermore, the larger urban and historic context of the site provides insights into the unique opportunities and challenges of developing the Los Angeles site. Prior to the 20th century, the growth of San Luis Obispo followed a similar trajectory to that of Los Angeles. Both cities were originally colonized by the Spanish in the late 18th century. Like Los Angeles, San Luis Obispo is located far inland from its primary port of access at Port San Luis, to which it was connected originally by the Pacific Coast Railway. And like Los Angeles, the development pattern of San 
Luis Obispo had already been firmly established by a succession of Native American, Spanish, Mexican, and American settlers by the time the Southern Pacific arrived in 1894, connecting the city to San Francisco. (Dandakar \& Jordan, 2011)

Because of these parallels, Downtown San Luis Obispo provides a unique glimpse of Downtown Los Angeles' lost urban fabric and context. In its architecture, civic functions, and traces of pre-US history, Monterey Street is roughly analogous to North Main Street in Los Angeles as it existed prior redevelopment. Palm Street, the site of San Luis Obispo's Historic Chinatown, resembles Los Angeles' original Chinatown (located where Union Station stands today) in form and historic function.

\section{$\underline{\text { Design Features }}$}

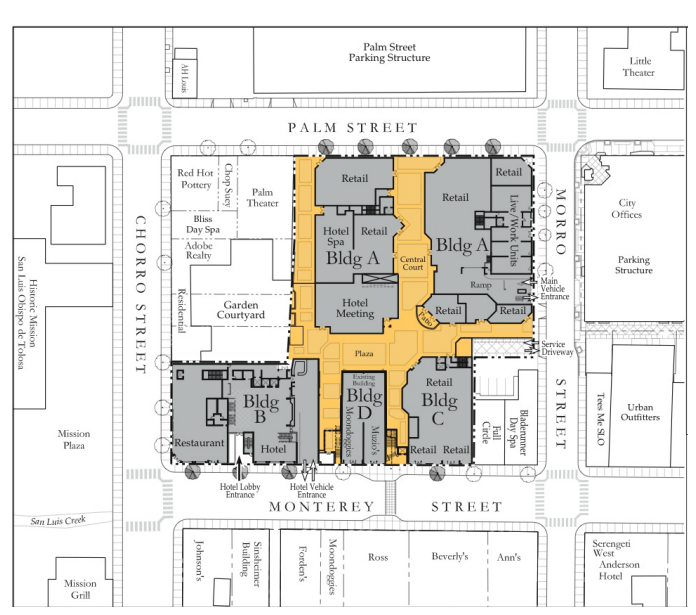

Figure 9.10. Chinatown Project site plan (City of San Luis Obispo, 2009)
A major feature of the Chinatown project is its pedestrian plaza located in the center of the project and accessible from Morro, Palm, and Monterey Streets. (Figure 9.10) The pedestrian plaza and Monterey Street are the focal points for the project's retail, office, and hotel uses. Frontage along Monterey Street is designed to fill gaps in the street wall and establish continuity of scale, rhythm, and architectural detail with the rest of the street. Subterranean parking access is provided along the Morro Street elevation directly across

from the entrance to the Palm Street garage and city offices. Hotel and restaurant entrances are accessible via Palm Street. The Chorro Street elevation retains the existing street frontage while adding new retail. (City of San Luis Obispo, 2009) 


\section{Component 3: Residential}

\section{Design Description}

The 1993 Downtown Strategic Plan identified the area around St. Vibiana Cathedral as the focus for infill residential development. Pursuant to this goal, the residential component calls for the development of the lot adjacent to the Higgins building, which would fill a significant gap in Main Street's street wall while adding additional street level retail to the corridor. (Figure 9.11) Development of this site could also act as a catalyst for additional residential and commercial development along this stretch of Main Street. The design could also be coordinated with development along Spring Street to incorporate a pedestrian arcade between Main and Spring streets. (Figure 9.12)

The Stimson Building lot at the northeast corner of 3rd \& Spring is another important catalytic site. (Figure 9.12) The site, located at the northern end of the former "Wall Street of the West," currently serves as a parking lot and is the only vacant parcel at this intersection. While the two western corners contain large historic buildings (the Douglas Building and the Washington Building), the southeast corner is occupied by the Reagan Office Building, which dominates its surroundings with its scale and massing, contributes little to street life, and creates incongruity
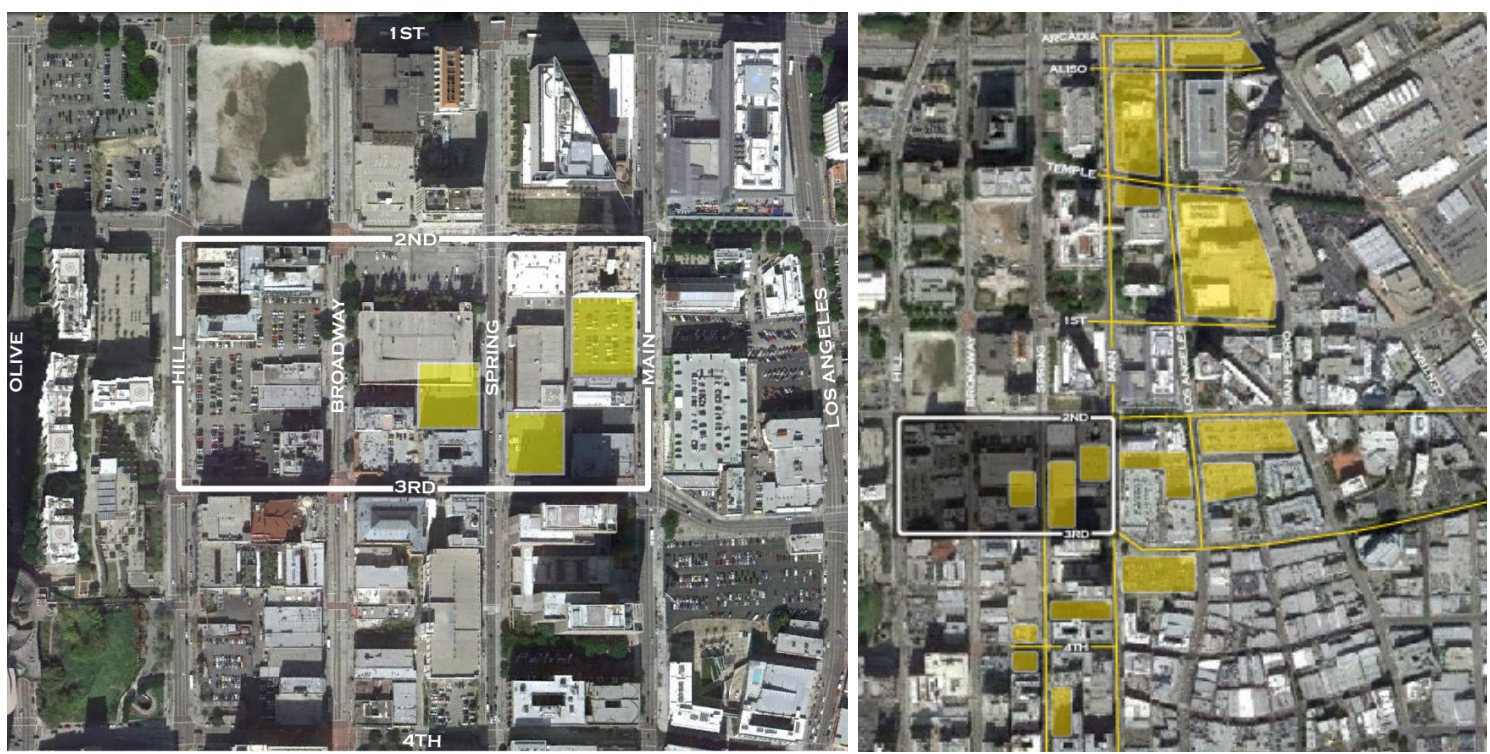

Figure 9.11. Residential Component land use schematic

Figure 9.12. Proposed and available development sites near the Residential Component 
and a visual barrier between Civic Center South and the Historic Core. With appropriate design and detailing, development of the Stimson Building lot could help mitigate the monolithic scale, massing, and features of the Reagan Office Building and fill the gap that currently exists there.

Relevant Case Study: Union Row, Washington, DC

\section{$\underline{\text { Summary }}$}

Union Row is similar in scale, massing, and façade treatment to the type of infill development called for in the Downtown Los Angeles Design Guide. The project's street level retail treatment would also be suitable for the building frontages along Main and Spring Streets. The treatment of the alleyway could also be applied to the Development Study site.

\section{Project Description}

Union Row is a mid-rise residential project located near the $U$ Street corridor of Washington, DC. The project consists of two separate properties. The Flats is a nine-story, 208-unit condominium building with 27,000 square feet of ground-floor retail. (Figure 9.13) The Warehouses consists of a pair of adaptively reused warehouses containing 59 multi-level townhouse condominiums surrounding a central courtyard. The project was

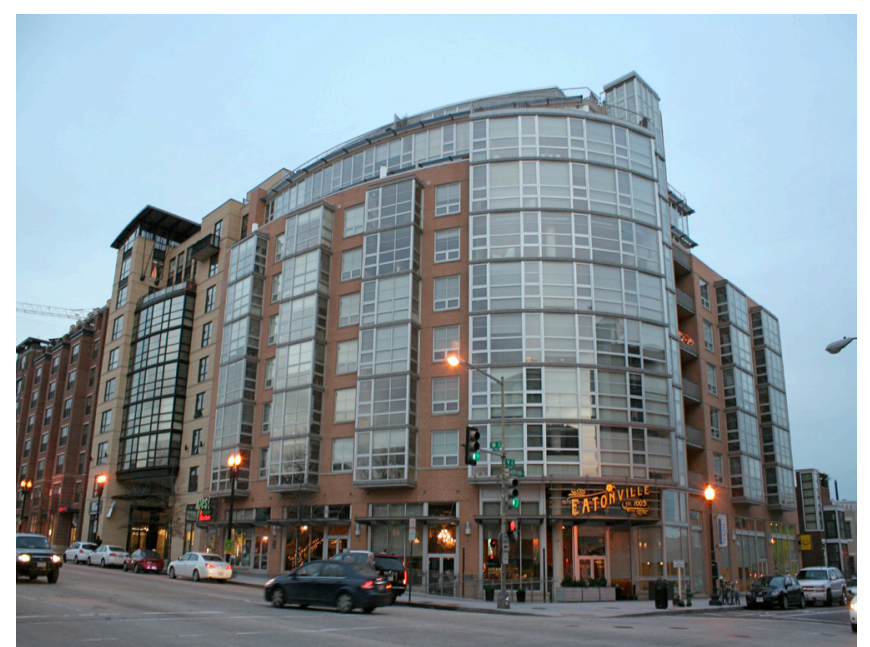

Figure 9.13. The Flats, Union Row, Washington, DC developed by PN Hoffman and designed by SK\&I Architectural Design Group. The project is one of several residential infill projects completed or in development along the $U$ Street Corridor, an area of intense redevelopment over the past two decades. The project has won the National Association of Home Builder's Pillars of the Industry Award and was cited by the Urban Land Institute in its Best Practices in Development. (Thoerig, et al., 2009) 


\section{Relevance to this Study}

Union Row provides an optimal case study for the type of infill development suitable for the residential component of this development study. The project itself is comparable in scale and footprint to potential development sites along Main and Spring Streets. The massing, façade, and street-level commercial treatments are also directly applicable to the design imperatives of the component site. Finally, the interior courtyard provides design examples for the frontage along Harlem Alley and a possible mid-block pedestrian walkway between Spring and Main Streets.

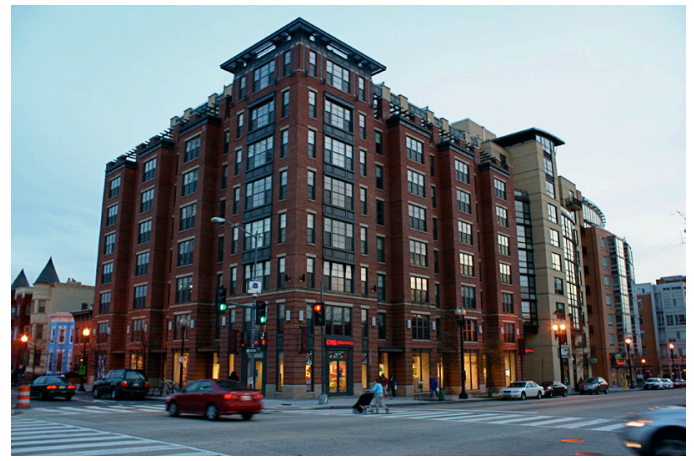

\section{Design Features}

The façade of the Flats is divided into three sections, which breaks up the massing of the blocklong building along 14th Street while still contributing to a strong street wall. (Figures 9.14 and 9.15) An existing alley that runs through the site has been converted to a hardscaped courtyard that provides access to interior ground floor office spaces and townhouses. The newly constructed upper stories of the townhouses are set back from the alley, creating a terraced effect that complements the open space below. (Thoerig, et al., 2009)

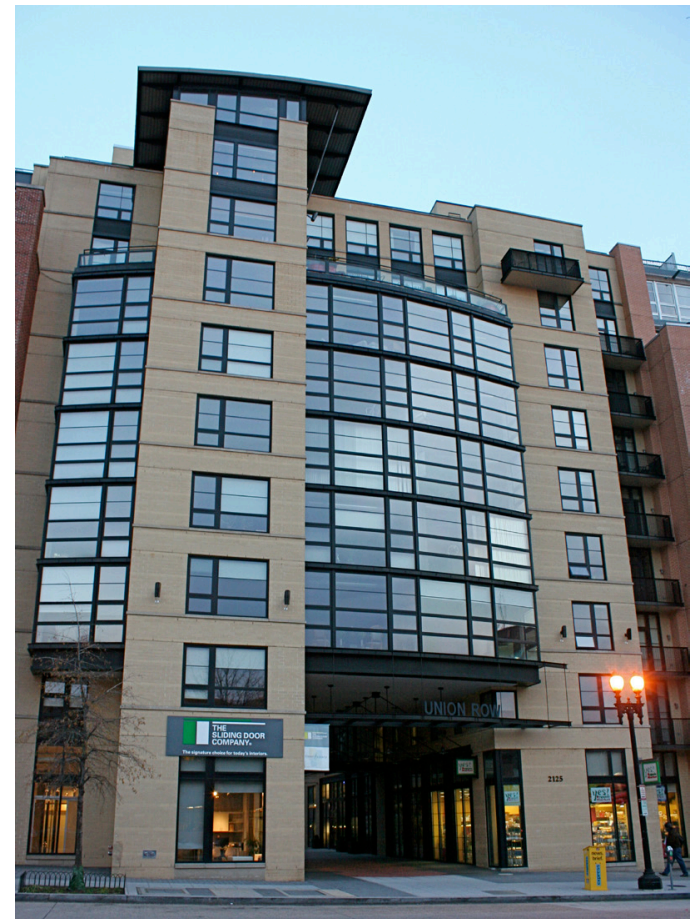

Figures 9.14 \& 9.15. Facade differentiation, The Flats, Union Row, Washington, DC 


\section{Pedestrian Corridors}

\section{Crosstown Corridor}

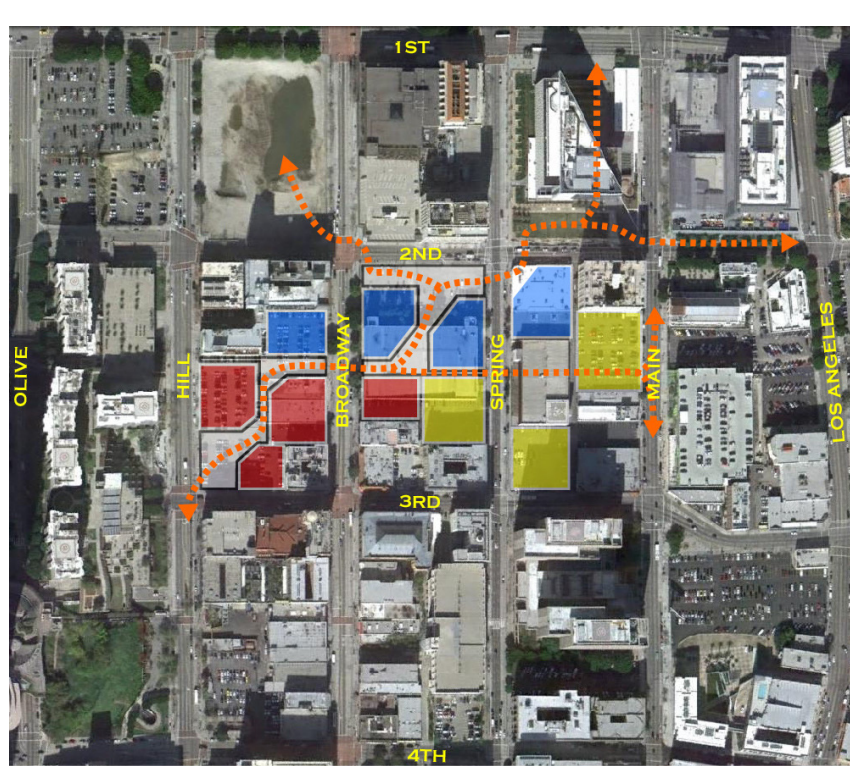

Figure 9.16. Crosstown Corridor Diagram

In the Civic Center, the primary corridors are Main and Spring Streets, as described in the Civic Crossroads Plan. In the northern end of the Historic Core, the primary corridors are Spring Street and Broadway, as described in the 1993 Downtown Strategic Plan. The Crosstown Corridor facilitates this eastwest transition in primary corridors for pedestrians moving between the Civic Center and the Historic Core, as well as pedestrians entering the area from the east via the 2nd Street corridor. (Figure 9.16)

\section{Hill Street Corridor}

The mixed use component would bolster the Hill Street Corridor by creating a plaza and commercial attractions at the corner of 3rd and Hill Streets. (Figure 9.17) The plaza would provide a useful transition point in terms of attractions and topography, providing a diagonal, commercial-lined shortcut to the new Broadway and 2nd Street Subway Station.

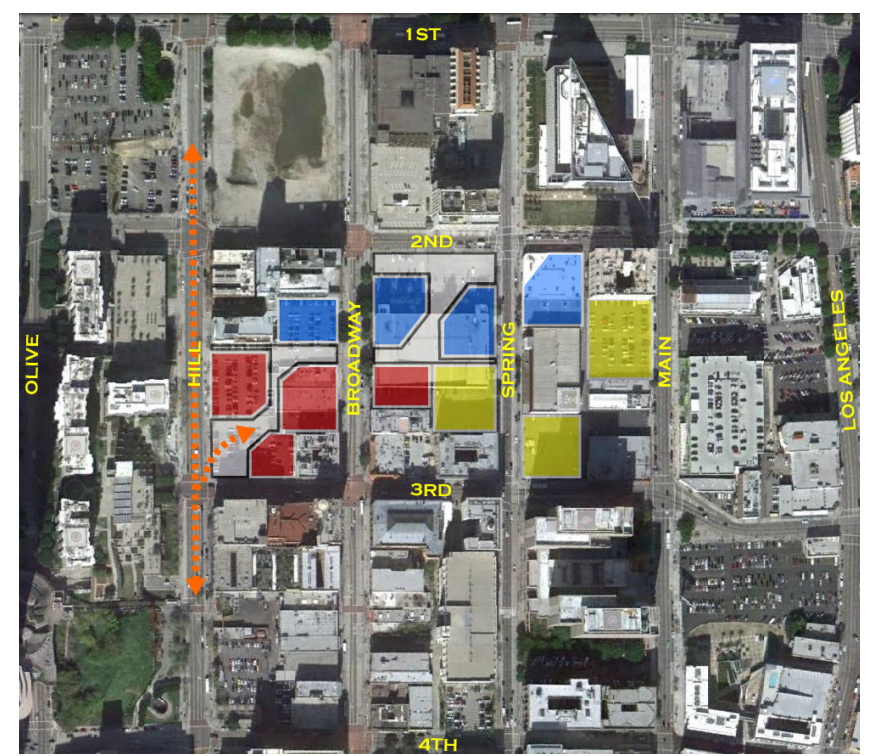

Figure 9.17. Hill Street Corridor Diagram 


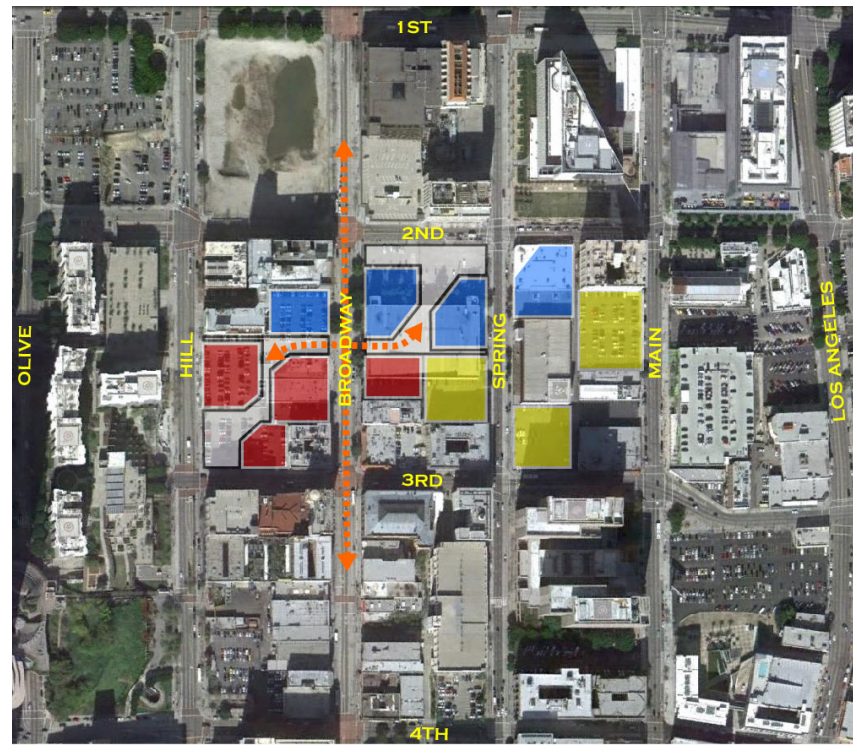

Figure 9.18. Upper Broadway Corridor Diagram
Along with Spring Street, this segment of Broadway serves as an important transitional area between the civic functions to the north and the commercial and entertainment functions to the south. On Broadway, this transition is particularly sharp and defined by the mid-block paseo, which serves as the dividing line between these two districts. This paseo also adds a crosstown dynamic to Broadway, with the subway and office district to the east and the quiet repose of

the plaza to the west. (Figure 9.18) Redevelopment should articulate these transitions and bolster the distinct subareas along this corridor through architecture, massing, and land use.

\section{Spring Street Corridor}

Like Broadway, Spring Street is an important transitional corridor. To the north, the built environment is dominated by the monumental architecture and open spaces of the Civic Center. To the south, only two remaining buildings - the Douglas Building and the Washington Building - provide the physical and historical link between the 19th century downtown and 20th century office buildings south of 4 th Street. Office and residential development along Spring Street can help articulate this transition.

(Figure 9.19)

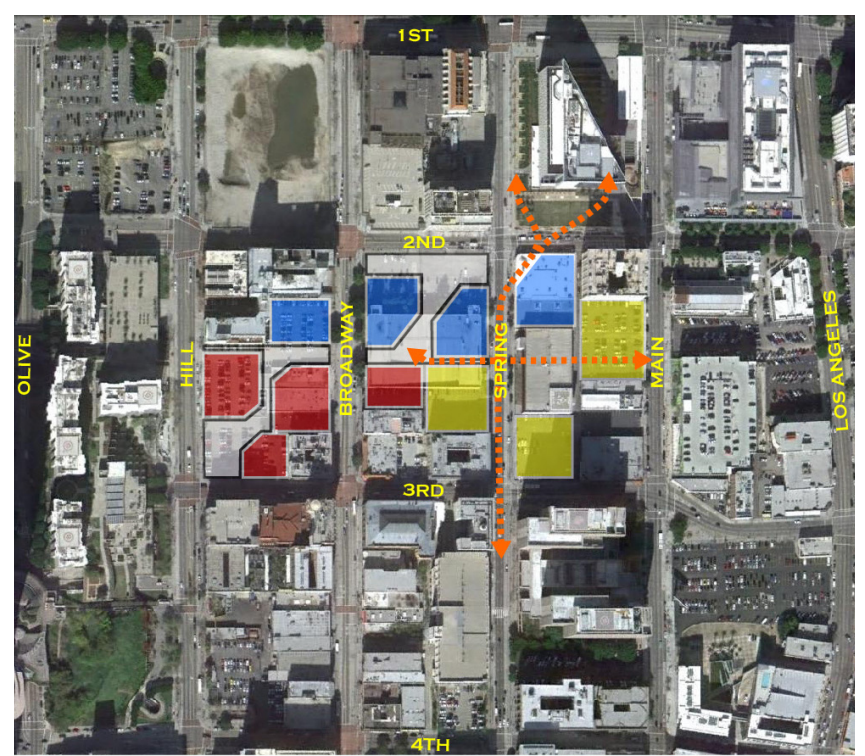

Figure 9.19. Spring Street Corridor Diagram 


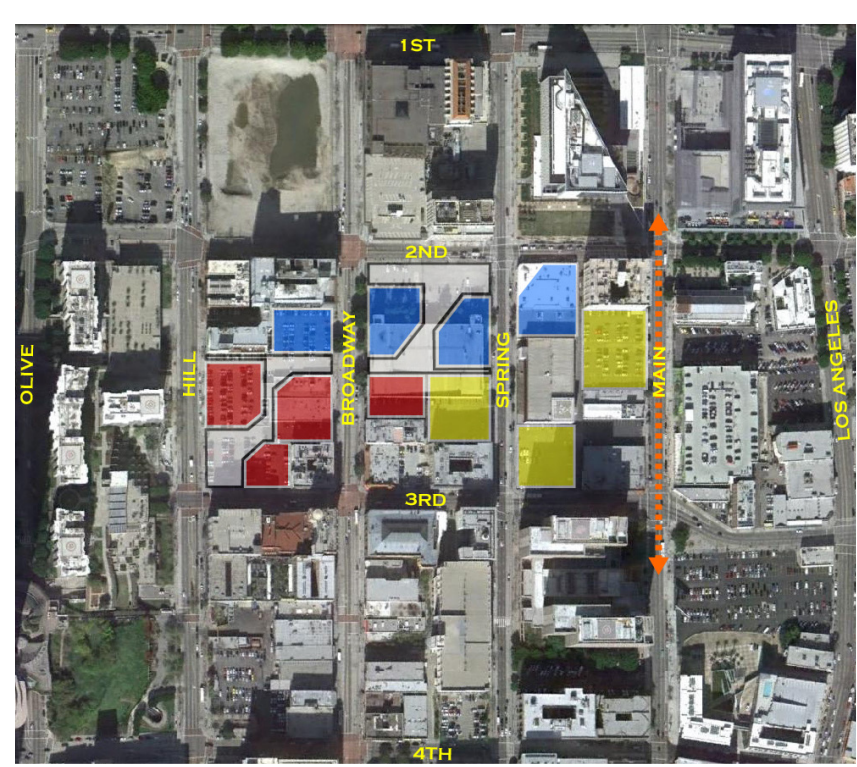

Infill development can restore the street wall and enhance the pedestrian environment along this section of Main Street. It would also bolster the gateway at Main and 2nd Streets called for in the Civic Crossroads Plan and articulate the transition between the Historic Core, the Civic Center, and Little Tokyo. (Figure 9.20)

Figure 9.20. Main Street Corridor Diagram 
Chapter 10. Conclusions 


\section{Research Questions Answered}

The purpose of this study was to determine how an understanding of Civic Center South's historic development trajectory could inform new development and contemporary urban design and restore a pedestrian scale and urban continuity to the area. The study also explored how such historically-informed development strategies could be pursued while also meeting the demands of current land use policies, economic imperatives, and urban design standards.

Based upon the research and the development study presented in this thesis, not only can the historic context inform new development and urban design in the study area, it already is doing so. The historic analysis presented in this thesis provided the first step for determining opportunity sites and setting urban design goals. The historic context also revealed the distinct character of the Civic Center South site, which served as Los Angeles' central business district in the late 19th century before being superseded in the 20th century. Finally, the historic context provided the overriding organizing principle for the design recommendations presented in the development study.

Those recommendations also represent a synthesis of existing city policies as well as comparable development already occurring in Los Angeles and other US cities. City policies reflected in the development study recommendations include the design guidelines for Downtown, the Historic Core and the Broadway Corridor; the 1993 Downtown Strategic Plan; and city ordinances for residential development, parking, and adaptive reuse. Contemporary development reflected in development study recommendations include the case studies presented in that chapter, the LAPD Headquarters, the Park 101 project, the Regional Connector, and the Project Restore master plans.

In summary, the historic context of the Civic Center area can inform new development and urban design within that area. And in fact the city is successfully laying the groundwork for ensuring that new development and urban design contributes to the restoration of pedestrian scale and urban and historical continuity within the Civic Center area. 


\section{Other Considerations}

The Civic Center South site is a key opportunity site within the overall study area. However, in some ways it is also the "low-hanging fruit" of the study area and is less representative of the challenges in promoting historically-informed, context sensitive development elsewhere within the study area. Despite its deteriorated condition, the site remains relatively intact, retaining its original street network, lot subdivision, and fine-grained urban scale. The site also retains numerous assets, including historic buildings, local businesses, and continuity of character. With the exception of the Times parking garage, the site has not experienced the kind of large-scale redevelopment that has occurred north of 2 nd Street. As a result, the Civic Center South site is therefore more comparable in character and development potential to the Historic Core than it is to the other two opportunity sites.

Development north of 2 nd Street will likely continue to be dominated by large-scale projects on consolidated parcels controlled by singular, powerful, and often governmental entities. Therefore, broad city policies such as design guidelines and area-wide ordinances are unlikely to be as effective north of 2 nd Street as they have been in the historic core, where property is less consolidated, the desired urban form has already been established, and a more diverse mix of land uses is more feasible. Implementation of historically-informed development strategies within the Civic Center will inevitably need to be advanced on a project-by-project basis rather than through broadly applied policies and guidelines. Master plans such as the Civic Crossroads and the First Street Now! plans are probably the most effective tools for developing and implementing such development strategies.

Large-scale redevelopment proposals will therefore play a larger role north of 2nd Street in restoring a pedestrian scale and physical and historical continuity to the area. The LAPD Headquarters provides a promising example of how the conditions of previous lot consolidation, current economies of scale, and the design imperatives of a civic institution client can be reconciled with urban design goals of connectivity and urban restoration. On an even grander scale, the Park 101 project is an example of a large-scale redevelopment intervention intended specifically to repair the damage caused by earlier eras of redevelopment. Both of these examples suggest that although large-scale property ownership patterns established during the redevelopment era may be permanent, historically-informed urban development strategies can 
still guide new development and urban design to restore a pedestrian scale and continuity in urban form and history. Specifically, if guided by such strategies, new development can avoid or mitigate the type of upheaval that characterized earlier eras of redevelopment and urban design can be utilized to avoid or reconcile discontinuities in urban form and scale. 


\section{BIBLIOGRAPHY}

Abu-Lughod, J. L. (1999) New York, Chicago, Los Angeles: America’s global cities. Minneapolis, MN: University of Minnesota Press.

AECOM (2012). Los Angeles Police Department (LAPD) Headquarters. Retrieved from http:// www.aecom.com/What+We+Do/Architecture/_projectsList/Los+Angeles+Police+Departm ent+\%28LAPD\%29+Headquarters

AECOM (2012). Park 101. Retrieved from http://www.aecom.com/What+We+Do/

Design+and+Planning/Market+Sectors/Transportation/Livable+Transportation/_carousel/ Park+101

Antczak, A., Mangan, M., \& Shute, A. (n.d.) Designing the Civic Center and the sprawling 20's. History of Planning in Los Angeles. Retrieved from http://laplanninghistory.wordpress. com/1913-1941/

BAK (2010, May) The J.W. Robinson co., Los Angeles. From The department store museum. Retrieved from http://departmentstoremuseum.blogspot.com/2010/05/jw-robinson-co-losangeles.html

Barholomew, H., Cheney, C.H., \& Olmsted, F.L. (1924) A Major Traffic Street Plan for Los Angeles. The Traffic Commission of the City and County of Los Angeles. Los Angeles, CA Bariscale, F.B. (2008, August 28). No. 177 - Subway Terminal Building. Big Orange Landmarks: Exploring the landmarks of Los Angeles, one monument at a time. Retrieved from http:// bigorangelandmarks.blogspot.com/2008/08/no-177-subway-terminal-building.html

Brasuel, J. (2012). Back from the dead: Long-dormant plans for federal courthouse in Downtown LA finally move ahead. The Architects Newspaper. January 25, 2012. Retrieved from http://archpaper.com/news/articles.asp?id=5858

Budokan of Los Angeles. (n.d.) website. Retrieve at http://budokanoflosangeles.com/

California Department of Transportation. (n.d.) District $7 \mathrm{HQ}$ building tour guide. Retrieved from http://www.dot.ca.gov/dist07/aboutus/building/

Caltrans District 7 Headquarters. (n.d.) Retrieved May 12, 2012 from the Caltrans District 7 Headquarters wiki: http://morphopedia.com/projects/caltrans-district-7-headquarters

Cathedral of Saint Vibiana. (n.d.) Retrieved May 12, 2012 from the Cathedral of Saint Vibiana wiki: http://en.wikipedia.org/wiki/Cathedral_of_Saint_Vibiana

City of Los Angeles (2012) Bringing Back Broadway. Retrieved from http://bringingbackbroadway. com/index.htm 
City of Los Angeles. (2012) Municipal Code. American Legal Publishing Corporation. Retrieved from http://www.amlegal.com/nxt/gateway.dll/California/lamc/municipalcode?f=templates\$ $\mathrm{fn}=$ default.htm $\$ 3.0 \$$ vid=amlegal:Iamc_ca

City of Los Angeles. (2011). El Pueblo de Los Angeles historic monument. Retrieved from http:// elpueblo.lacity.org/

City of Los Angeles. (2007). Executive Summary. Green LA: An Action Plan to Lead the Nation in Fighting Global Warming. Retrieved from http://www.ci.la.ca.us/mayor/villaraigosaplan/ EnergyandEnvironment/LACITY_004467.htm

City of Los Angeles. (1993) Downtown Strategic Plan. City of Los Angeles: Los Angeles, California

City of Los Angeles Department of Building and Safety. (2007). Inter-departmental correspondence. (ZI No. 1117, Metro Rail Project Area), Los Angeles, CA

City of Los Angeles Department of City Planning. (2012) Zone Information and Map Access System (ZIMAS) website. City of Los Angeles: Los Angeles, California http://zimas.lacity. org

City of Los Angeles Department of City Planning. (2010) Enterprise Zone/Employment and Economic Incentive Program Area (EZ), ZI No. 2374, revised September 29, 2010. City of Los Angeles: Los Angeles, California

City of Los Angeles Department of City Planning. (2010) Recommendation Report to City

Planning Commission on TFAR, Case No. CPC-2010-213-CA, May 13, 2010. City of Los Angeles: Los Angeles, California

City of Los Angeles Department of City Planning. (2009) Broadway Theater and Entertainment District Design Guide (Community Design Overlay), ZI No. 2408, October 26, 2009. City of Los Angeles: Los Angeles, California

City of Los Angeles Department of City Planning. (2009). Center City Community Plan General Land Use Map. City of Los Angeles: Los Angeles, California

City of Los Angeles Department of City Planning. (2009) Downtown Design Guide. Los Angeles, CA: City of Los Angeles Department of City Planning, Urban Design Studio City of Los Angeles Department of City Planning. (2007) Greater Downtown Housing Incentive Area, ZI No. 2385, September 23, 2007. City of Los Angeles: Los Angeles, California City of Los Angeles Department of Transportation (n.d.) Green Bike Lanes Program First and Spring Streets. Retrieved from http://ladot.lacity.org/pdf/PDF255.pdf 
City of Los Angeles Mayor's Office of Housing and Economic Development. (2006) Adaptive Reuse Program, Second Edition. City of Los Angeles: Los Angeles, California

City of San Luis Obispo (2011) Planning Commission Agenda Report, Item \#3, December 14, 2011

City of San Luis Obispo (2009) Addendum to the Environmental Impact Report for the Chinatown Project (EIR Case No. ER \#69-05, SCH \#2006111012)

Community Redevelopment Agency of the City of Los Angeles (2002) Redevelopment Plan for the City Center Redevelopment Project. Los Angeles, CA

Cornejo, A. (2011). Chinatown project in SLO is going up, slowly, in phases. San Luis Obispo Tribune. Retrieved from http://www.sanluisobispo.com/2011/12/14/1872092/chinatownproject-in-slo-is-going.html

Crouch, D.P. \& Mundigo, A.I., (1977). The city planning ordinances of the Laws of the Indies revisited. Part II: Three American cities. The Town Planning Review, 48(4), 397-418.

Cuff, D. (2000). The provisional city: Los Angeles stories of architecture and urbanism. Cambridge, MA, and London, England: The MIT Press

Dandakar, H. \& Jordan, A. (2011) The railroads and San Luis Obispo's urban form. Focus: Journal of the City and Regional Planning Department, 8 (1), 46-55. California State Polytechnical University, San Luis Obispo.

Davis, M. (1990). City of quartz: Excavating the future in Los Angeles. New York, NY: Vintage Books

Dawson, J. (2008) Los Angeles's Angels Flight. Charleston, SC, Chicago, IL, Portsmouth, NH, San Francisco, CA: Arcadia Publishing

DeVerteuil, G., McCann, L., Roseman, C. C., Taube, D., \& Wallach, R. (2004) The historic core of Los Angeles. Charleston, SC, Chicago, IL, Portsmouth, NH, San Francisco, CA: Arcadia Publishing

DiMassa, C.M. (2008). In L.A.'s nucleus, changing Times. The Los Angeles Times. Retrieved from http://articles.latimes.com/2008/jun/27/local/me-times27

Downtown Los Angeles Center Business Improvement District. (2012) Website.

Electric Railway Historical Association of Southern California. (n.d.). Los Angeles Pacific corporate histories. Retrieved from http://www.erha.org/lap_corphist.htm

Electric Railway Historical Association of Southern California. (n.d.). Second street cable railway. Retrieved from http://www.erha.org/sscr.htm 
Electric Railway Historical Association of Southern California. (n.d.). Temple street cable railway. Retrieved from http://www.erha.org/tscr.htm

Fogelson, R. M. (1967) The fragmented metropolis: Los Angeles, 1850-1930. Berkeley and Los Angeles, CA: University of California Press

Four Level Interchange. (n.d.) Retrieved May 12, 2012 from the Four Level Interchange wiki: http://en.wikipedia.org/wiki/Four_Level_Interchange

Grand Avenue Project. (n.d.) Retrieved May 12, 2012 from the Grand Avenue Project wiki: http:// en.wikipedia.org/wiki/Grand_Avenue_Project

Griswold del Castillo, R. (1979) The Los Angeles barrio, 1850-1890: A social history. Berkeley and Los Angeles, CA: University of California Press

Groth, P. (1994). Living downtown: The history of residential hotels in the United States. Berkeley and Los Angeles, CA: University of California Press

Guzman, R., (2010). Medallion's double gamble. Los Angeles Downtown News. July 16, 2010. Retrieved from http://www.ladowntownnews.com/news/medallion-s-double-gamble/ article_b3534495-8985-563d-b64e-e5790861efc6.html

Guzman, R., Regardie, J., Vaillancourt, R. (2012). Bringing back the building: The latest information on 70 Downtown projects. Los Angeles Downtown News. February 17, 2012. Retrieved from

Heights of Buildings Act of 1910. (n.d.) Retrieved May 12, 2012 from the Heights of Buildings Act of 1910 wiki: http://en.wikipedia.org/wiki/Heights_of_Buildings_Act_of_1910

Hise, G. (2001) "Nature's workshop" industry and urban expansion in Southern California, 19001950. Journal of Historical Geography. 27(1), 74-92

Hsu, B. (2011, July 5). North side of First street between San Pedro street and Los Angeles street, 1940s-2011. Urban Diachrony. Retrieved from http://urbandiachrony.wordpress. com/2011/07/05/north-side-of-first-street-between-san-pedro-street-and-los-angelesstreet-1940s-2011/

JFAK Architects. (n.d.) LAPD motor transport division + Main street parking. Retrieved from http:// www.jfak.net/projects/42

Kostof, S. (1991). The city shaped: Urban patterns and meanings through history. Boston, New York, Toronto, London: Bullfinch Press

LA Downtown News (2012) Pity those stuck at Parker Center. LA Downtown News. April 12, 2012. Retrieved from http://www.ladowntownnews.com/opinion/pity-those-stuck-atparker-center/article_929e8922-85b5-11e1-a042-001a4bcf887a.html 
Longstreth, R. (1997) City center to regional mall: Architecture, the automobile, and retailing in Los Angeles, 1920-1950. Cambridge, MA: M.I.T. Press

Los Angeles Conservancy. (2008). Spanning history: The bridges of the Los Angeles River. Retrieved from http://folar.org/wp-contentuploads/2011/04/spanninghistory_booklet.pdf Los Angeles Conservancy. (2002) Historic Downtown Los Angeles Design Guidelines. Los Angeles, CA: Architecture Resources Group, Architects, Planners \& Conservators, Inc. Los Angeles County Metropolitan Transportation Authority (2012). Regional Connector Transit Corridor. January 17, 2012. Retrieved from http://www.metro.net/projects/connector/ Masters, N. (2012). Lost tunnels of Downtown L.A. L.A. as subject. January 4, 2012. Los Angeles, CA: KCET.org - Community Television of Southern. Retrieved from http://www.kcet.org/ updaily/socal_focus/history/la-as-subject/lost-tunnels-of-downtown-la.html

McCann, L., Roseman, C. C., Taube, D., Wallach, R., \& Zachary, C. (2008) Historic hotels of Los Angeles and Hollywood. Charleston, SC, Chicago, IL, Portsmouth, NH, San Francisco, CA: Arcadia Publishing

Metro Transportation Library (2012). Pacific Electric Railway (1901-1965). Los Angeles County Metropolitan Transportation Authority. Retrieved from http://metrotransportationlibrary. wikispaces.com/Pacific+Electric+Railway+\%281901-1965\%29

Metz, E. (2012). Locally preferred alternative selected. March 13, 2012. goLAstreetcar.org. Los Angeles, CA: Los Angeles Streetcar, Inc. Retrieved from http://www.lastreetcar. org/2012/03/13/locally-preferred-alternative-selected/

Moule, E. \& Polyzoides, S., (2005) The five Los Angeleses. In A. Loomis and G. Ohland (Eds.) Los Angeles: Building the polycentric region (pp. 5-26). Chicago, IL: Congress of New Urbanism

Orange Empire Railway Museum (2012). Hill street tunnels. Perris, CA: OERM. Retrieved from http://www.oerm.org/pages/LARy\%20hillst.htm

Project Restore (2010) Project Restore website. Retrieved from http://projectrestore.lacity.org/ Project Restore (2006) Civic Crossroads Plan. Prepared by Suisman Urban Design, Cambell \& Cambell, \& Rios Clemente Hale Studios. City of Los Angeles. Retrieved from http:// projectrestore.lacity.org/

Project Restore (2005) First Street/Calle Primera. Prepared by Suisman Urban Design, Cambell \& Cambell, \& Rios Clemente Hale Studios. City of Los Angeles. Retrieved from http:// projectrestore.lacity.org/ 
Rappaport Retail Brokerage (n.d) 1000 Connecticut Avenue, NW (building flyer). Retrieved from www.rappaportco.com/

Rice, C. (2008). Second Street Cable Railway. On Bunker Hill. July 15, 2008. Retrieved from http://onbunkerhill.org/node/156

Richardson, E. (2011), 60 years ago: Hollywood freeway opened through Civic Center. Blogdowntown. December 20, 2011. Retrieved from http://blogdowntown. com/2011/12/6532-60-years-ago-hollywood-freeway-opened-through

Richardson, E. (2011). Out of public eye, Regional Connector planning raises concerns. Blogdowntown. September 17, 2011. Retrieved from http://blogdowntown. com/2011/09/6392-out-of-public-eye-regional-connector-planning

Richardson, E. (2010). Swap proposed: Courthouse site for Parker Center. Blogdowntown. July 23, 2010. Retrieved from http://blogdowntown.com/2010/07/5528-swap-proposedcourthouse-site-for-parker

Richardson, E. (2009). Inside the new LAPD headquarters. Blogdowntown. September 3, 2009. Retrieved from http://blogdowntown.com/2009/09/4651-inside-the-new-lapd-headquarters

Richardson, E. (2009). Tribune pulls Times Mirror Square off the market, still seeking leases. Blogdowntown. February 25, 2009. Retrieved from http://blogdowntown. com/2009/02/4087-tribune-pulls-times-mirror-square-off-the

Richardson, E. (2008), Fifty-eight years ago today: Hollywood freeway opens through downtown. Blogdowntown. December 27, 2008. Retrieved from http://blogdowntown. com/2008/12/3922-fiftyeight-years-ago-today-hollywood-freeway

Richardson, E. (2008). Third street tunnel: A primer. Blogdowntown. September 5, 2008. Retrieved from http://blogdowntown.com/2008/09/3589-third-street-tunnel-a-primer Several, M. (1997). Public art works in the Los Angeles Civic Center and the Los Angeles Mall. Los Angeles, December 1997. Public art in Los Angeles, http://www.publicartinla.com/ CivicCenter/

Shannon, J.S. (2009). The Bryson-Bonebreak block, From Los Angeles past: A vanished city lives again. November 4, 2009. Retrieved from http://losangelespast.blogspot.com/2009/11/ bryson-bonebrake-block.html

Sotero, D. (2012). Metro board certifies final environmental study for Regional Connector. The Source: Transportation News \& Views. April 26, 2012. Los Angeles, CA: LACMTA. Retrieved from http://thesource.metro.net/2012/04/26/metro-board-certifies-finalenvironmental-study-for-regional-connector/ 
Spivak, D. R. (1998) History of Skid Row. Los Angeles, CA; Community Redevelopment Agency (CRA)

Stargel, C. \& Stargel, S. (2009) Early downtown Los Angeles. Charleston, SC, Chicago, IL, Portsmouth, NH, San Francisco, CA: Arcadia Publishing

Thoerig, T.C., et al. (2009) Best practices in development: ULI Award Winning Projects 2009. Washington, D.C.: Urban Land Institute

Treaty of Guadalupe Hidalgo. (n.d.) Retrieved May 12, 2012 from the Treaty of Guadalupe Hidalgo wiki: http://en.wikipedia.org/wiki/Treaty_of_Guadalupe_Hidalgo

U.S. National Park Service, (n.d.). Little Tokyo historic district. Retrieved from http://www.nps.gov/ nr/feature/asia/2006/tok.htm

USC Libraries Special Collections, (1996 May 20) Finding aid for the Coulter Dry Goods Company records 0008. Los Angeles, CA: University of Southern California. Retrieved from http://oac.cdlib.org/findaid/ark:/13030/kt6s2038rh

Vaillancourt, R. (2011) Grand Avenue Project to be scaled down. Los Angeles Downtown News. February 9, 2011. Retrieved from http://www.ladowntownnews.com/news/grand-avenueproject-to-be-scaled-down/article_2525d637-39e9-5c42-844b-7435ddcdf6bf.html

Van Ophem, M. (2010). In The iron horse: The impact of the railroads on 19th century American society (chapters 16 \& 18). Retrieved from http://www.let.rug.nl/usa/E/ironhorse/ ironhorse16.htm

Viehe, F. W. (1981) Black gold suburbs: The influence of the extractive industry on the suburbanization of Los Angeles, 1890-1930. Journal of Urban History. 8(3), 3-23

Vincent, R. (2012). City department rents space in Los Angeles Times building. The Los Angeles Times. Retrieved from http://www.latimes.com/business/money/la-fi-mo-city-departmentrents-times-building-20120427,0,2382084.story

Vornado/Charles E. Smith (n.d.) 1000 Connecticut (website). Retrieved from http:// www.1000conn.com/

Walker, J. (2007) Los Angeles Railway yellow cars. Charleston, SC, Chicago, IL, Portsmouth, NH, San Francisco, CA: Arcadia Publishing

Weiss, M.A. (1980). The origins and legacy of urban renewal. In Mitchell, J.P. (Ed.), Federal housing policy \& programs: Past and present (pp. 253-76). 
Yen, B. (2012). One step closer: Downtown LA Little Tokyo Budokan sports complex receives \$5 million state grant. Brigham Yen: Downtown Los Angeles News \& Updates. April 3, 2012. Retrieved from http://brighamyen.com/2012/04/03/one-step-closer-little-tokyo-budokanreceives-5-million-prop-84-grant/

Yen, B. (2012). Simply Salad opening second location in Downtown Los Angeles old bank district. Brigham Yen: Downtown Los Angeles News \& Updates. February 8, 2012. Retrieved from http://brighamyen.com/2012/02/08/simply-salad-opening-second-location-indowntown-los-angeles-old-bank-district/

Yen, B. (2011). New Toriumi Plaza adds open space in Little Tokyo. Brigham Yen: Downtown Los Angeles News \& Updates. October 13, 2011. Retrieved from http://brighamyen. com/2011/10/13/toriumi-plaza-aiso-street-parking-facility-construction-wrapping-up-inlittle-tokyo/\#more-6050

Yen, B. (2011). Budokan sports complex receives Los Angeles city council approval in downtown Los Angeles. Brigham Yen: Downtown Los Angeles News \& Updates. May 18, 2011. Retrieved from http://brighamyen.com/2011/05/18/budokan-sports-complex-receives-losangeles-city-council-approval-in-downtown-los-angeles/ 
Appendix A: Development Chronology 


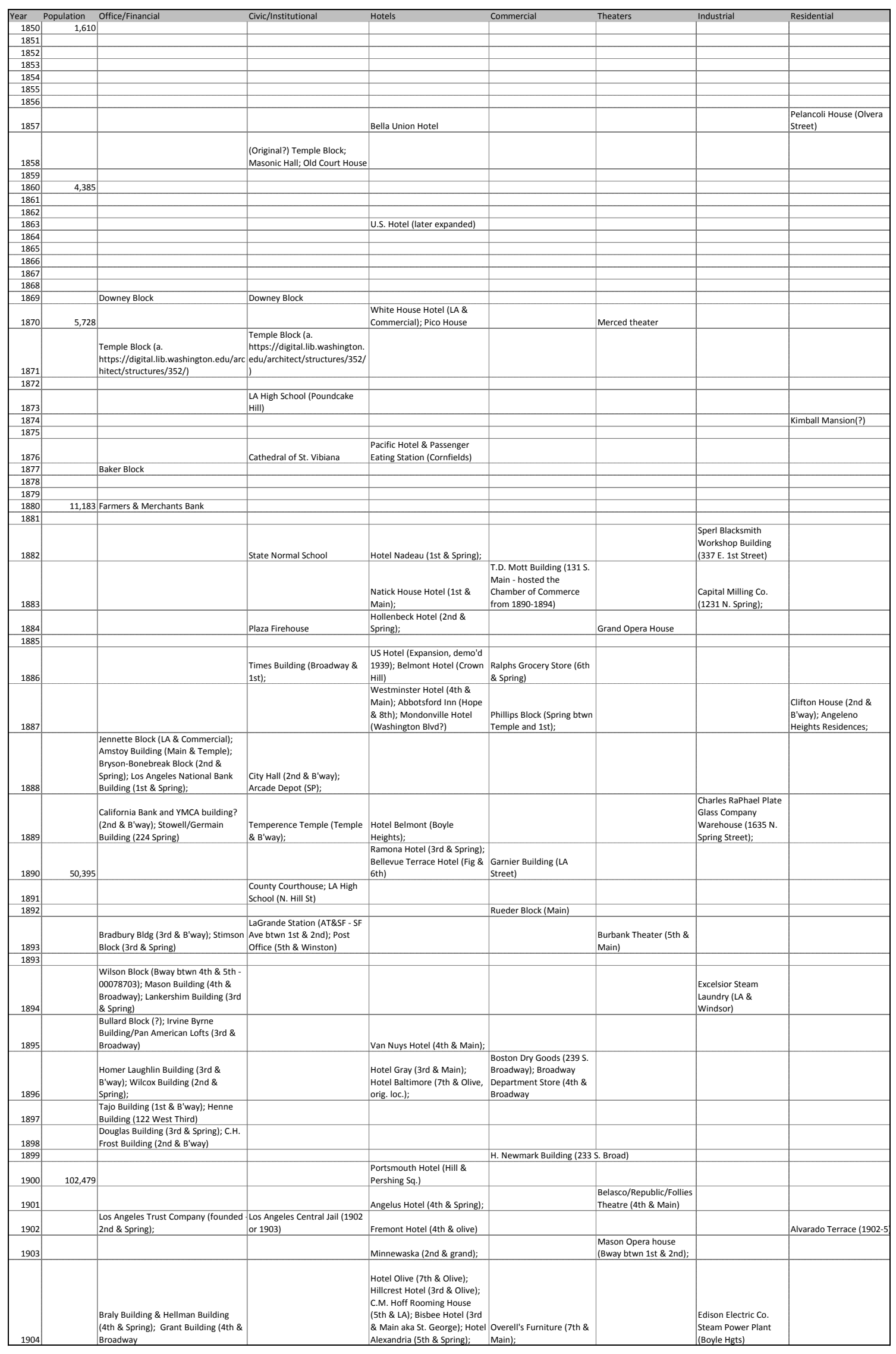




\begin{tabular}{|c|c|c|c|c|c|c|c|c|}
\hline Year & Population & Office/Financial & Civic/Institutional & Hotels & Commercial & Theaters & Industrial & Residential \\
\hline 1905 & & $\begin{array}{l}\text { Security Savings Building (510 S. } \\
\text { Spring); Mercantile Loft Building (6th } \\
\text { \& Main); Farmers \& Merchants } \\
\text { National Bank (4th \& Main); Lyon } \\
\text { Building (3rd \& Hill); Produce } \\
\text { Exchange Building (Towne, Central, } \\
\text { \& 3rd) }\end{array}$ & \begin{tabular}{|l|}
$\begin{array}{l}\text { Pacific Electric Building (6th \& } \\
\text { Main) }\end{array}$ \\
\end{tabular} & $\begin{array}{l}\text { Hotel Rose (9th \& B'way); } \\
\text { Ems Hotel (3rd \& Olive); } \\
\text { Brownstone Hotel (5th \& San } \\
\text { Pedro); Hotel Lindy \& Golden } \\
\text { Gopher Bar (8th \& Olive); }\end{array}$ & & & & \\
\hline 1906 & & $\begin{array}{l}\text { San Fernando Bldg (4th \& Main); } \\
\text { Chamber of Commerce (2nd \& } \\
\text { B'way); }\end{array}$ & & $\begin{array}{l}\text { Alexandria Hotel and Security } \\
\text { Building (5th \& Spring)? - See } \\
\text { above; King Edward Hotel } \\
\text { (5th \& main); Hayward Hotel; } \\
\text { American Hotel (Traction \& } \\
\text { Hewitt, E. Sth); Hotel } \\
\text { Bristo//Woodward (8th \& } \\
\text { Olive); }\end{array}$ & $\begin{array}{l}\text { Bullock's (6th \& B'way); } \\
\text { Hamburgers Dept Store } \\
\text { (801 S. Broadway); }\end{array}$ & $\begin{array}{l}\text { Philharmonic Auditorium } \\
\text { (5th \& Olive); }\end{array}$ & $\begin{array}{l}\text { Barker Brothers } \\
\text { Warehouses \& } \\
\text { Furniture Factories } \\
\text { (Hewitt \& Palmetto, E. } \\
\text { 5th); Cohn \& } \\
\text { Goldwater Overall and } \\
\text { Shirt Factory (12th \& } \\
\text { San Julian); }\end{array}$ & \\
\hline 1907 & & $\begin{array}{l}\text { International Savings Building } \\
\text { (Temple \& Spring); William G. } \\
\text { Kerckhoff Building (6th \& Main); } \\
\text { Cotton Exchange Building (3rd \& } \\
\text { Main) }\end{array}$ & $\begin{array}{l}\text { Charles Mulford Robinson } \\
\text { Civic Center Plan; AT\&SF } \\
\text { Frieght Depot; }\end{array}$ & $\begin{array}{l}\text { Hotel Lankershim (7th \& } \\
\text { B'way); }\end{array}$ & & & $\begin{array}{l}\text { R.L. Craig Wholesale } \\
\text { Grocers (2nd \& Santa } \\
\text { Fe); }\end{array}$ & \\
\hline 1908 & & Gerhard Eshman Building (7th \& Hill) & $\begin{array}{l}\text { U.S. Post Office (Temple \& } \\
\text { Main); }\end{array}$ & & & & & \\
\hline 1909 & & $\begin{array}{l}\text { Canadian Bldg (4th \& Winston); } \\
\text { Consolidated Realty Bldg (6th \& Hill); }\end{array}$ & $\begin{array}{l}\text { engine Co. \#9 Fire Stn (5th \& } \\
\text { Maple); }\end{array}$ & $\begin{array}{l}\text { Baltimore Hotel (5th \& LA - } \\
\text { second location); }\end{array}$ & $\begin{array}{l}\text { Produce Mkt (9th \& San } \\
\text { Pedro); }\end{array}$ & & $\begin{array}{l}\text { Spreckel Brothers } \\
\text { Pacific Hardware \& } \\
\text { Steel Warehouse (E. } \\
\text { 3rd \& Vignes) }\end{array}$ & \\
\hline 1910 & 319,198 & $\begin{array}{l}8 \text { Thomas Higgins Building (108 W. } \\
\text { 2nd) }\end{array}$ & & & & & & \\
\hline 1911 & & $\begin{array}{l}\text { Los Angeles Athletic Club (431 W. } \\
7 \text { th) }\end{array}$ & $\begin{array}{l}\text { Robert A. Rowan Building (458 } \\
\text { S. Spring) }\end{array}$ & & & & & \\
\hline 1912 & & $\begin{array}{l}\text { Title Guarantee Building (500 S. } \\
\text { Broadway) }\end{array}$ & $\begin{array}{l}\text { Hall of Records (Temple \& } \\
\text { Broadway) }\end{array}$ & Clark Hotel (426 S. Hill) & & & & \\
\hline 1913 & & $\begin{array}{l}\text { Metropolitan Building (449 S. } \\
\text { Broadway) }\end{array}$ & & & & & & \\
\hline 1914 & & Citizen's National Bank (453 S. Spring) & 1) Central Station (5th \& Central) & & & & & \\
\hline $\begin{array}{l}1915 \\
1916\end{array}$ & & & 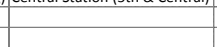 & & & & & \\
\hline 1917 & & & & & & & & \\
\hline 1918 & & & & & & & & \\
\hline 1919 & & & & & & & & \\
\hline 1920 & 576,673 & & & & & & & \\
\hline 1921 & & & & & $\begin{array}{l}\text { Fifth Street Department } \\
\text { Store (501 S. Broadway) }\end{array}$ & & & \\
\hline 1922 & & & & & & & & \\
\hline 1923 & & & & Biltmore Hotel & & & & \\
\hline 1924 & & & & & & & & \\
\hline 1925 & & & $\begin{array}{l}\text { Subway Terminal } \\
\text { Building/Hollywood Subway } \\
\text { Tunnel } \\
\end{array}$ & & & & & \\
\hline 1926 & & $\begin{array}{l}\text { Chester Williams Building (215 W. } \\
\text { 5th St) }\end{array}$ & \begin{tabular}{|l} 
Hall of Justice \\
Central Library
\end{tabular} & & & & & \\
\hline 1927 & & & & & & & & \\
\hline 1928 & & Architects' Building (5th \& Figueroa) & City Hall & & & & & \\
\hline 1929 & & Richfield Building (6th \& Flower) & & $\begin{array}{l}\text { Monarch Hotel (5th \& } \\
\text { Figueroa); }\end{array}$ & & & & \\
\hline 1930 & $1,238,048$ & & & & & & & \\
\hline 1931 & & SoCal Edison Building (5th \& Grand) & & & & & & \\
\hline 1932 & & & & & & & & \\
\hline 1933 & & & State Office Building & & & & & \\
\hline 1934 & & & & & & & & \\
\hline 1935 & & Sunkist Building (Flower \& 5th) & LA Times Building; & & & & & \\
\hline 1936 & & & $\begin{array}{l}\text { LA County Courthouse } \\
\text { demolished }\end{array}$ & & & & & \\
\hline 1937 & & & & & & & & \\
\hline 1938 & & & Terminal Annex Post Office & & & & & \\
\hline 1939 & & & Union Station/Chinatown & & & & & \\
\hline 1940 & $1,504,277$ & & Federal Courthouse & & & & & \\
\hline 1941 & & & & & & & & \\
\hline 1942 & & & & & & & & \\
\hline 1943 & & & & & & & & \\
\hline 1944 & & & & & & & & \\
\hline 1945 & & & & & & & & \\
\hline 1946 & & & & & & & & \\
\hline 1947 & & & & & & & & \\
\hline 1948 & & & & & & & & \\
\hline 1949 & & & & & & & & \\
\hline 1950 & $1,970,358$ & & $\begin{array}{l}\text { LA County Law Library (1950- } \\
\text { 2, expanded 1970-1) }\end{array}$ & & & & & \\
\hline 1952 & & & Hall of Administration & & & & & \\
\hline $1952-4$ & & & & & & & & \\
\hline 1955 & & & Parker Center & & & & & \\
\hline 1958 & & & County Courthouse & & & & & \\
\hline 1960 & $2,479,015$ & & $\begin{array}{l}\text { State Office Building No. } 2 \\
\text { (1st \& Broadway) }\end{array}$ & & & & & \\
\hline 1961 & & & & & & & & \\
\hline 1962 & & & LA Hall of Records & & & & & \\
\hline 1964 & & & Federal Building & & & & & \\
\hline 1966 & & & Criminal Justice Center & & & & & \\
\hline 1970 & $2,816,061$ & & & & & & & \\
\hline 1973 & & & City Hall East & & & & & \\
\hline 1975 & & & & & Los Angeles Mall & & & \\
\hline 1980 & $2,966,850$ & & & & & & & \\
\hline 1986 & & & MOCA; One California Plaza & & & & & \\
\hline 1988 & & & $\begin{array}{l}\text { Metropolitan Detention } \\
\text { Center }\end{array}$ & & & & & \\
\hline 1990 & $3,485,398$ & & Ronald Reagan State Building & & & & & \\
\hline 1991 & & & Edward R. Roybal Building & & & & & \\
\hline 1992 & & & Japanese American National & & & & & \\
\hline 1994 & & & Museum Tower Apartments & & & & & \\
\hline 1998 & & & Colburn School of Arts & & & & & \\
\hline 2000 & $3,694,820$ & & & & & & & \\
\hline
\end{tabular}


Appendix B: Comparative Population Growth of Mid-Western, Southwestern, and Western U.S. Cities 


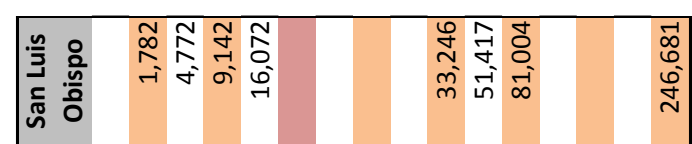

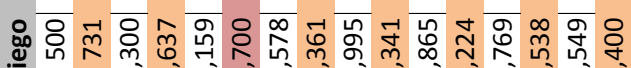

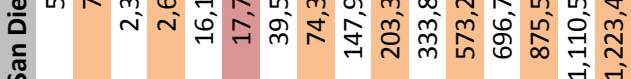

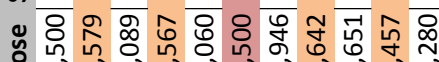

ก๊ ๘ 모

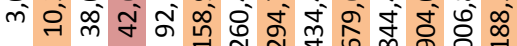
๘

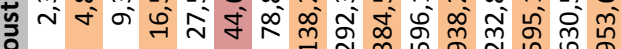

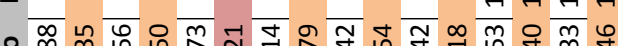
< ๘

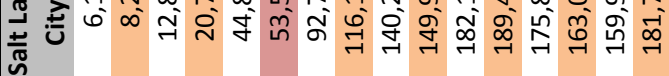
๖ ơ

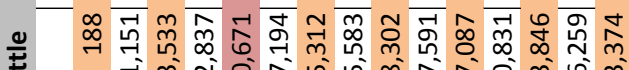
ڤึ 공

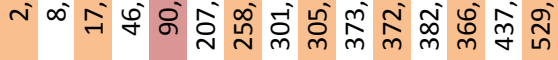

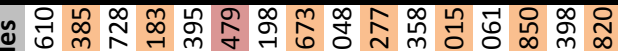

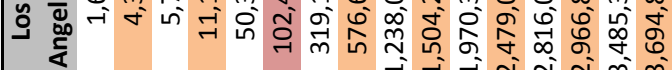
ఇ m 馬

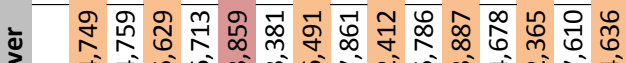

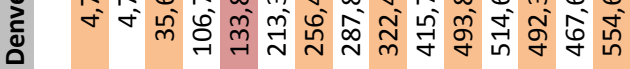

๕

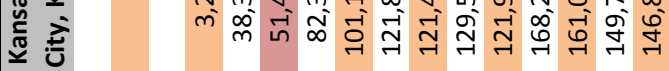
๘

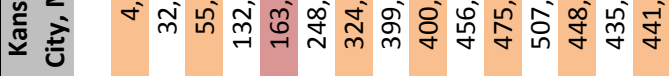

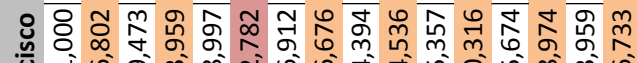

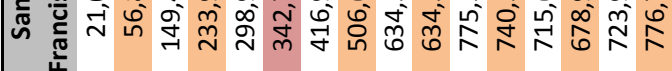

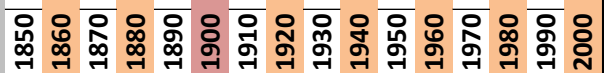




\section{Appendix C: Zoning and Land Use Data for the Development Study Site}




\begin{tabular}{|c|c|c|c|c|c|c|c|c|c|}
\hline Address(es) & Pin & Parcel \# & Qualified & Zone & Height Dis & & MTA Proje & CExisting Building and Uses & Description \\
\hline 108 W 2ND ST (Higgins) & 130-5A213 201 & 5149006BRK & & C4 & 4D & & & 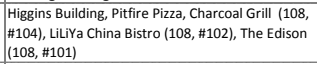 & Residential Conversion; Former Office Building \\
\hline 213-5 S MAIN ST & 130-5A213 104 & 5149006008 & & $\mathrm{C} 4$ & $4 \mathrm{D}$ & & & Parking Lot & Vacant \\
\hline 223 S MAIN ST/216 S HARLEM PL & 130-5A213 107 & 5149006008 & & $\mathrm{C4}$ & $4 \mathrm{D}$ & & & Parking Lot & Vacant \\
\hline None & 130-5A213 113 & 5149006008 & & C4 & 4D & & & Parking Lot & Vacant \\
\hline 231 S MAIN ST/228 S HARLEM PL & 130-5A213 116 & 5149006007 & & $\mathrm{C} 4$ & 4D & & & Parking Lot & Vacant \\
\hline None & 130-5A213 120 & 5149006007 & & $\mathrm{C} 4$ & 4D & & & Parking Lot & Vacant \\
\hline 233-5 S MAIN ST/236S HARLEM PL & $130-5 A 213122$ & 5149006006 & & $\mathrm{C}_{4}$ & $4 \mathrm{D}$ & & & Parking Lot & Vacant \\
\hline $237-43$ S MAIN ST & 130-5A213 131 & 5149006005 & & $\mathrm{C4}$ & $4 \mathrm{D}$ & & & Parking Lot & Vacant \\
\hline 245-7 S MAIN ST/244 S HARLEM PL & 130-5A213 142 & 5149006004 & & C4 & 4D & & & New Jalisco's Bar & One-Story commercial building \\
\hline 249 S MAIN ST & 130-5A213 148 & 5149006004 & & C4 & 4D & & & The Smell nightclub/art space & One-Story commercial building \\
\hline 251 S MAIN ST & 130-5A213 151 & 5149006003 & & C4 & 4D & & & Imagin-Asian Center/Downtown Independent & Single-screen movie theater \\
\hline None & $130-5 A 213156$ & 5149006002 & & $\mathrm{C} 4$ & 4D & & & Parking & Vacant, Narrow Parcel \\
\hline 253-9 S MAIN ST/258 S HARLEM PL & 130-5A213 157 & 5149006002 & $\mathrm{Q}$ & C4 & 4D & & & Parking & Vacant \\
\hline 261 S MAIN ST & $130-5 A 213162$ & 5149006002 & $\mathrm{a}$ & $\mathrm{C4}$ & $4 \mathrm{D}$ & & & Parking & Vacant \\
\hline 263 S MAIN ST & 130-5A213 167 & 5149006001 & a & C4 & 4D & & & Crossfit Mean Streets Fitness & One-Story commercial building \\
\hline 265-9 S MAIN ST & 130-5A213 171 & 5149006001 & $\mathrm{a}$ & $\mathrm{C4}$ & $4 \mathrm{D}$ & & & La Costena Bar, Five Stars Bar & One-Story commercial building \\
\hline 271-3 S MAIN ST/101-19 W 3RD ST & 130-5A213 183 & 5149006001 & Q & C4 & 4D & & & $\begin{array}{l}\text { Shish Kabob Fine Persian Cuisine, Botanica Juan } \\
\text { Soldado, Ricky D's Restaurant (105), Immigration } \\
\text { Services, Paraiso Restaurant }\end{array}$ & One-Story commercial building \\
\hline $200-10$ S SPRING ST/120-32 W 2ND ST & 130-5A213 68 & 5149007006 & & $\mathrm{C} 2$ & 4D & & & $\begin{array}{l}\text { City Employees Club Store \& Member Services } \\
\text { Center (120); 2nd Street Cigars (124); Southland } \\
\text { Credit Union; Blue Cube Diner (206); Metropolitan } \\
\text { News-Enterprise (210) }\end{array}$ & 23,089 SF; Use Code 1100; Built 1905 \\
\hline None & 130-5A213 82 & 5149007005 & & $\mathrm{C} 2$ & 4D & & & Two Retail/Restaurant Spaces; Offices?, 2 stories? & 12,710 SF; Use Code 1100; Class CX; Narrow Parcel \\
\hline 212-20 S SPRING ST & 130-5A213 83 & 5149007005 & & $\mathrm{C} 2$ & $4 \mathrm{D}$ & & & Two Retail/Restaurant Spaces; Offices?, 2 stories? & 12,710 SF; Use Code 1100 ; Class CX \\
\hline None & $130-5 A 21395$ & 5149007008 & & $\mathrm{C}_{2}$ & 4D & & & Commercial Parking Garage & 175,032 SF; Use Code 2710; Class CX; Built 1970 \\
\hline None & 130-5A213 101 & 5149007008 & & C2 & 4D & & & Commercial Parking Garage & 175,032 SF; Use Code 2710; Class CX; Built 1970 \\
\hline $230-4$ S SPRING ST & 130-5A213 112 & 5149007008 & & $\mathrm{C} 2$ & $4 \mathrm{D}$ & & & Commercial Parking Garage & 175,032 SF; Use Code 2710; Class CX; Built 1970 \\
\hline 236-8 S SPRING ST & 130-5A213 119 & 5149007008 & & $\mathrm{C} 2$ & 4D & & & Commercial Parking Garage & 175,032 SF; Use Code 2710; Class CX; Built 1970 \\
\hline None & 130-5A213 133 & 5149007008 & $\mathrm{a}$ & $\mathrm{C4}$ & 4D & & & Commercial Parking Garage & 175,032 SF; Use Code 2710; Class CX; Built 1970 \\
\hline 244 S SPRING ST & 130-5A213 134 & 5149007001 & $\mathrm{Q}$ & C4 & 4D & & & Parking Lot & Vacant \\
\hline 248 S SPRING ST & 130-5A213 141 & 5149007001 & $\mathrm{a}$ & C4 & 4D & & & Parking Lot & Vacant \\
\hline 252 S SPRING ST/121 W 3RD ST (Stimson) & 130-5A213 149 & 5149007007 & $\mathrm{a}$ & C4 & 4D & & & $\begin{array}{l}\text { Parking Lot, Property of T. D. Stimson (see } \\
\text { Stimson Building, Stimson House) }\end{array}$ & Vacant \\
\hline Done & 130-5A213 37 & 5149008032 & a & C2 & 4D & CDO & & Parking Lot & Vacant; Former site of Ramona Hotel, US Post Office \\
\hline Qone (Spring) & $130-5 A 21359$ & 5149008029 & $\mathrm{a}$ & $\mathrm{C} 2$ & $4 \mathrm{D}$ & CDO & & Times Parking Garage & 471,443 SF; Use Code 2700; Class BX; Built 1988 \\
\hline Qone (Spring) & $130-5 A 21363$ & 5149008029 & $\mathrm{a}$ & $\mathrm{C} 2$ & 4D & CDO & & Times Parking Garage & 471,443 SF; Use Code 2700; Class BX; Built 1988 \\
\hline Eone (spring) & 130-5A21367 & 5149008029 & $\mathrm{Q}$ & $\mathrm{C} 2$ & $4 \mathrm{D}$ & CDO & & Times Parking Garage & 471,443 SF; Use Code 2700; Class BX; Built 1988 \\
\hline Z13 S SPRING ST & 130-5A213 77 & 5149008029 & $\mathrm{a}$ & $\mathrm{C} 2$ & 4D & CDO & & Times Parking Garage & 471,443 SF; Use Code 2700; Class BX; Built 1988 \\
\hline None (Broadway) & $130-5$ A213 42 & 5149008029 & a & $\mathrm{C} 2$ & $4 \mathrm{D}$ & CDO & & Times Parking Garage & 471,443 SF; Use Code 2700; Class BX; Built 1988 \\
\hline None (Broadway) & 130-5A213 48 & 5149008029 & $\mathrm{Q}$ & C2 & $4 \mathrm{D}$ & CDO & & Times Parking Garage & 471,443 SF; Use Code 2700; Class BX; Built 1988 \\
\hline None (Broadway) & 130-5A213 58 & 5149008029 & $\mathrm{a}$ & $\mathrm{C} 2$ & 4D & CDO & & Times Parking Garage & 471,443 SF; Use Code 2700; Class BX; Built 1988 \\
\hline None (Stimson) & 130-5A213 92 & 5149008015 & & $\mathrm{C} 2$ & 4D & & & $\begin{array}{l}\text { Parking Lot, Property of T. D. Stimson (see } \\
\text { Stimson Building, Stimson House) }\end{array}$ & the \\
\hline None & $130-5 A 21399$ & 5149008001 & $\mathrm{a}$ & $\mathrm{C} 4$ & 4D & & & Parking Lot & Vacant \\
\hline 245 S SPRING ST & 130-5A213 102 & 5149008001 & $\mathrm{a}$ & $\mathrm{C4}$ & $4 \mathrm{D}$ & & & Parking Lot & Vacant \\
\hline 257 S SPRING ST/215 W 3RD ST & 130-5A213 202 & 5149008BRK & a & $\mathrm{C} 4$ & 4D & & & $\begin{array}{l}\text { Douglas Building Lofts; Origami Bistro \& Bar (257); } \\
\text { Vacant Commercial Unit? (257, Ste 116); Lot 44 } \\
\text { Coffee \& Gallery (257, Ste 115) }\end{array}$ & $\begin{array}{l}\text { Use Code 010E - Single Residence (Condominium } \\
\text { Conversion); Built } 1898\end{array}$ \\
\hline 200-4 S BROADWAY/232-8 W 2ND ST & 130-5A213 31 & 5149008031 & $\mathrm{a}$ & $\mathrm{C} 2$ & $4 \mathrm{D}$ & CDO & & Parking Lot & Vacant \\
\hline 206-10 S BROADWAY & 130-5A213 34 & 5149008030 & $\mathrm{a}$ & $\mathrm{C} 2$ & $4 \mathrm{D}$ & CDO & & Parking Lot (part of Times Garage?) & Vacant; 8,540 SF; Use Code 2700; Built 1988 \\
\hline 236-40 S BROADWAY & $130-5$ A213 75 & 5149008028 & $\mathrm{Q}$ & C2 & $4 \mathrm{D}$ & CDO & & Parking Lot & Vacant \\
\hline 242-6S BROADWAY & 130-5A213 81 & 5149008009 & $\mathrm{Q}$ & C4 & 4D & CDO & & $\begin{array}{l}\text { Hosfield/Nictor Clothing; Cine-Mex DVD; Basic } \\
\text { Flowers-Gifts-Bridal (244) }\end{array}$ & 41,180 SF; Class AX; 38 Units; Built 1914 \\
\hline 248-60 S BROADWAY $/ 225-35$ W 3RD ST & 130-5A211 80 & 5149008008 & a & C4 & 4D & CDO & & $\begin{array}{l}\text { Carl's Jr./Sbarro; El Pollo Loco; Glamour Antique } \\
\text { Bridal, Tux, Quince (250); Vacant Retail }\end{array}$ & $\begin{array}{l}\text { lo,520 SF; Use Code } 1100 \text { - Stores; Class CX; Built } \\
1898\end{array}$ \\
\hline 312 W 2ND ST & 130-5A213 19 & 5149009019 & & C2 & 4D & & & $\begin{array}{l}\text { LA Law Center; City of LA Parking Violations } \\
\text { Bureau (312) }\end{array}$ & 74,845 SF; Class BXA; Built 1911 \\
\hline Z01-5 S BROADWAY/300 W 2ND ST & 130-5A213 21 & 5149009019 & a & $\mathrm{C} 2$ & $4 \mathrm{D}$ & CDO & & $\begin{array}{l}\text { LA Law Center (205); Vacant Commercial (201, } \\
\text { 203); Redwood Shop Money Orders, Checks } \\
\text { Cashed (304); Prep Xpress (306) }\end{array}$ & 74,845 SF; Class BXA; Built 1911 \\
\hline 207-11 S BROADWAY & 130-5A213 23 & 5149009022 & a & C2 & 4D & CDO & & $\begin{array}{l}\text { LA Law Center (207); Vacant Retail (?) }(209,211) ; \\
\text { Acme Bail (213) }\end{array}$ & 60,998 SF; Class AX; Built 1905 \\
\hline $316-8$ W 2ND ST & 130-5A211 19 & 5149009024 & & $\mathrm{C}_{2}$ & 4D & & & LA Law Center (316); Redwood Bar \& Grill (318) & 76,440 SF; Class BXA; Built 1926 \\
\hline 218-22 S HILL ST & 130-5A211 27 & 5149009023 & & $\mathrm{C} 2$ & $4 \mathrm{D}$ & & MTA & LA Law Center Garage Entrance (222) & 47,330 SF; Class AX; Built 1907 \\
\hline 218-22 S HILL ST & 130-5A211 32 & 5149009021 & & C2 & $4 \mathrm{D}$ & & MTA & 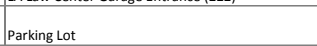 & $\begin{array}{l}\text { Vacant; Use Code } 2700 \text { - Parking Lot (Patron or } \\
\text { Employee); Built } 1953\end{array}$ \\
\hline 213-23 S BROADWAY & 130-5A211 30 & 5149009021 & a & $\mathrm{C} 2$ & 4D & CDO & & Parking Lot & $\begin{array}{l}\text { Vacant; Use Code } 2700 \text { - Parking Lot (Patron or } \\
\text { Employee); Built } 1953\end{array}$ \\
\hline 231-5 S BROADWAY & 130-5A211 37 & 5149009014 & a & C2 & $4 \mathrm{D}$ & CDO & & Parking Lot & $\begin{array}{l}\text { Vacant; Use Code } 2700 \text { - Parking Lot (Patron or } \\
\text { Employee) }\end{array}$ \\
\hline 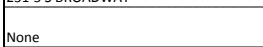 & 130-5A211 43 & 5149009018 & a & $\mathrm{C} 2$ & 4D & CDO & & Goodwill (235) & $\begin{array}{l}27,784 \mathrm{SF} \text {; Class DX; Use Code } 1200 \text { - Store and } \\
\text { Office Combination; Built } 1899\end{array}$ \\
\hline None & $130-5$ A211 33 & 5149009018 & & $\mathrm{C} 2$ & 4D & & MTA & Parking Lot, Rear of Goodwill (5149009018) & $\begin{array}{l}\text { Vacant; } 27,784 \text { SF; Class DX; Use Code } 1200 \text { - Store } \\
\text { and Office Combination; } 1899\end{array}$ \\
\hline $237-41$ S BROADWAY & $130-5 A 21149$ & 5149009004 & $\mathrm{Q}$ & $\mathrm{C} 2$ & $4 \mathrm{D}$ & $\mathrm{CDO}$ & & Guadalupe Wedding Chapel (237) & 10,000 SF; Class C5B; Built 1895 \\
\hline 245 S BROADWAY & 130-5A211 54 & 5149009003 & a & $\mathrm{C} 2$ & 4D & $\mathrm{CDO}$ & & Parking Lot & $\begin{array}{l}\text { Vacant; Use Code } 2700 \text { - Parking Lot (Patron or } \\
\text { Employee); Built } 1962\end{array}$ \\
\hline 249-59 S BROADWAY & 130-5A211 207 & \$149009BRK & $a$ & $\mathrm{C} 2$ & $4 \mathrm{D}$ & $\mathrm{CDO}$ & & Pan-American Lofts & 6,640 SF (?); Class BX; Built 1897 \\
\hline 200-10 S HILL ST/320-30 W 2ND ST & 130-5A211 17 & 5149009017 & & C2 & 4D & & MTA & $\begin{array}{l}\text { Kawada Hotel; Vacant (326?); Pho Citi (200); } \\
\text { Cherry Pick Café (208) }\end{array}$ & 52,620 SF; Class CX; Built 1923 \\
\hline 212 S HILL ST & 130-5A211 23 & 5149009016 & & C2 & 4D & & MTA & Parking Lot & $\begin{array}{l}\text { Vacant; Use Code } 2700 \text { - Parking Lot (Patron or } \\
\text { Employee); Built } 1982\end{array}$ \\
\hline 228-34 S HILL ST & 130-5A211 29 & 5149009014 & & $\mathrm{C} 2$ & 4D & & MTA & Parking Lot & $\begin{array}{l}\text { Vacant; Use Code } 2700 \text { - Parking Lot (Patron or } \\
\text { Employee) }\end{array}$ \\
\hline $236-40$ S HILL ST & 130-5A211 36 & 5149009011 & & $\mathrm{C} 2$ & 4D & & MTA & Parking Lot & $\begin{array}{l}\text { Vacant; Use Code } 2710 \text { - Parking Lot (Commercial); } \\
\text { Built } 1992\end{array}$ \\
\hline 246-8 S HILL ST & 130-5A211 45 & 5149009025 & & $\mathrm{C} 2$ & 4D & & MTA & Parking Lot & $\begin{array}{l}\text { Vacant; Use Code } 2700 \text { - Parking Lot (Patron or } \\
\text { Employee); Built } 1981\end{array}$ \\
\hline 250-62 S HILL ST & 130-5A211 46 & 5149009009 & & C2 & 4D & & MTA & Parking Lot & $\begin{array}{l}\text { Vacant; Use Code } 2700 \text { - Parking Lot (Patron or } \\
\text { Employee); Built } 1941\end{array}$ \\
\hline $315-9$ W 3RD ST & 130-5A211 56 & 5149009008 & & C2 & 4D & & & Parking Lot & $\begin{array}{l}\text { Vacant; Use Code } 2700 \text { - Parking Lot (Patron or } \\
\text { Employee); Built } 1941\end{array}$ \\
\hline 311-3 W 3RD ST & 130-5A211 59 & 5149009001 & & $\mathrm{C} 2$ & 4D & & & Parking Lot & $\begin{array}{l}\text { Vacant; Use Code } 2700 \text { - Parking Lot (Patron or } \\
\text { Employee); Built } 1939\end{array}$ \\
\hline
\end{tabular}

